U.S. Department of Interior

U.S. Geological Survey

In Cooperation with the Town of Rye, New Hampshire

\title{
Borehole-Geophysical Characterization of a Fractured-Bedrock Aquifer, Rye, New Hampshire
}

By Carole D. Johnson, Alicia H. Dunstan, Thomas J. Mack, and John W. Lane, Jr.

Open-File Report 98-558

Pembroke, New Hampshire 


\title{
U.S. DEPARTMENT OF THE INTERIOR \\ BRUCE BABBITT, Secretary
}

\author{
U.S. GEOLOGICAL SURVEY \\ Charles G. Groat, Director
}

The use of firm, trade, and brand names in this report is for identification purposes only and does not constitute endorsement by the U.S. Geological Survey.

For additional information write to:

\section{District Chief}

U.S. Geological Survey

New Hampshire/Vermont District

361 Commerce Way

Pembroke, NH 03275-3718
Copies of this report can be purchased from:
U.S. Geological Survey
Branch of Information Services
Box 25286, Federal Center
Denver, CO 80225 


\section{CONTENTS}

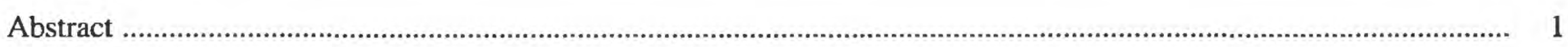

Introduction

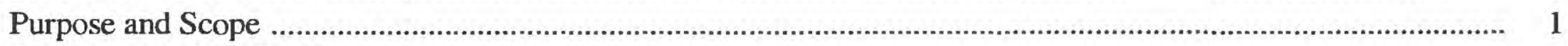

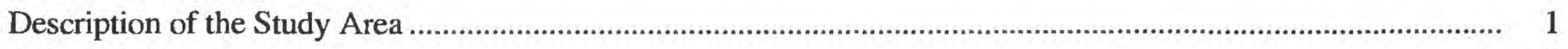

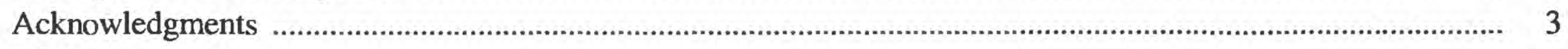

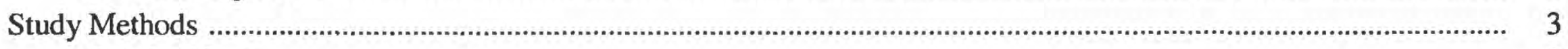

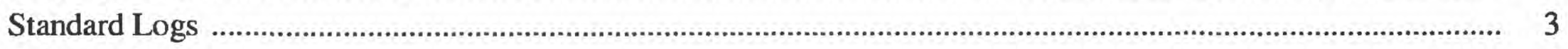

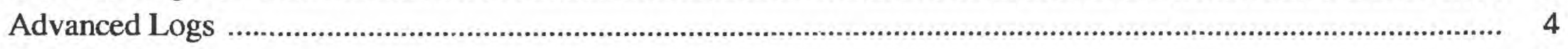

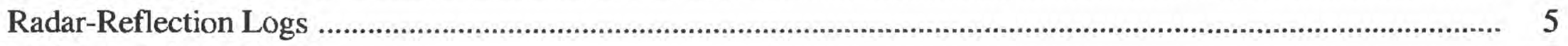

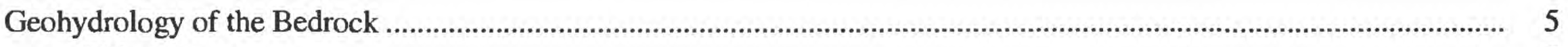

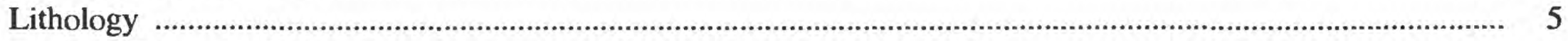

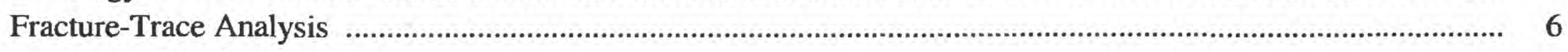

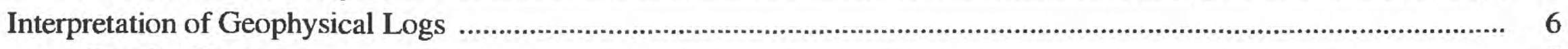

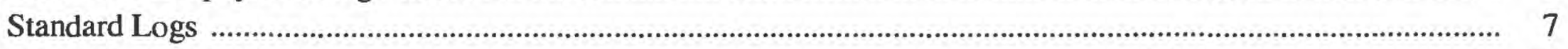

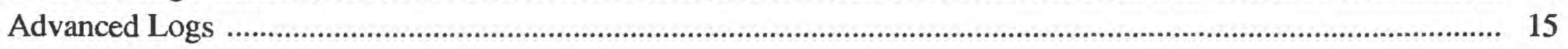

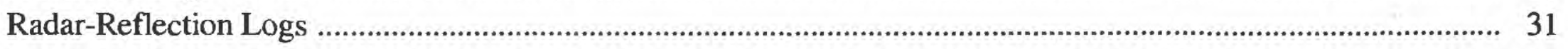

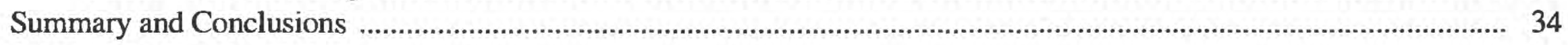

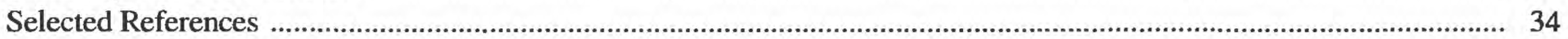

Appendix 1. Acoustic Televiewer Logs of Wells in Rye, New Hampshire .......................................................... 37

\section{FIGURES}

1. Map showing location of the study area and photolinear data in Rye, New Hampshire...................................... 2

2. Graph showing acoustic televiewer (ATV) log of well TBR-2 ….............................................................. 5

3-8. Graphs showing geophysical logs of well:
3. TBR-1
4. TBR-2
5. TBR-3
6. W-3
7. $W-4$
8. W-5

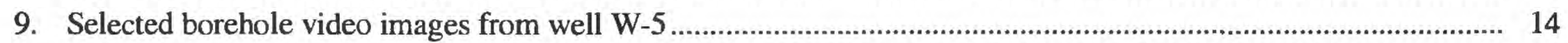

10. Diagrams showing deviation logs of wells TBR-1, TBR-2, TBR-3, W3, W4, and W5 ..................................... 16

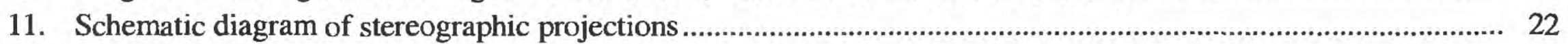

12-17. Diagrams showing locations and orientations of fractures observed in acoustic televiewer (ATV) logs of well:

12. TBR-1

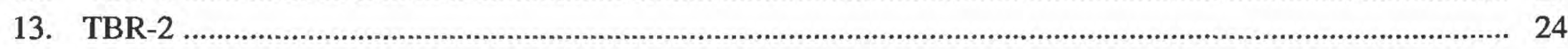

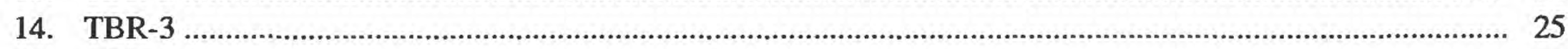

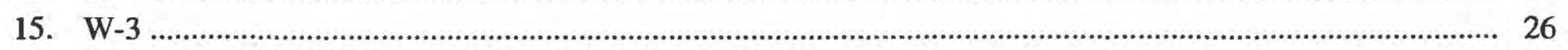

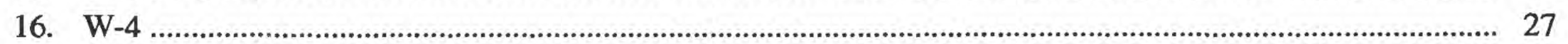

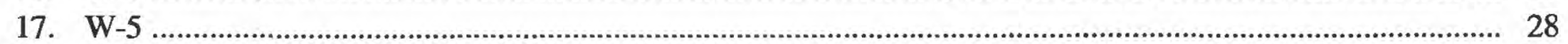

18-20. Graphs showing:

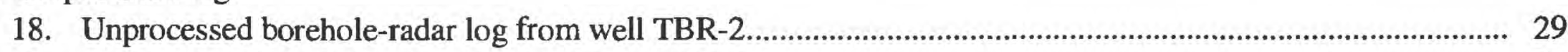

19. Unprocessed borehole-radar log from well TBR-3 ........................................................................ 31

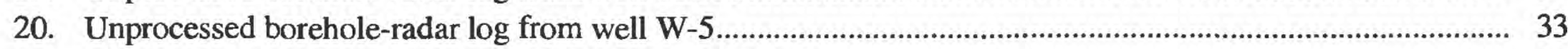

21. Stereogram of radar reflectors from wells TBR-2 and TBR-3 ..................................................................... 33 


\section{TABLES}

1. Midpoint depth, strike, and dip of fractures identified in wells TBR-1, TBR-2, TBR-3, W-3, W-4, and W-5, by acoustic televiewer in Rye, New Hampshire

2. Statistical summary of fracture type and orientations for wells TBR-1, TBR-2, TBR-3, W-3, W-4, and W-5 ....... 30

3. Projected midpoint depth, strike and dip of reflectors identified by borehole radar for wells TBR-2, TBR-3, and W-5

CONVERSION FACTORS, VERTICAL DATUM, AND ABBREVIATIONS

\begin{tabular}{rll}
\hline Multiply & \multicolumn{1}{c}{ By } & To obtain \\
\hline inch (in.) & 25.4 & millimeter \\
foot (ft) & 0.3048 & meter \\
meter (m) & 3.281 & foot \\
gallon per minute (gal/min) & 0.00006309 & cubic meter per second \\
Temperature in degrees Fahrenheit $\left({ }^{\circ} \mathrm{F}\right)$ can be converted to degrees Celsius $\left({ }^{\circ} \mathrm{C}\right)$ as follows: \\
\\
${ }^{\circ} \mathrm{C}=5 / 9\left({ }^{\circ} \mathrm{F}-32\right)$.
\end{tabular}

Sea Level: In this report "sea level" refers to the National Geodetic Vertical Datum of 1929 (NGVD of 1929)a geodetic datum derived from a general adjustment of the first-order level nets of both the United States and Canada, formerly called Sea Level Datum of 1929.

\section{OTHER ABBREVIATIONS USED IN THIS REPORT:}

$\mathrm{dB} / \mathrm{m} \quad$ decibels per meter

$\mathrm{MHz} \quad$ megahertz

$\mathrm{m} / \mathrm{\mu s} \quad$ meters per microsecond

OHM-m ohms-meter

$\mu \mathrm{S} / \mathrm{cm} \quad$ microsiemens per centimeter 


\title{
Borehole-Geophysical Characterization of a Fractured-Bedrock Aquifer, Rye, New Hampshire
}

\author{
By Carole D. Johnson, Alicia H. Dunstan, Thomas J. Mack, and John W. Lane, Jr.
}

\section{Abstract}

Borehole geophysical logs collected from six wells were analyzed to characterize a highyield bedrock aquifer in the Town of Rye, New Hampshire. Video camera, caliper, fluid temperature and conductivity, natural gamma, and deviation logs were used to identify and characterize the fractured bedrock. More advanced geophysical tools included acoustic televiewer and borehole radar, which were used to determine the orientation of fractures and fracture zones that intersect and surround each of the six wells. Borehole-radar surveys included single-hole directional-reflection surveys. The boreholeradar logs indicate that the bedrock aquifer is highly fractured. Zones of low velocity and high attenuation in the radar logs correlated with the fractures and fracture zones observed in the standard geophysical logs of the six wells. The strikes of the fracture sets, as determined by the acoustic televiewer, coincide with photolineaments identified on high-altitude and low-altitude aerial photography and side-looking airborne radar (SLAR). The coincident fracture sets and lineaments trend $\mathrm{N} 100^{\circ} \mathrm{E}, \mathrm{N} 140^{\circ} \mathrm{E}, \mathrm{N} 170^{\circ} \mathrm{E}$, and $\mathrm{N} 40^{\circ} \mathrm{E}$.

\section{INTRODUCTION}

Many towns and communities in New Hampshire have limited amounts or an absence of sand and gravel aquifers, which are favorable for constructing high-yield wells. These towns must look for additional water resources in crystalline bedrock, which generally yields very small quantities (a few gallons per minute) of water to wells. A number of bedrock wells constructed in the Grove Road area in Rye, N.H., yield more than $100 \mathrm{gal} / \mathrm{min}$. Information on the hydraulic characteristics of the fractured bedrock aquifer in this area, including the primary flow pathways to the wells, is needed to protect this water resource and to identify those characteristics that may be useful in locating other high-yield wells in fractured bedrock aquifers. The U.S. Geological Survey (USGS), in cooperation with the Town of Rye, in southeastern N.H. (fig. 1), used geophysical methods to characterize hydraulic properties in six wells and to determine the nature of fractures in the high-yield bedrock aquifer.

\section{Purpose and Scope}

The purpose of this report is to demonstrate how advanced borehole geophysical techniques, in combination with remotely sensed lineament analysis, are applied and used to characterize a fractured bedrock aquifer underlying Rye, N.H. The results of the study are the interpretation of the location, nature, and extent of fractures in a bedrock aquifer. Geophysical logs collected from six boreholes are presented and interpreted in order to characterize the bedrock aquifer.

\section{Description of the Study Area}

The study area consists of a bedrock aquifer off Garland Road in the southeastern corner of the Town of Rye, N.H. (fig. 1). Test wells in this bedrock aquifer are 323 to $550 \mathrm{ft}$ deep, and are 6- and 8-in. in diameter. There are two well fields in the study area - the Bailey Brook well field and the Cedar Run well field. Three bedrock wells (W-3, W-4, W-5) are 


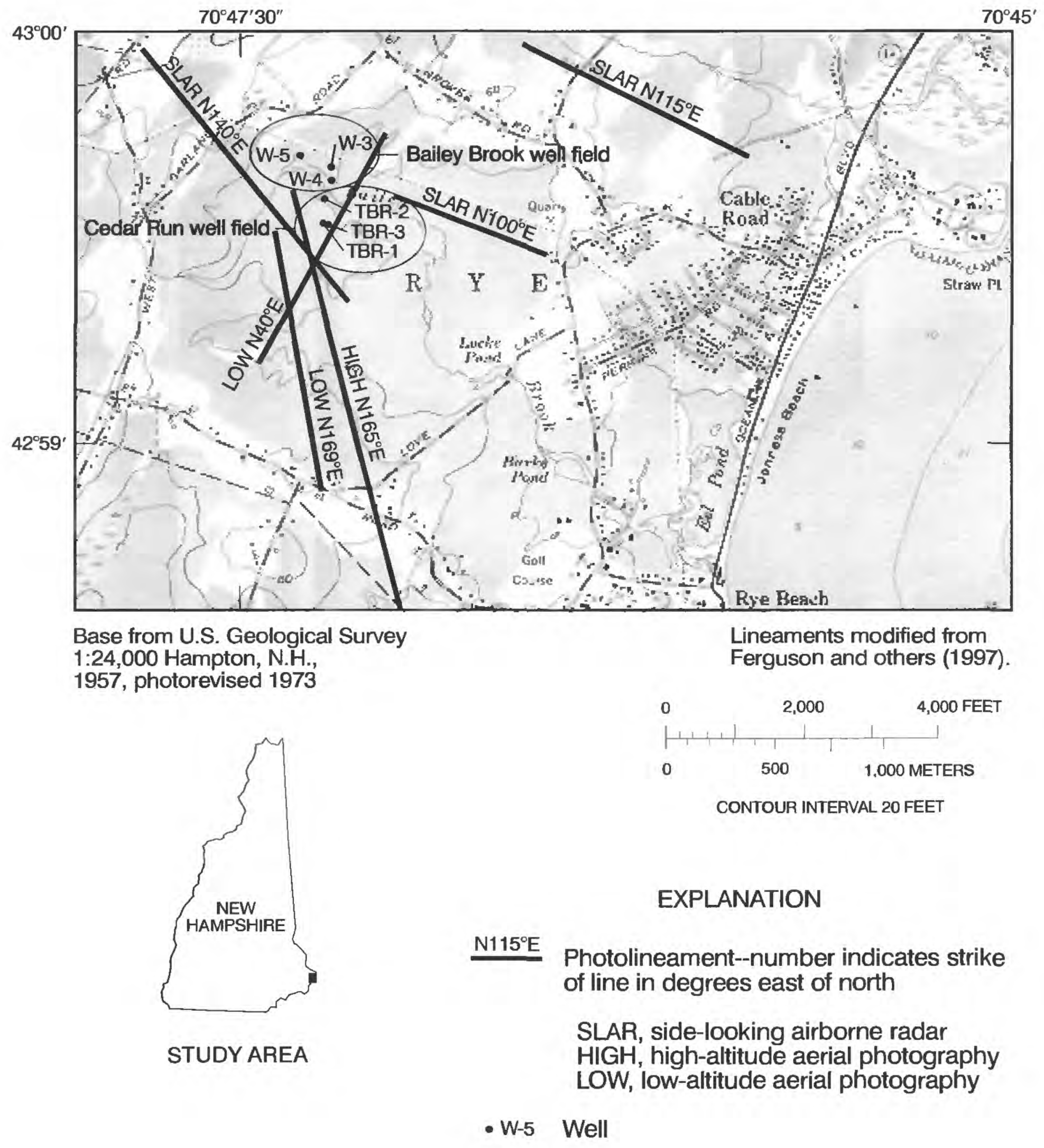

Figure 1. Locations of study area and photolinear data in Rye, New Hampshire. 
adjacent to Bailey Brook and the Bailey Brook municipal-supply well (fig. 1). Three other wells are located about $900 \mathrm{ft}$ south of the Bailey Brook well, in the Cedar Run well field, an area suspected to be at the junction of numerous lineaments (D.L. Maher, 1982) and, therefore, the focus of this investigation. Bedrock wells in the Cedar Run well field include TBR-2, adjacent to Bailey Brook, TBR-1, and TBR-3, which is about $12 \mathrm{ft}$ east of TBR-1 (D.L. Maher, 1982). The Cedar Run field is overlain by glacial till, which ranges in thickness from $0-25 \mathrm{ft}$. The till consists of compact unsorted sand, silt, clay, and rocks. The Cedar Run municipal well, drilled after the field effort of this study, was completed to a depth of $437 \mathrm{ft}$ and yields greater than $350 \mathrm{gal} / \mathrm{min}$. (Reidar Bomengen, D.L. Maher, written commun., 1998).

\section{Acknowledgments}

Appreciation is expressed to officials and employees of the Rye Water District who provided assistance and access to their wells. Special thanks are extended to Gary Smith, of D.L. Maher, Inc., for providing assistance and insight throughout the investigation regarding wells, fracture-trace analysis, and the bedrock aquifer in Rye.

\section{STUDY METHODS}

Borehole geophysical logs were used to characterize the geohydrology of the fractured bedrock aquifer. The borehole logs collected in wells TBR-1, TBR-2, TBR-3, W-3, W-4, and W-5 included a standard suite of geophysical logs such as video camera, caliper, fluid temperature and resistivity, and natural gamma. More advanced geophysical logs that were collected include acoustic televiewer (ATV) and deviation. Heat-pulse flowmeter data were collected in TBR-3. Single-hole-directional radar-reflection surveys were collected in TBR-2, TBR-3, W-3, W-4, and W-5. In all geophysical logs, depth measurements are referenced to the top of the steel well casing.

\section{Standard Logs}

A submersible color video camera was used to examine the wells to discern rock types, fractures, possible faults, and the condition or integrity of the well. The camera had a digital depth counter, which was incremented in tenths of feet and was superimposed onto the analog picture. Continuous images were recorded on video cassettes. The locations of fractures and rock types were identified directly from the images and were tabulated and plotted. The fractures were described with a code that indicates if it appears to be (1) a "major fracture," (2) a "fracture," or (3) a "possible fracture." The term "major fracture" was used to describe an open fracture that exhibits a wide aperture and (or) oxidation or alteration of the adjacent rock. A fracture without a wide aperture or oxidation was coded simply as "fracture." The term "possible fracture" was assigned to features that appeared as dark-lines in the borehole images and could potentially be fractures. However, it is not always possible to verify the presence of a fracture by visual inspection. Techniques and equipment for borehole imaging used for the well surveys are described by Johnson (1996) and Johnson and Dunstan (1998). Video logs were collected in all of the wells. However, only the upper $291 \mathrm{ft}$ were logged in TBR-1 because below that depth, the water was murky and the view of the borehole was obscured. TBR-3 was logged to a depth of $208 \mathrm{ft}$, where there was an obstruction.

The caliper log was used to generate a continuous profile of the borehole diameter. This log shows the mechanical measurement as a spring-loaded, threearm caliper tool is pulled up the well. The arms open as they pass borehole enlargements. Enlargements in the borehole diameter generally are related to fractures, but can also be caused by changes in lithology or well construction. The profile indicates the roughness of the borehole wall. Some enlargements may be larger than the caliper diameter, which is $18 \mathrm{in}$.

The fluid temperature log displays a continuous measurement of the temperature of fluid in the borehole. In the absence of ground-water flow, the temperature gradually increases with the geothermal gradient, which is $0.6^{\circ} \mathrm{C}$ per $100 \mathrm{ft}$ of depth (Keyes, 1988). A continuous plot of the fluid temperature with depth is used to identify zones that deviate from the expected geothermal gradient. Deviations from the gradient indicate locations where ground water enters or exits the borehole.

The fluid-resistivity log records the electrical resistance of the fluid in the borehole. Changes in the electrical resistance of the water in the borehole 
indicate differences in the concentration of the total dissolved solids in the water in the borehole. These differences typically indicate sources of water that have contrasting chemistry and have come from alternate water-bearing zones. Fluid conductivity is computed as the reciprocal of the fluid resistivity.

The gamma log measures the natural-gamma radioactivity of the formation surrounding the borehole. Gamma radiation is a natural product of the radioactive decay of potassium- 40 , and a daughter product of uranium and thorium decay. The gamma log used in this investigation does not differentiate between the sources of the gamma radiation. It counts the total gamma-radiation emissions, which can often be correlated with the rock type or with fracture infillings. Potassium -40 is abundant in potassium feldspar (microcline and orthoclase), which alters to sericite and clay. In the alteration process, potassium- 40 is concentrated in the clay by processes of adsorption and ion exchange. Deviations in the gamma log trace indicate changes in the rock type or the presence of mineralized fractures. Clay minerals, which sometimes comprise the infilling of fractures, generally have an elevated concentration of potassium -40 minerals and cause an increase in the gamma log. Mafic dikes are devoid of gamma emitters and have a low gamma signature.

\section{Advanced Logs}

A flowmeter measures the velocity of vertical flow in the borehole. Used in conjunction with the other geophysical logs, individual fractures or zones of fractures can be identified as the locations where water enters or exits the borehole. Under ambient conditions, differences in hydraulic heads between two water-bearing zones produce vertical flow in the well. The water enters the borehole from the waterbearing zone with the higher head and flows towards and out of the zone with lower head. The flowmeter used in this investigation makes use of a heat-pulse tracer rather than the more conventional impeller method described by Paillet and Williams (1992). The heat-pulse flowmeter uses a thermal tracer to measure flows as small as $0.01 \mathrm{gal} / \mathrm{min}$ (Hess and Paillet, 1990). The measurements are collected at discrete locations, usually above and below fractures.
Boreholes drilled into crystalline rock frequently deviate from vertical due to variations in rock properties, the fabric of the bedrock, or the presence of fracturing. In addition, the deviation of the borehole may be enhanced by drilling techniques. The deviation log records the azimuthal direction $\left(0-360^{\circ}\right)$ and the inclination $\left(0-90^{\circ}\right)$ of the borehole over the depth of the borehole. This log is used to correct the orientation of fractures determined from the acoustic televiewer (ATV) logs.

The ATV was used to map the location and orientation of fractures that intersect a well. The ATV tool emits a narrow acoustic beam that rotates $360^{\circ}$ and is focused at the solid borehole wall. The acoustic wave moves through the fluid in the borehole and is reflected off the borehole wall. The log records the amplitude and travel time of the reflected signal (fig. 2) The product is a high-resolution, digital image, oriented to magnetic north, that can be used to determine the location and orientation (strike and dip) of fractures and some lithologic contacts. The travel time can be displayed in the form of an acoustic caliper log that shows the oriented cross-sectional dimensions of the borehole. A fracture that intersects the borehole causes the impedance and scattering of the acoustic wave and a low amplitude response of the signal. The amplitude of the reflected acoustic signal of a smooth and intact borehole wall is higher than the signal response of a rough or fractured borehole wall. A segment of the ATV data collected in well TBR-2 is shown in figure 2. A fracture appears on the image as a high contrast, low amplitude line (dark bands in fig. 2). On the acoustic caliper log, a fracture is indicated by an increase in the one-way travel time of the wave, which is converted to a borehole diameter (fig. 2). Borehole diameter is shown in two directions, north to south and east to west. The trace of the northsouth caliper log has been reversed and decreases from 18 to 2 in., whereas the east-to-west caliper trace extends from 2 to $18 \mathrm{in}$. In this form, the two adjacent plots give the appearance of a cross section of the well diameter. 


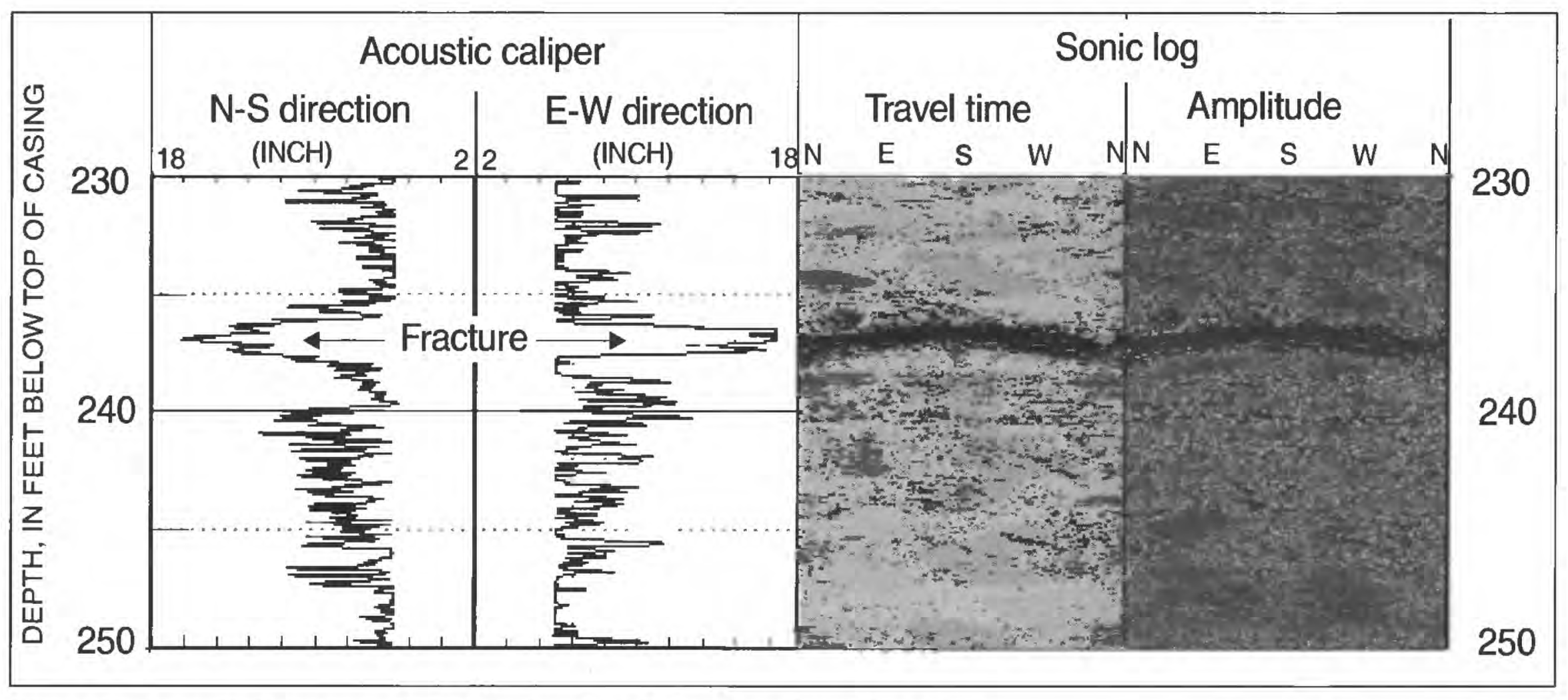

Figure 2. Acoustic televiewer (ATV) log of well TBR-2 in Rye, New Hampshire.

\section{Radar-Reflection Surveys}

Borehole-radar surveys were conducted to determine the orientation and location of discrete fractures or fracture zones surrounding the borehole. Following the methods of Lane and others (1994), single-hole directional surveys were conducted in wells TBR-2, TBR-3, W-3, W-4, and W-5. The directional antenna is used to determine the strike and dip of the reflectors surrounding the borehole. The two antennas used in this investigation were a broadbased electric-dipole transmitting antenna with a center frequency of $22 \mathrm{MHz}$ and a $60-\mathrm{MHz}$ directional-receiving antenna. The transmitting and receiving antennas were separated by a distance of $21 \mathrm{ft}$.

Borehole-radar logs were used to determine the location and lateral extent of fractures in the bedrock surrounding the borehole. A transmitting antenna radiates pulses of electromagnetic energy that propagate from the borehole into the surrounding rock. Point or planar reflectors at interfaces between two electromagnetically different materials can be identified in the log. Reflections are caused by water-filled fractures, faults, bedding, changes in rock type, or water quality (Lane and others, 1994). The electromagnetic waves continue to propagate and be reflected until all of the energy is dissipated. The total distance of penetration away from the borehole depends on the frequency, arrangement of the transmitting and receiving antennas, and the electromagnetic properties of the rock. Under ideal conditions, the radar can "see" into the surrounding rock up to radial distances of 100 or more feet.

\section{GEOHYDROLOGY OF THE BEDROCK}

\section{Lithology}

The rocks that underlie the Rye well fields are folded, fractured, metasedimentary rocks of the Ordovician (?) age to Late Proterozoic (?) Rye Complex (Lyons and others, 1997). Tectonic compressional events in the Paleozoic age caused deformation of the crystalline rock. Major faults (including the Portsmouth Fault and Great Common Fault) and small scale faulting are mapped to the west and north of the study area (Novotny, 1969; Brooks, 1986; Brooks and Rickerich, 1996; Hussey and Bothner, 1993). Brooks (1986) summarized the prominent structural fabrics of the seacoast region. Joints and faults in the Rye Complex were reported to trend $0^{\circ}, 40-45^{\circ}, 60-70^{\circ}, 90^{\circ}, 305^{\circ}$, and $340^{\circ}$ east of north, and strike-slip faults in the Rye Complex trend $\mathrm{N} 40^{\circ} \mathrm{E}$ and $\mathrm{N} 60-80^{\circ} \mathrm{E}$. 
The lower member of the Rye Complex consists of light-colored to gray schists, quartzites, and gneisses (Novotny, 1969) and is distinguished from the upper member by a predominance of lightcolored minerals such as plagioclase, feldspar, and quartz. The upper and lower members are coarse grained and distinctly banded. The Rye Complex has been intruded by many younger intrusive granitic and diabase structures (Novotny, 1969).

Most of the rocks encountered in the wells were metasedimentary rocks, including schist and gneiss with lesser amounts of quartzite and basalt. Drill cuttings from a production well (Cedar Run well) drilled in 1997 are described (Kevin Trainer, University of New Hampshire, written commun. to Town of Rye, 1997) as five rock types including (1) gray quartz-feldspar-muscovite schist; (2) gray quartz-feldspar-biotite-muscovite-garnet schist; (3) dark gray basalt; (4) dark gray quartz; and (5) light gray quartz-feldspar-muscovite-biotite gneiss granite.

\section{Fracture-Trace Analysis}

A fracture-trace analysis of bedrock in the study area was performed by the USGS as part of a statewide bedrock aquifer-mapping assessment (Moore and Clark, 1995; Ferguson and other, 1997). Fracture-trace analysis identifies straight-line features on the land surface, as viewed on multiple platforms of remotely-sensed images, that are most likely related to the surface expression of steeply dipping fractures or fracture zones. These linear features, or lineaments, are noted by the detection of narrow troughs in the topography, truncated geomorphic features, gaps in ridges, straight-line stream segments, and (or) variations in the vegetation or soil. This method provides trend of the linear feature, but does not provide a measurement of dip angle. If the land surface is flat, then dipping beds can appear as linear features on remotely-sensed images. Any relief on the land surface causes non-vertical features to appear as curvilinear features on remotely-sensed images.

The methods and criteria of the statewide fracture-trace analysis are described by Clark and others (1996). The technique used by the statewide analysis requires the identification of lineaments by two independent observers on multiple scales and types of imagery including black and white aerial photography (at a scale of 1:20,000 and 1:80,000), side-looking airborne radar (SLAR) (at a scale of 1:250,000) and Landsat (at a scale of 1:1,000,000).

Lineaments identified at or near the study area by Ferguson and others (1997) are shown in figure 1. A low-altitude $(1: 20,000)$ lineament $\left(\mathrm{N} 40^{\circ} \mathrm{E}\right)$ intersects the study area, near TBR-3, and was also noted by a previous investigation (D.L. Maher, 1982). Upstream of the well field, Bailey Brook follows a trend that parallels the low-altitude lineament with a trend of $\mathrm{N} 40^{\circ} \mathrm{E}$, which correlates to one of the dominant joint trends (Brooks, 1986). The brook bends abruptly near W-5 and follows the trend of a SLAR lineament bearing $\mathrm{N} 100^{\circ} \mathrm{E}$. This trend $\left(\mathrm{N} 100^{\circ} \mathrm{E}\right)$ is close to dominant joint sets of $N 90^{\circ} \mathrm{E}$ and $\mathrm{N} 290^{\circ}$, reported by Brooks (1986). In addition, there is a SLAR lineament, northeast of the well field, that trends $\mathrm{N} 115^{\circ} \mathrm{E}$. The lineaments trending $\mathrm{N} 169^{\circ} \mathrm{E}$ and $\mathrm{N} 165^{\circ} \mathrm{E}$ that are mapped in the study area have a similar trend $\left(\mathrm{N} 340^{\circ} \mathrm{E}\right)$ to a dominant joint set mapped in the Rye Formation (Brooks, 1986).

Although Clark and others (1996) used a standardized process and criteria for lineament mapping, the technique can be somewhat subjective. Depending on the platform scale observed, and the methods and criteria used, additional or different patterns of lineaments could be mapped for the study area. For example, some of the same lineaments were identified in a previous study by D.L. Maher, Inc. (1982, fig. 3). The earlier study, however, also identified numerous lineaments with orientations other than those shown on figure 1. A site-specific study, such as that done by D.L. Maher, Inc., is likely to be concerned with finding all possible lineaments, rather than more selectively identifying lineaments following the consistent criteria used by Clark and others (1996).

\section{INTERPRETATION OF GEOPHYSICAL LOGS}

Borehole-radar logs were completed in February 1997. Other logs were collected in February and March of 1997. The geophysical logs were examined to identify anomalies or changes in the measured properties that relate to locations of fractures or lithologic contacts. Borehole video, ATV, and radar data are either not shown, or only a segment is shown, in this report. (Original data are maintained on file in the New Hampshire/Vermont District office.) 
-sarmpexy

8ิน!ฺ

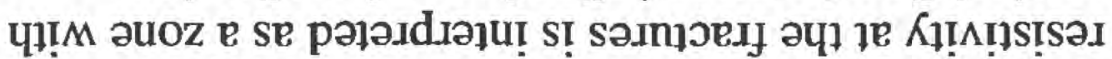

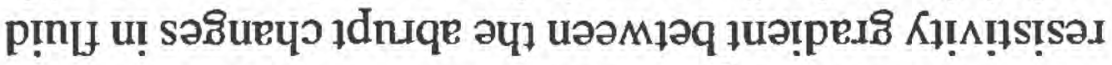

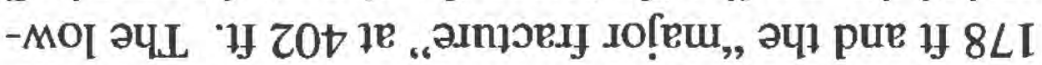

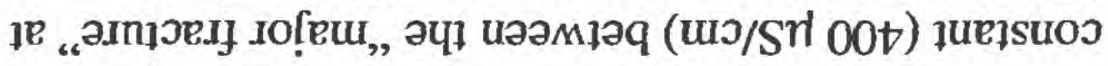

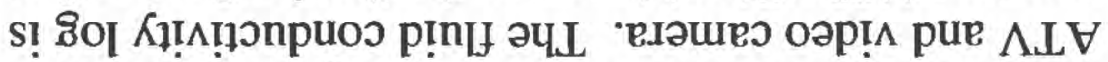

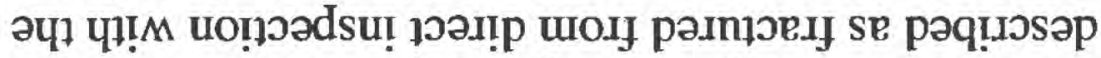

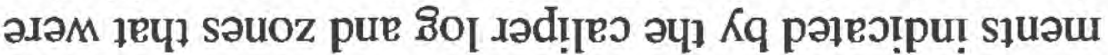

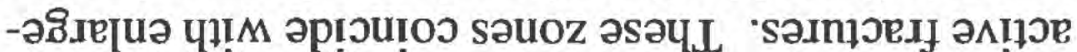

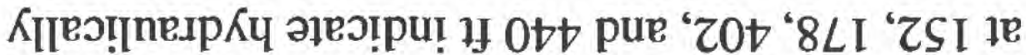
8ิ이 K!!

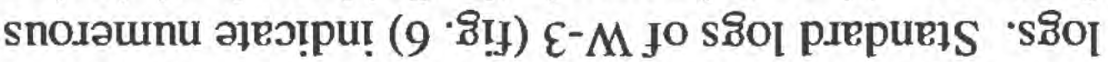

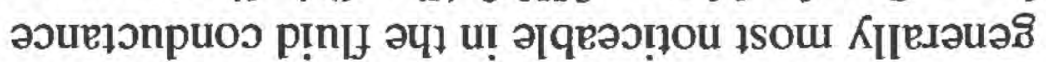

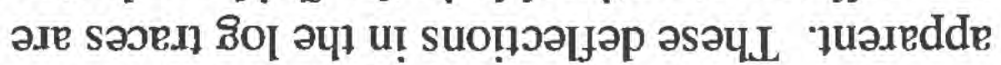

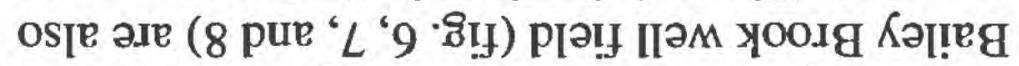

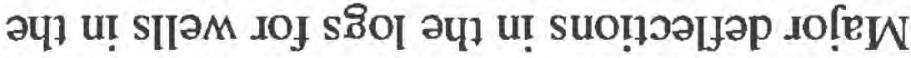

'I $08 \varepsilon$ pue 'cIZ

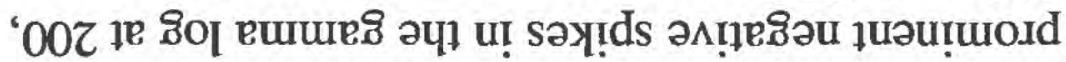

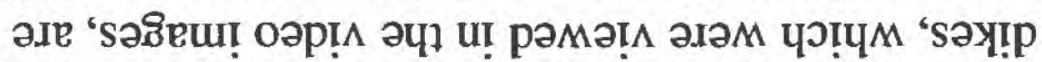
¡[

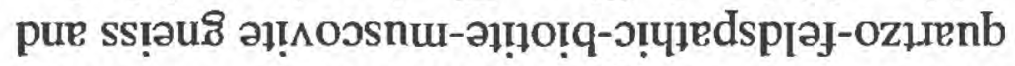

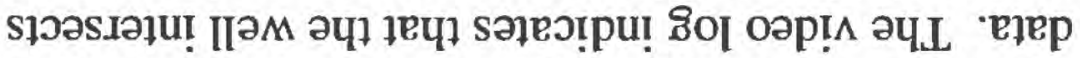

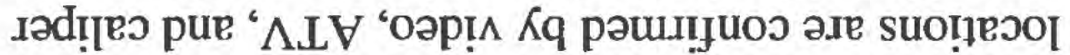

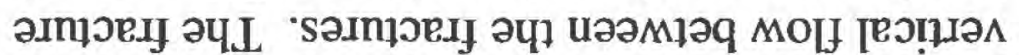
फा!M II

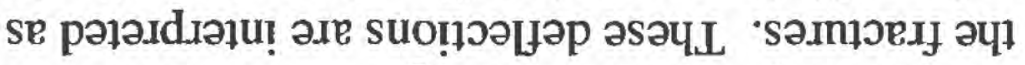

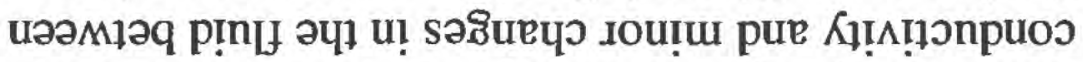

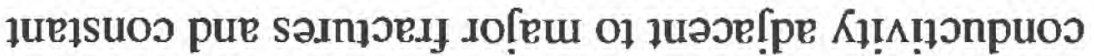

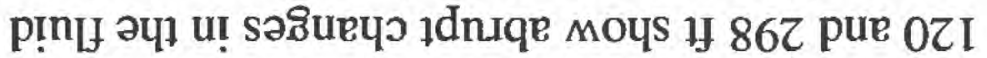

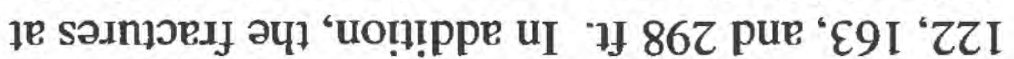

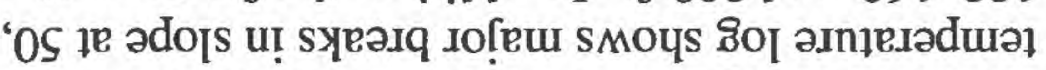

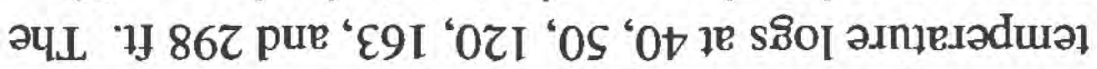

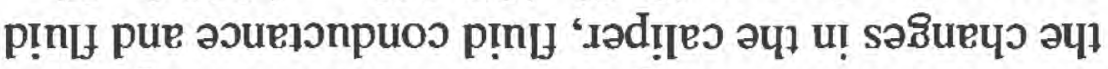

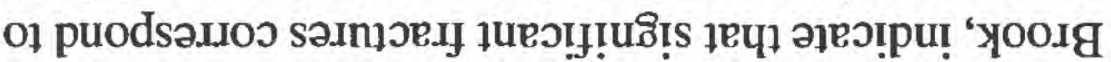

Кәџเе

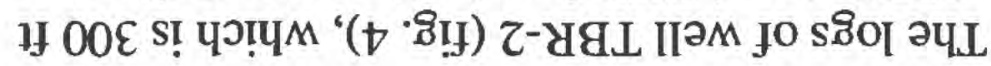

uo!̣วantp

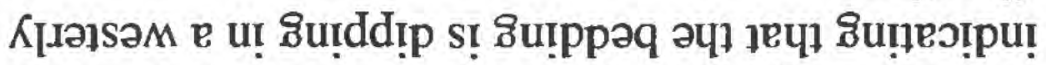

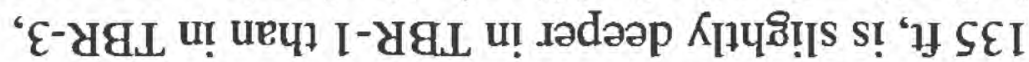

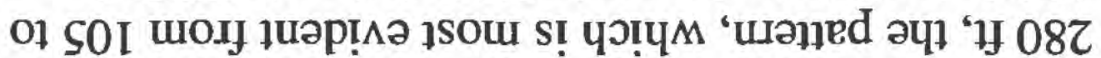
pue $0 \varepsilon$ uәəм]əg '

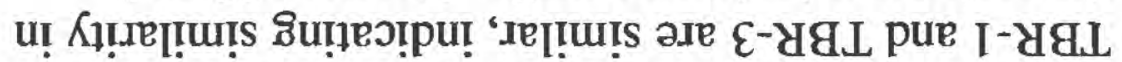

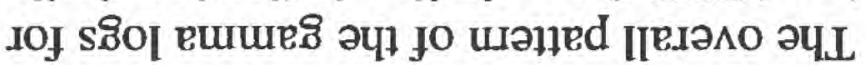

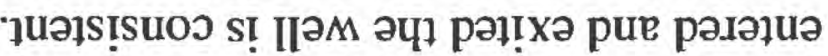

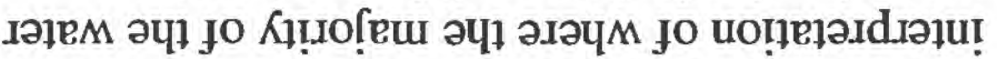

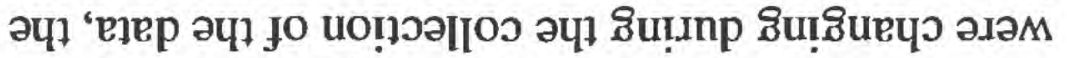

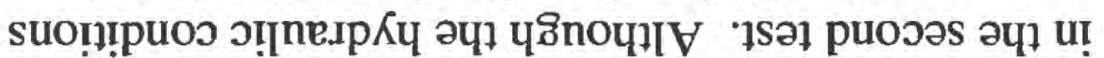
Ұ 09 1

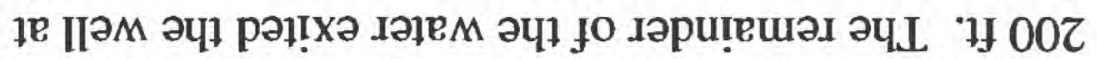

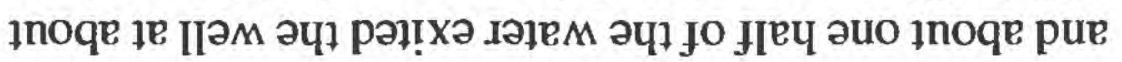

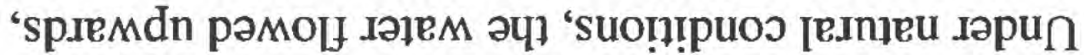

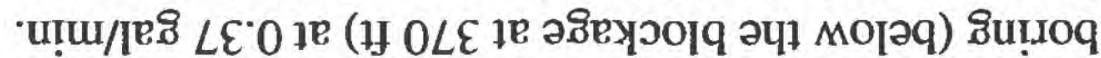

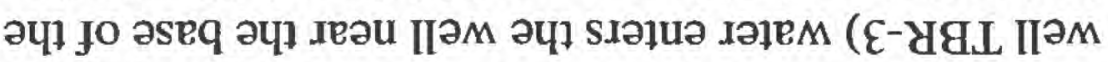
u! ә8̊ duund ou) suo!!!

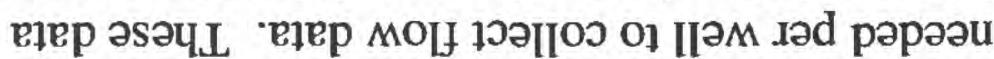

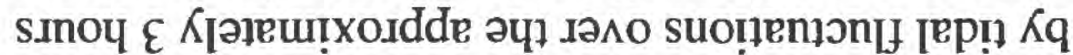

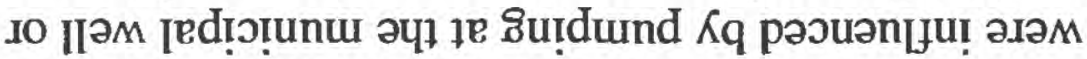

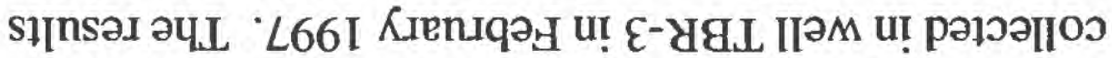

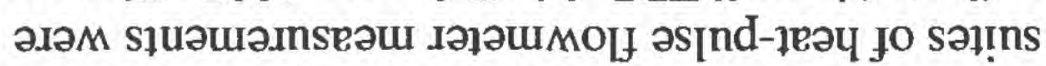

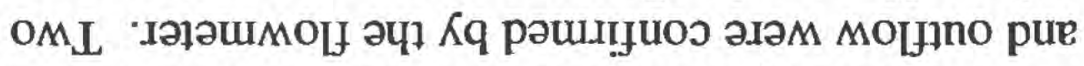
моцرu! p!n

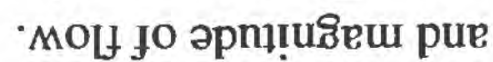

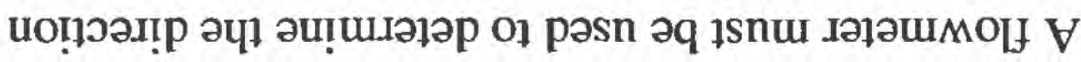

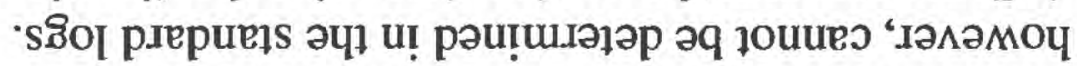

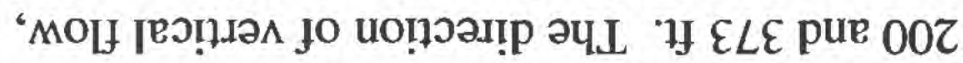

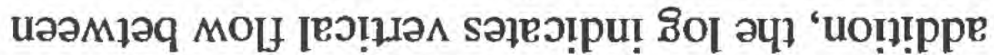

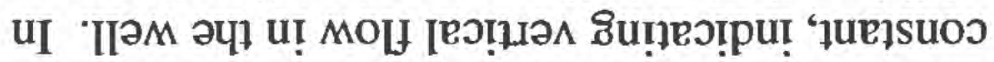

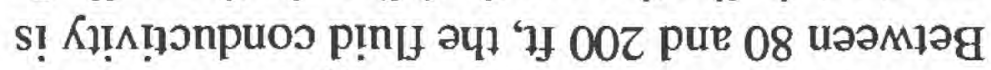

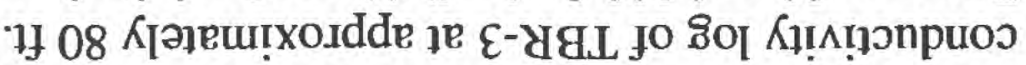
p!n

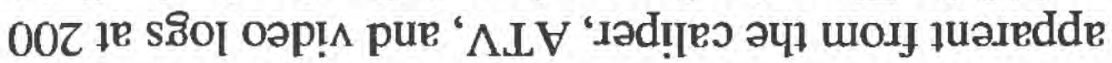

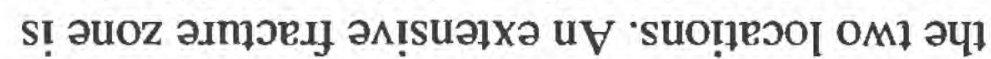

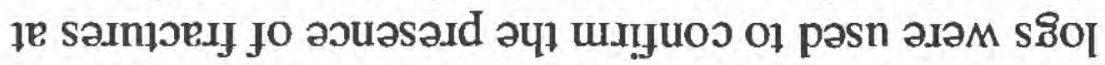

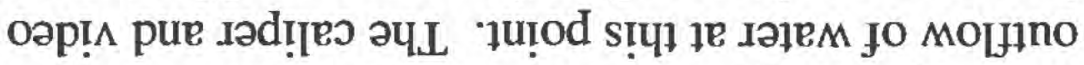

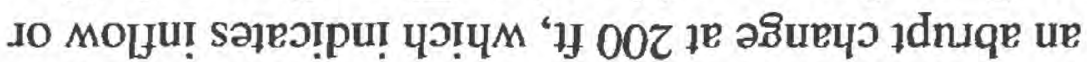

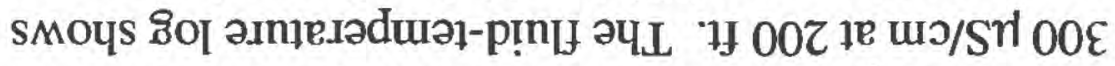

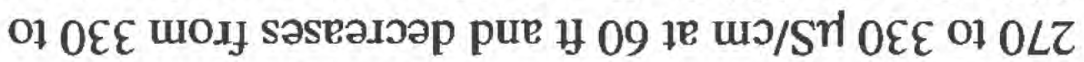

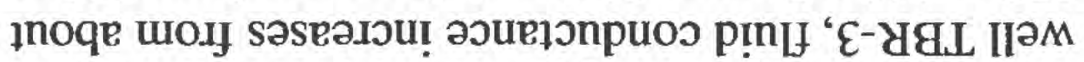

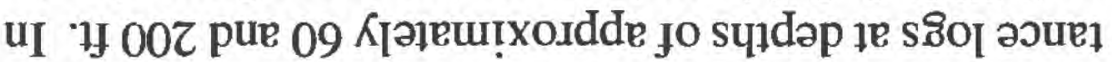

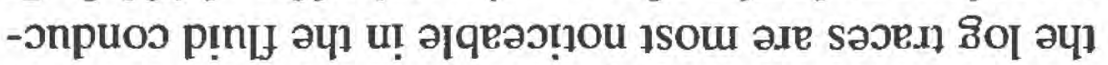

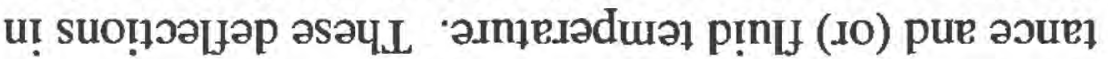

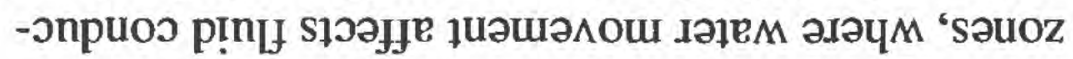

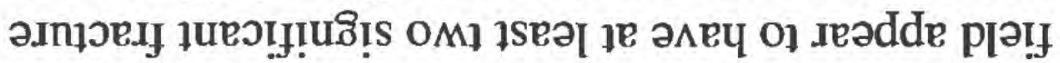

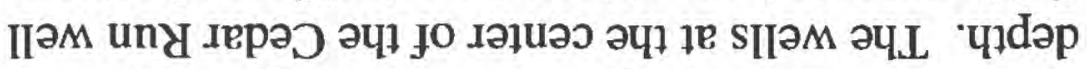

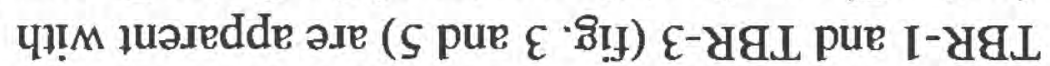

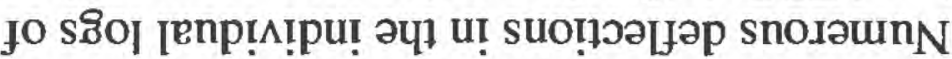

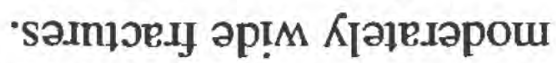

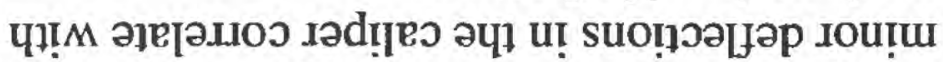

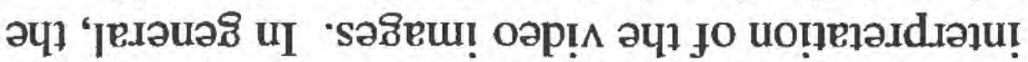

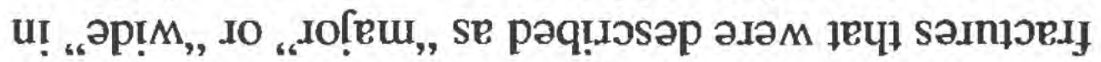

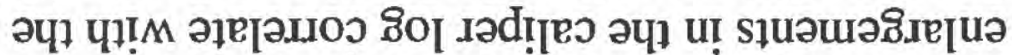

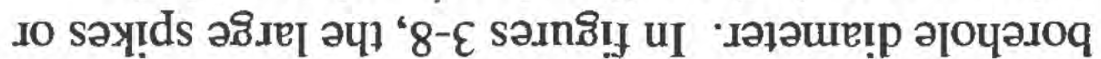

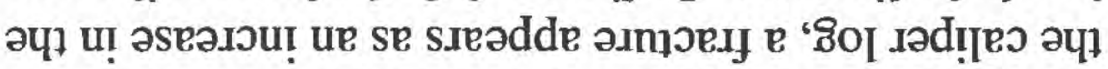

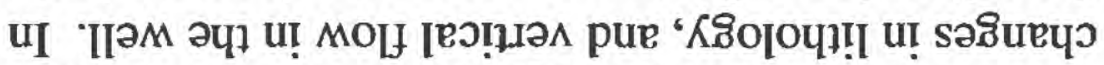

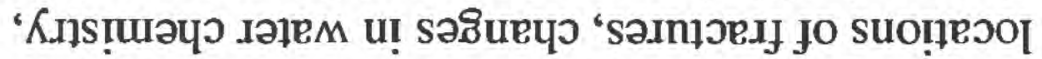

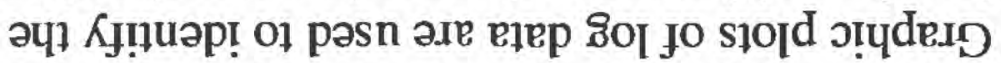

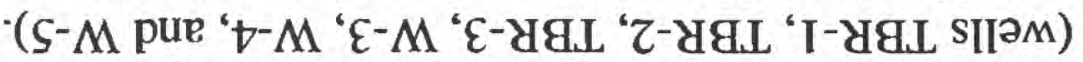

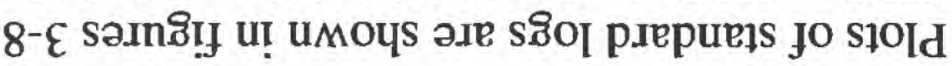

s607 pdepuets 


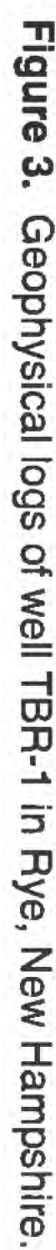
DEPTH, IN FEET BELOW TOP OF CASING

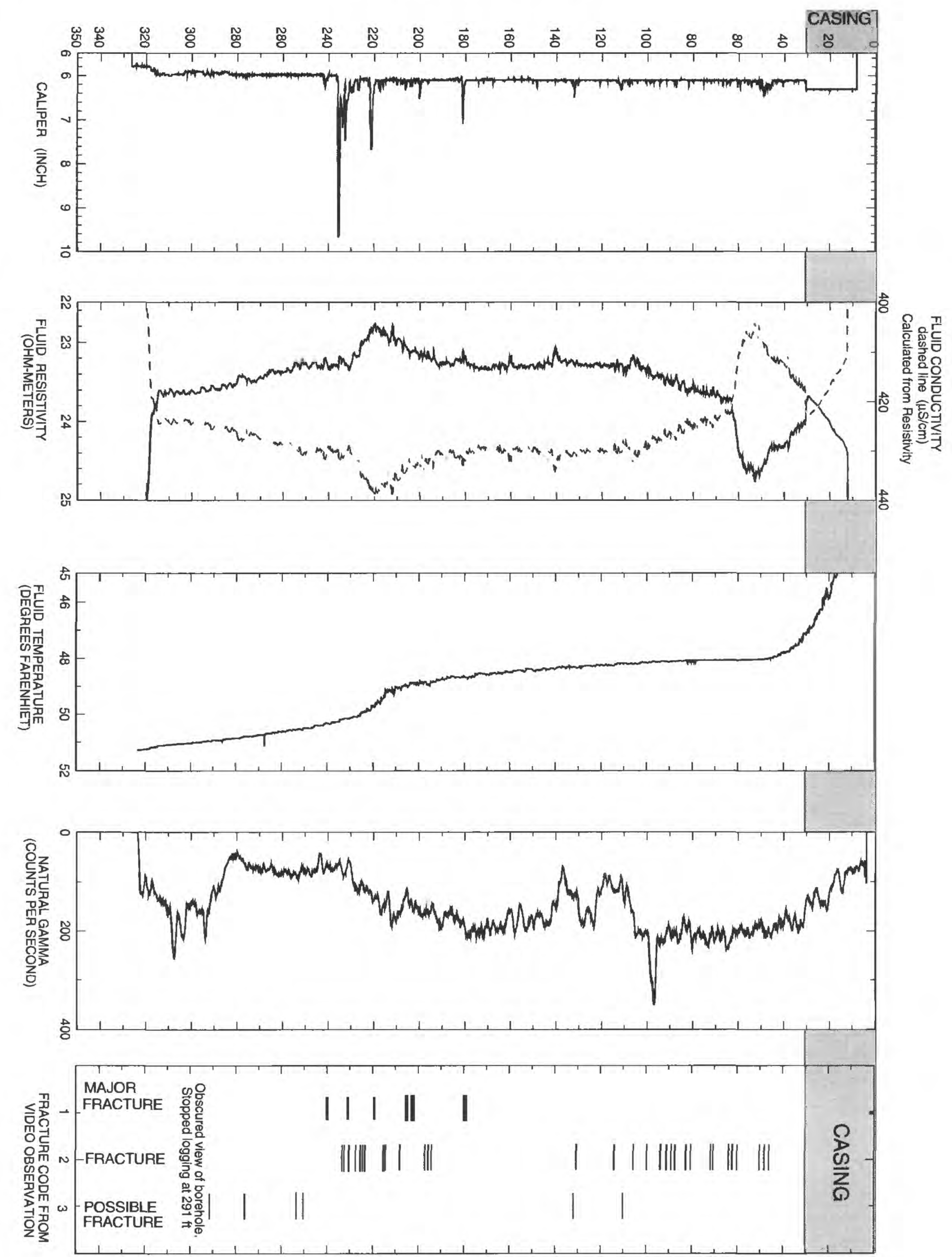

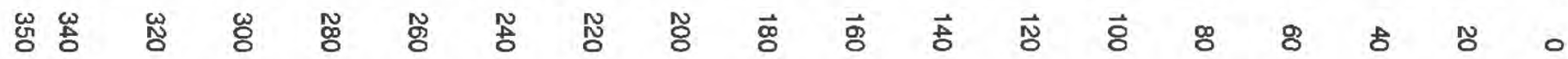
DEPTH, IN FEET BELOW TOP OF CASING 


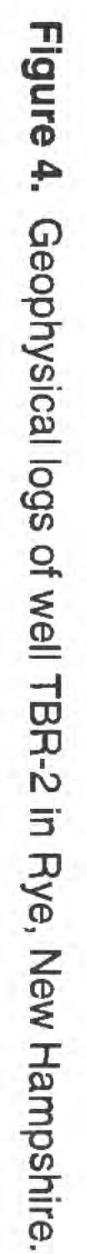
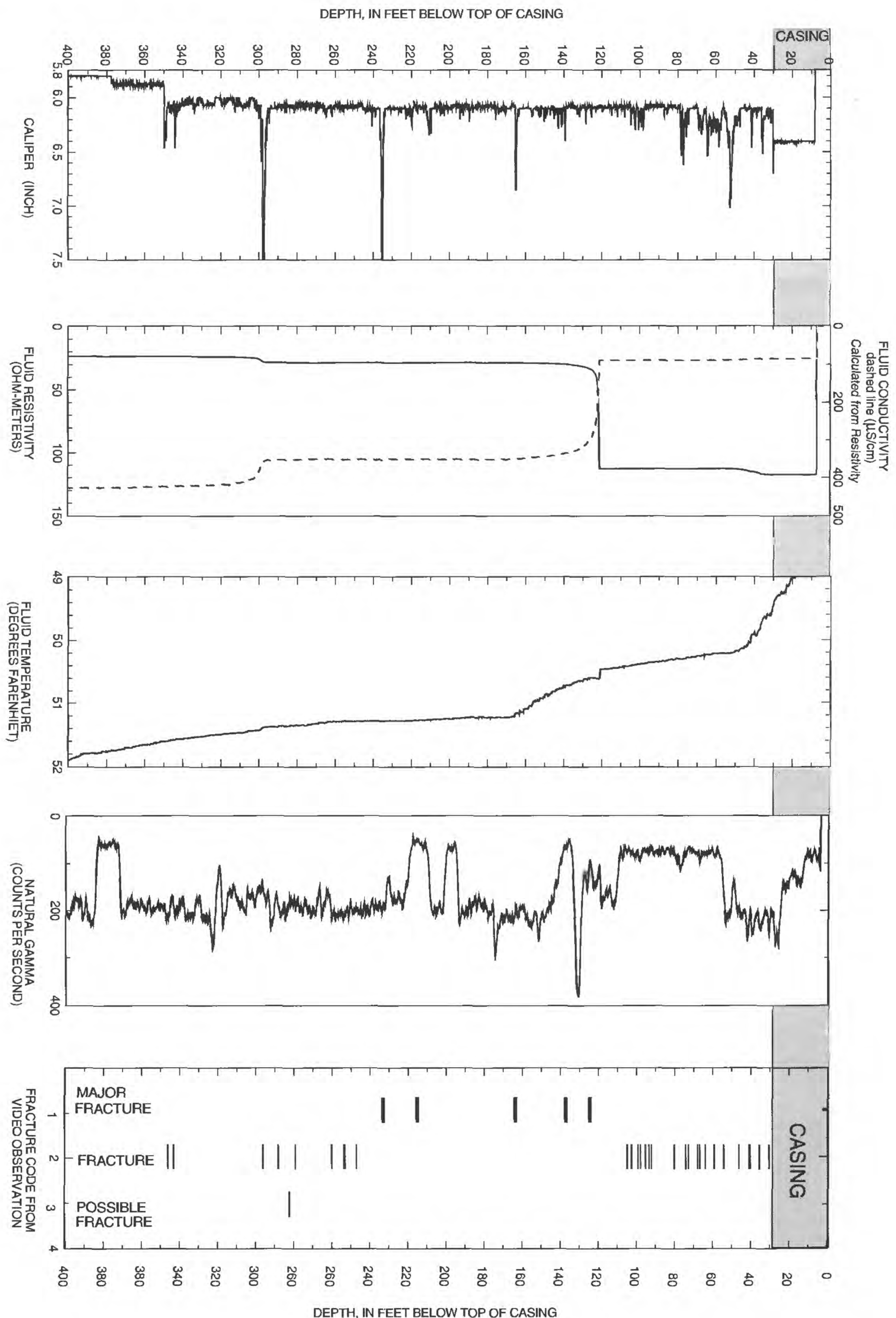

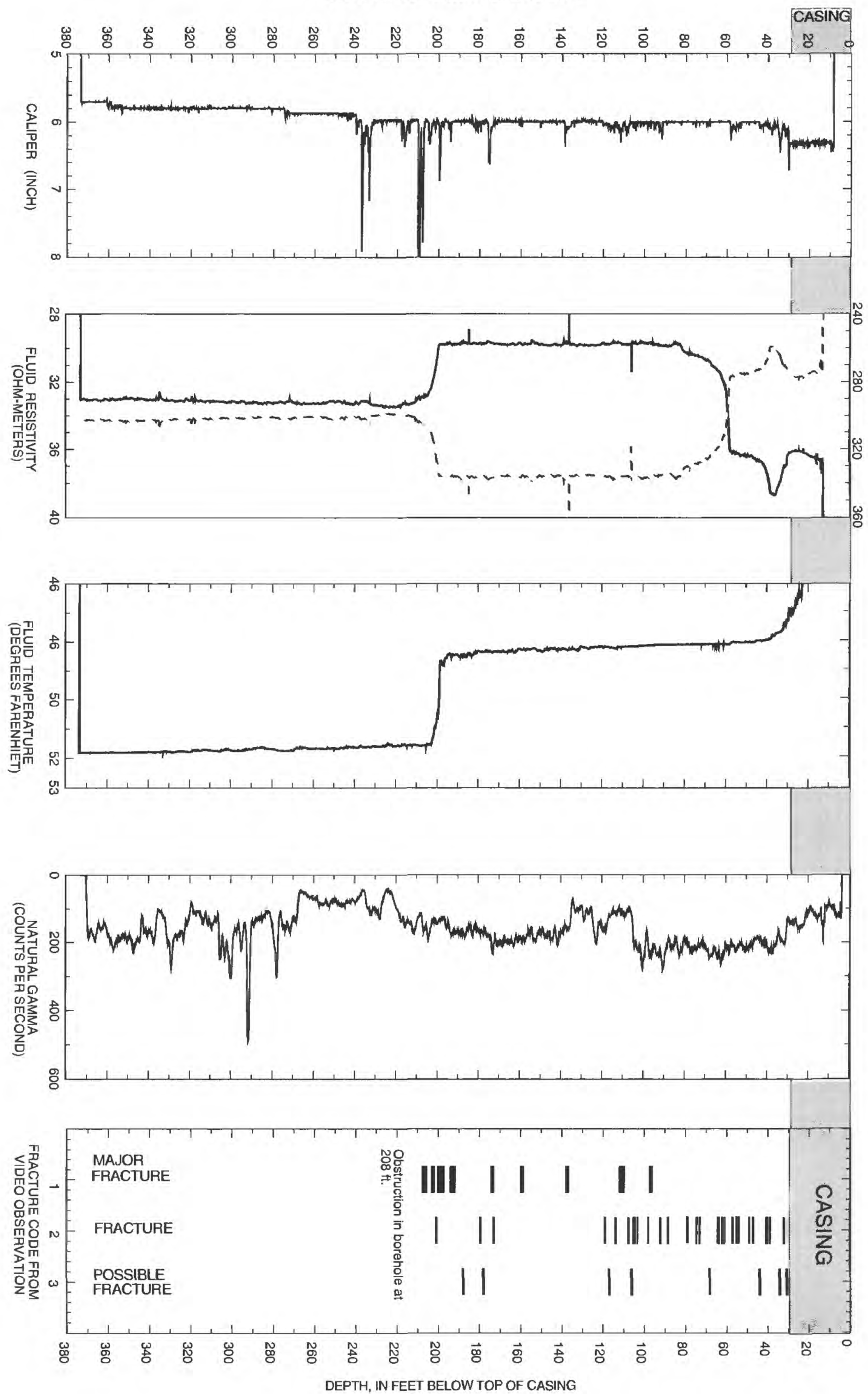


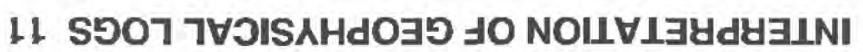

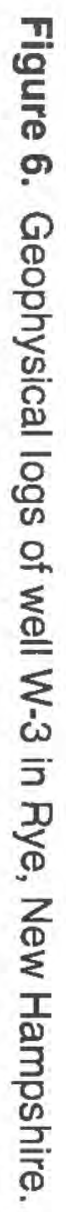

DEPTH. IN FEET BELOW TOP OF CASING
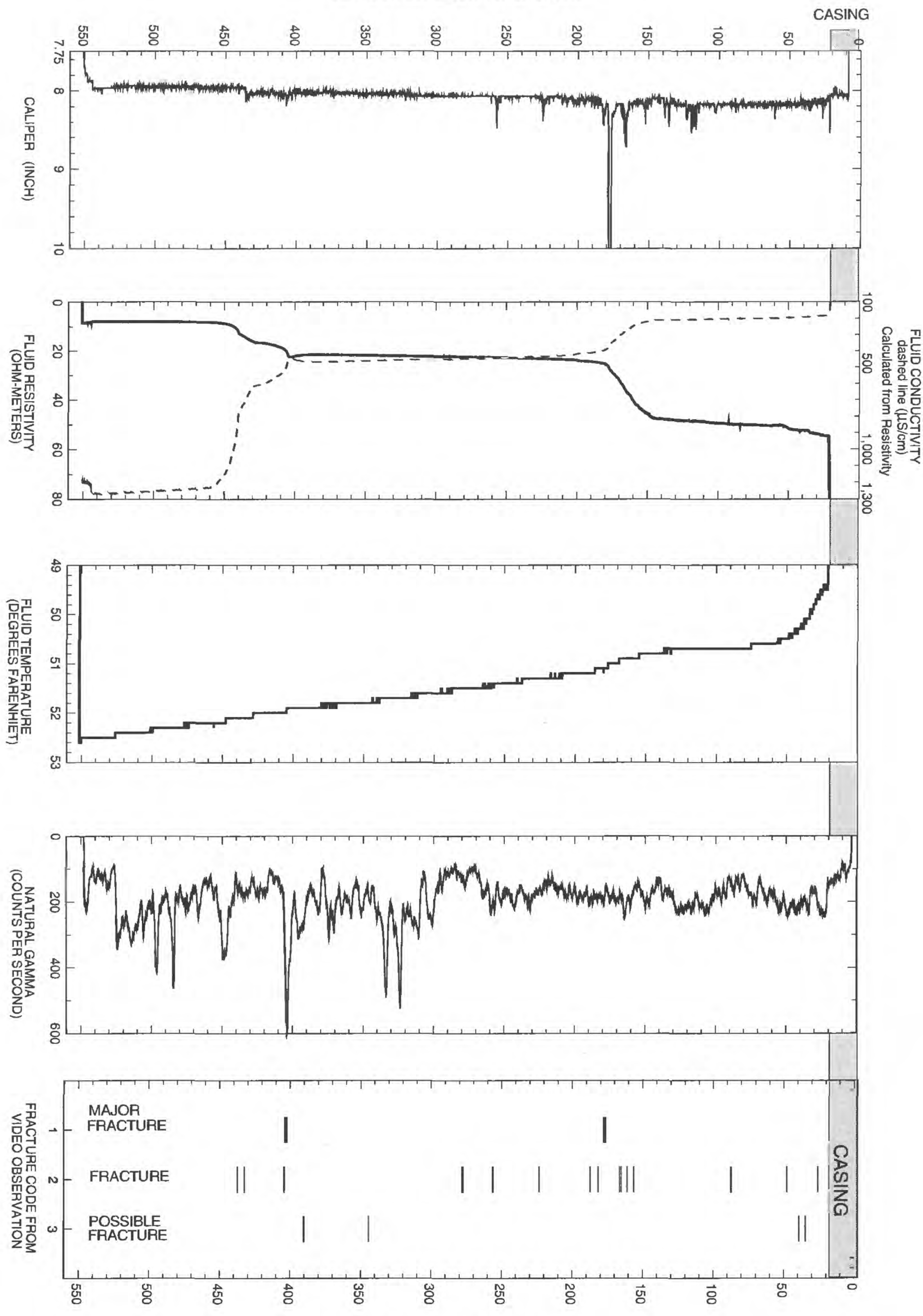

DEPTH, IN FEET BELOW TOP OF CASING 


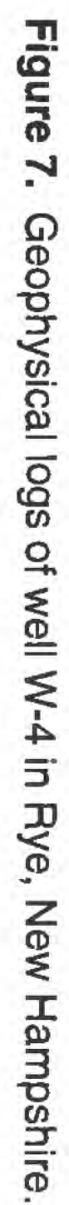

DEPTH, IN FEET BELOW TOP OF CASING
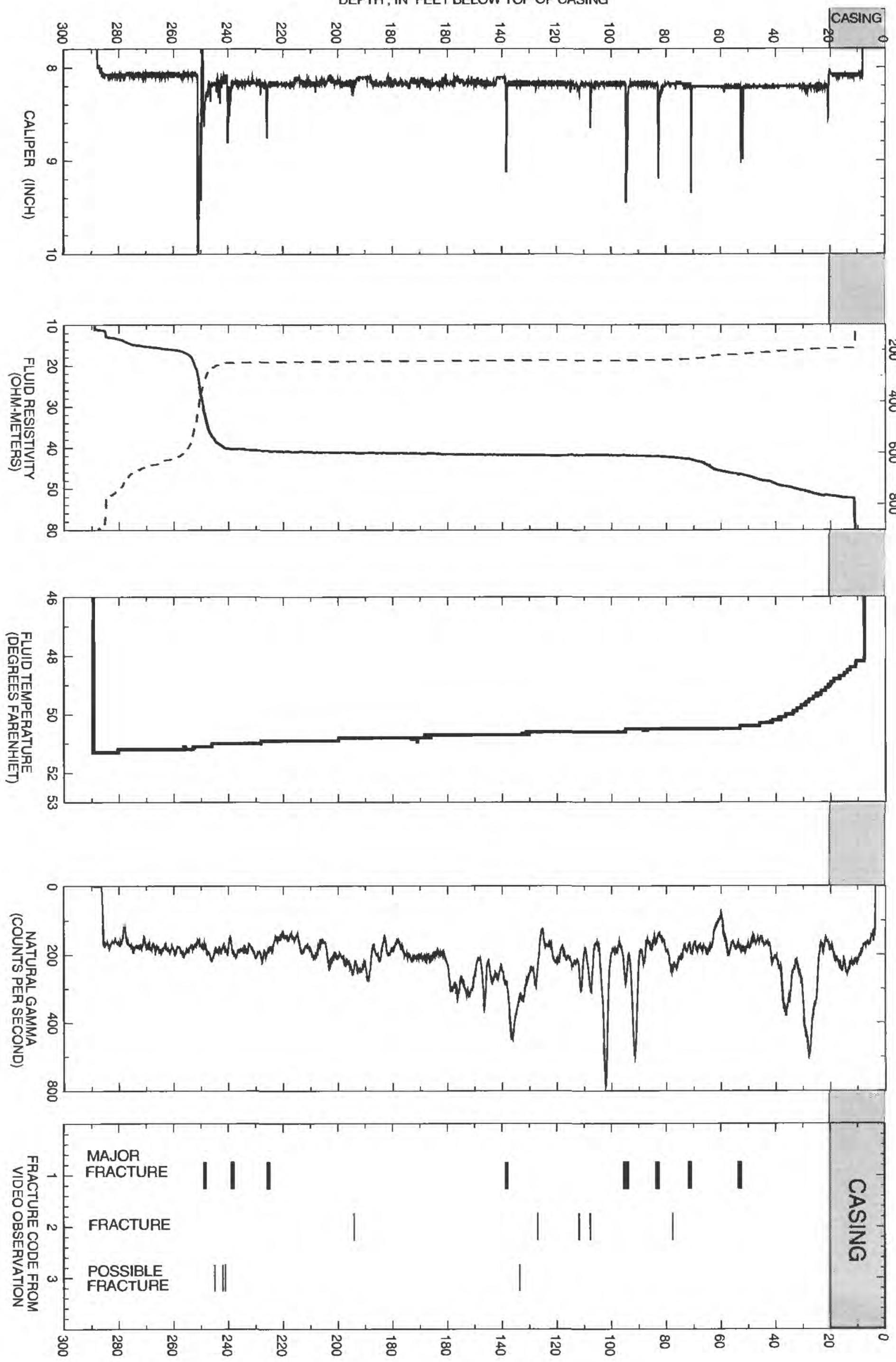

DEPTH , IN FEET BELOW TOP OF CASING 


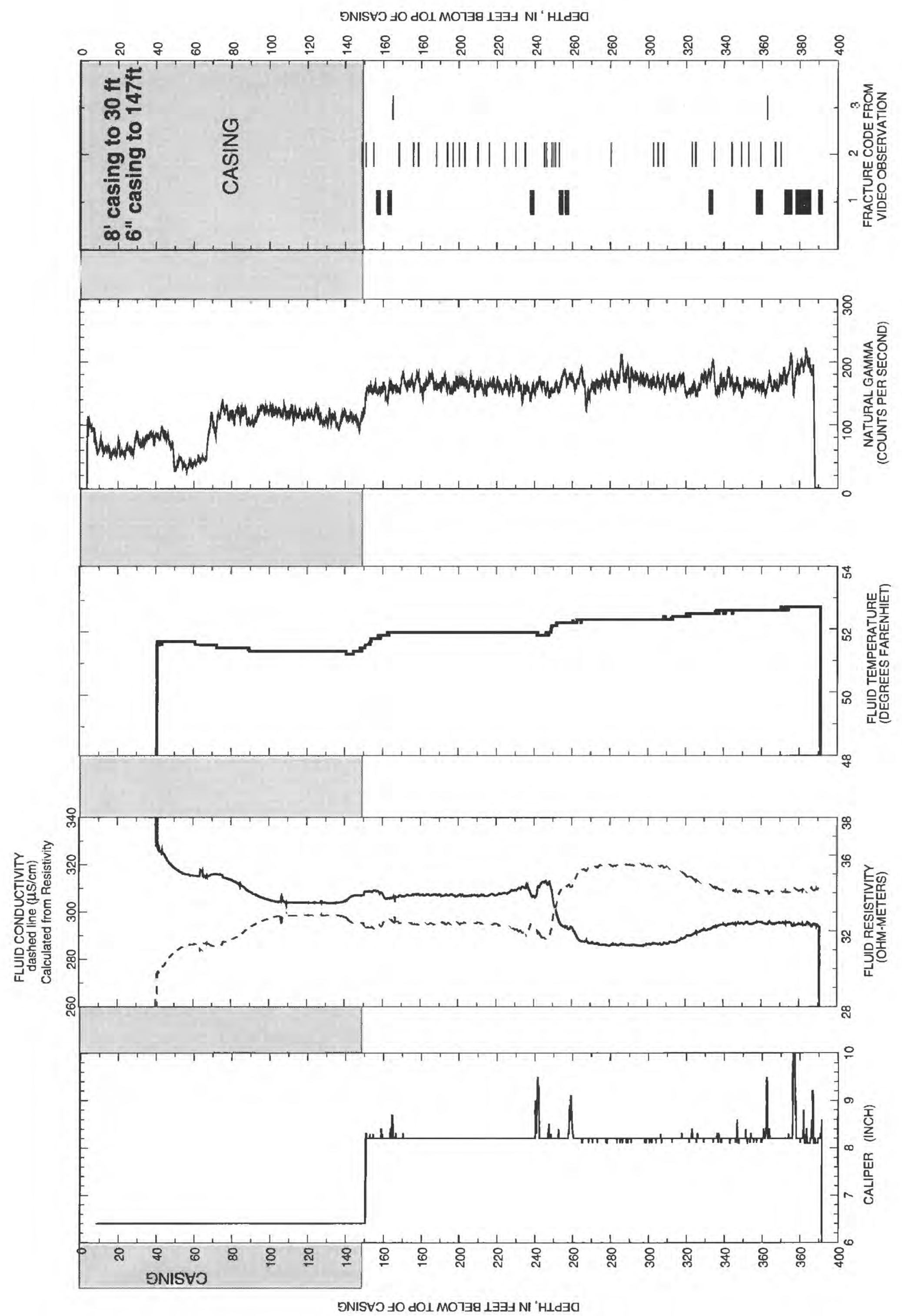

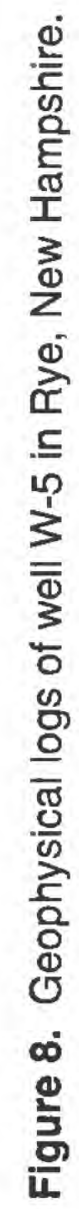


Although the caliper log in well W-4 (fig. 7) indicates numerous borehole enlargements, only three fractures affect the fluid conductivity in the borehole. These fractures, which are at 70,240 , and $250 \mathrm{ft}$, were described as major fractures in the video and ATV logs. The fluid resistivity $\log$ also shows the potential for vertical flow between the fracture at $70 \mathrm{ft}$ and the fracture zone at $240 \mathrm{ft}$.

Well W-5 (fig. 8), adjacent to the Bailey Brook municipal well, is an 8-in-diameter hole that was originally drilled to $500 \mathrm{ft}$. It collapsed and is blocked at $393 \mathrm{ft}$ in a fracture zone that appears to be open and enlarged above the blockage. In addition, a 6-in-

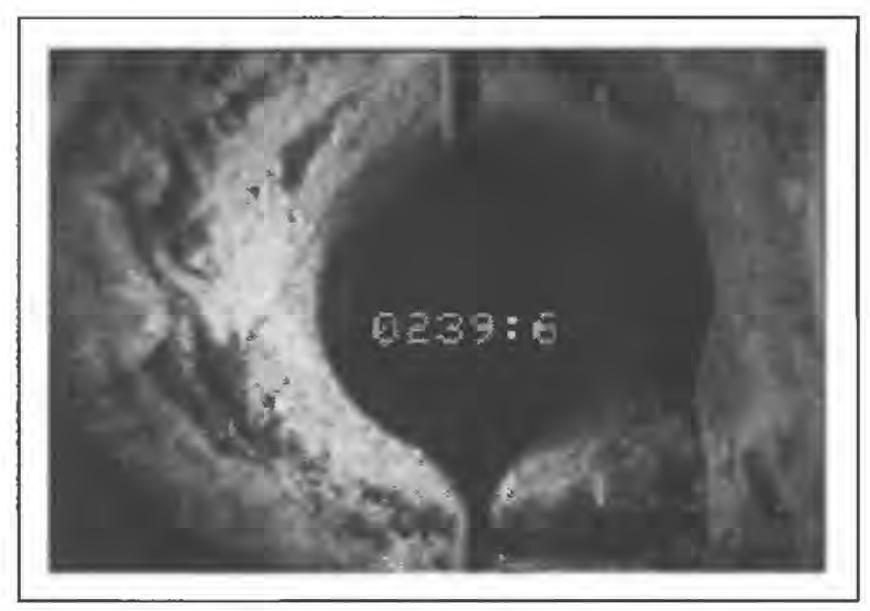

(a) Shows an open and enlarged fracture at $239.6 \mathrm{ft}$ the fracture is nearly horizontal.

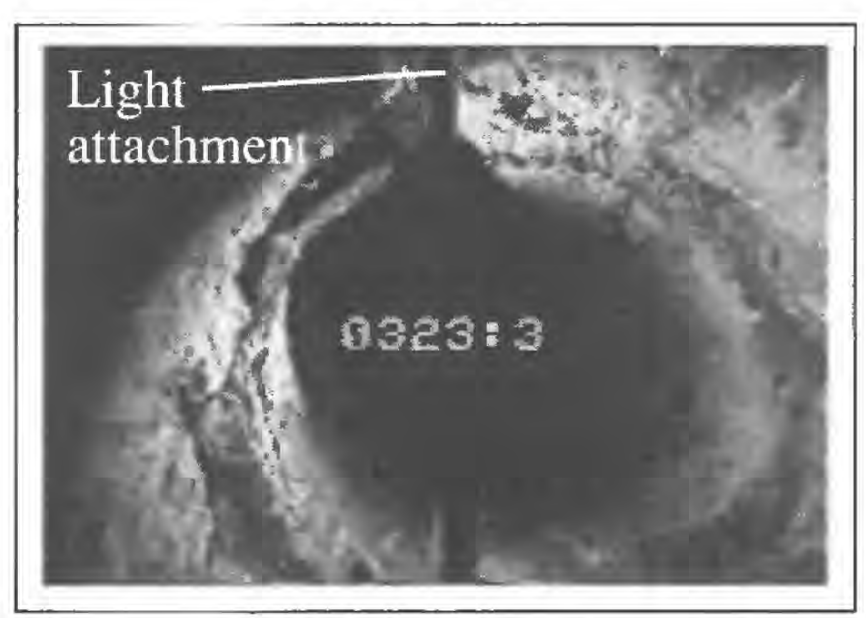

(c) Shows a nearly horizontal set of fractures that are open and oxidized. diameter casing was installed into bedrock to a depth of $139 \mathrm{ft}$, as seen in the caliper and gamma logs. The fluid conductivity $\log$ in well W-5 indicates major hydraulically active fracture zones at 240 and $260 \mathrm{ft}$ and minor zones at 160 and $320 \mathrm{ft}$. A downhole view from video images of the major fracture zones in well $\mathrm{W}-5$ at $239,256,323$, and $393 \mathrm{ft}$ are shown in figure 9. The fractures at 239 and $323 \mathrm{ft}$ (fig. 9a and 9c) appear to be nearly horizontal, whereas the fracture intersecting the well at $256 \mathrm{ft}$ (fig. 9b) is nearly vertical. Angular rocks and the enlarged borehole where the well collapsed just below an open, enlarged zone, are shown in figure $9 \mathrm{~d}$.

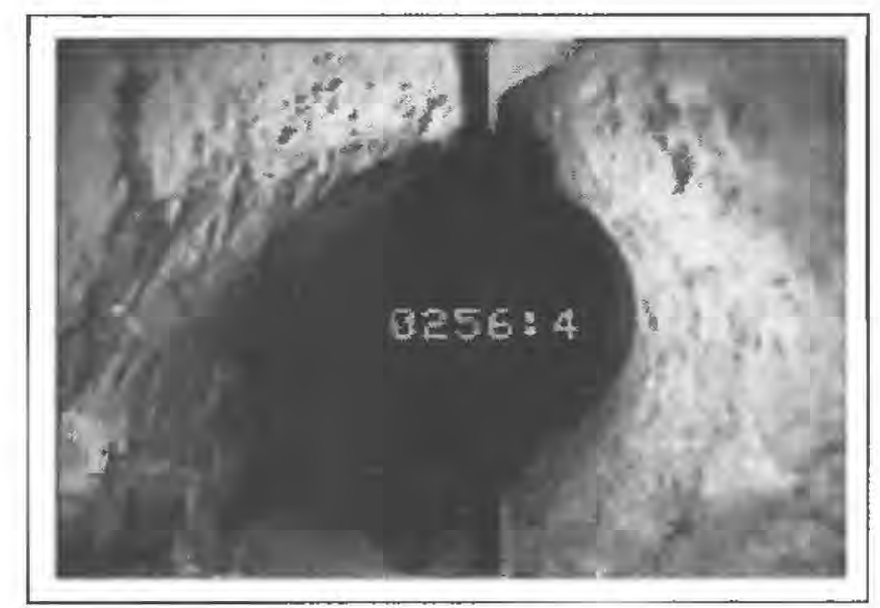

(b) Shows a vertical fracture that intersects the well at approximately $256 \mathrm{ft}$.

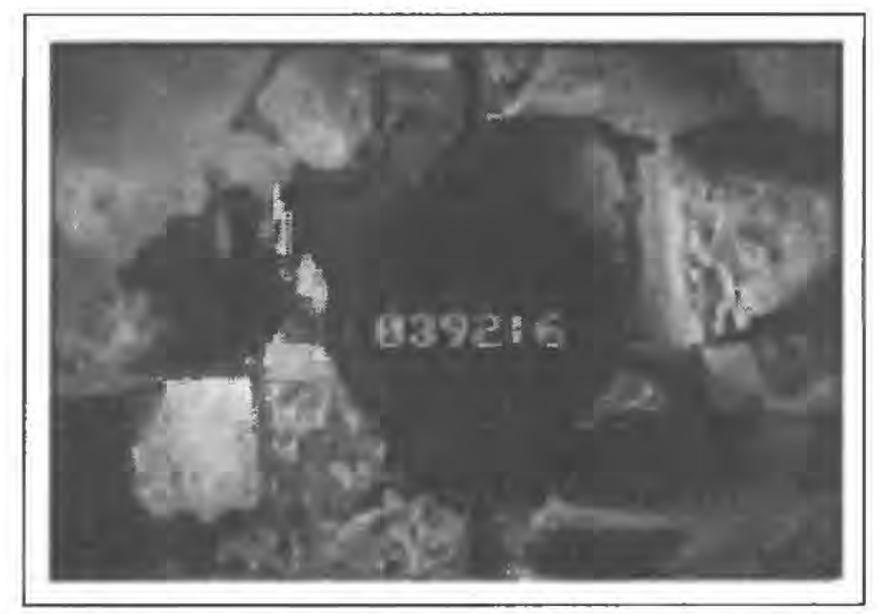

(d) Shows the zone at $393 \mathrm{ft}$ where the well collapsed at a wide, open and enlarged fracture.

Figure 9. Selected borehole video images from well W-5 in Rye, New Hampshire. The dark circle in the center of the screen is the light source to the camera, which is pointed down the well. 
Advanced Logs

The deviations of the wells are shown in radial plots (figs. $10 \mathrm{a}-\mathrm{f}$ ), in which the center of the plot for each well represents the well location at land surface. The well location is plotted as a function of depth with respect to True North. The deviation data were used in the interpretation of the ATV fracture orientations to account for the inclination of the well. Well TBR-3 deviates nearly due east $\left(\mathrm{N} 97^{\circ} \mathrm{E}\right)$. Although TBR-3 was drilled a total of $390 \mathrm{ft}$, its true depth is $366.6 \mathrm{ft}$, and the bottom of the well is $42.6 \mathrm{ft}$ east of where it originated at the land surface. Because wells in metasedimentary rocks tend to deviate into the foliation, an easterly deviating well may indicate that the foliation and fabric are dipping west. The foliation measured in the ATV log of TBR-3 had a dip direction that ranges from $\mathrm{N} 270^{\circ}$ to $\mathrm{N} 305^{\circ} \mathrm{E}$, and an average dip of $50^{\circ}$. Other nearby wells, including W-3, W-4, and TBR-2, deviate in about the same direction $\left(\mathrm{N} 100^{\circ} \mathrm{E}\right.$, $\mathrm{N} 90^{\circ} \mathrm{E}$, and $\mathrm{N} 134^{\circ} \mathrm{E}$, respectively). Well W-5, which intersects fewer foliated rocks than all the other wells, deviated only $4 \mathrm{ft}$.

Interpretations of the ATV logs and acoustic caliper logs provide the location and orientation of fractures in each well. Images of the ATV logs are provided in appendix 1 . The original digital data are stored at the USGS. The fracture planes that could be determined were assigned a code similar to the codes used in video interpretation to describe the fracture. A code of 1 indicates a feature that is unmistakably a wide aperture fracture in the ATV log. The strike and dip could not be determined at some of the enlarged fracture zones. A code of 2 indicates fractures for which there may be a descriptor listed under comments, such as "faint," or "minor" used to further describe the fracture. A code of 3 is used when the interpretation is uncertain. Sometimes it is unclear if a planar feature is related to the rock (such as foliation or igneous dikes) or if it is a fracture. The midpoint depth and strike and dip of fracture planes that could be discerned from the ATV log are listed in table 1. The strike is reported in "right-hand-rule" in azimuthal degrees east of True North. By this nomenclature, a fracture's dip is to the right of the strike direction. For example, a North-South striking fracture, with a dip to the west, would have an orientation of $N 180^{\circ} \mathrm{E}$, as opposed to $\mathrm{N} 0^{\circ} \mathrm{E}$.
A lower-hemisphere, equal-area projection, also called a stereogram, was used to plot the orientation of fractures. A stereogram reduces each fracture plane to a point that represents the intersection of a pole, perpendicular to a fracture plane, with a lower hemisphere (fig. 11). For example, a horizontal fracture would be indicated by a point in the center of the stereogram, whereas a fracture striking $\mathrm{N} 215^{\circ} \mathrm{E}$ with a dip of $80^{\circ} \mathrm{W}$ would be indicated by a point towards the right (Eastern) edge of the outer circle. The orientation of the fracture plane in figure 11 is reported as $\mathrm{N} 215^{\circ} \mathrm{E}, 80^{\circ}$, which in the right-hand-rule format implies that the fracture dips west $\left(80^{\circ}\right.$ to the right of the $215^{\circ}$ bearing).

Two stereograms were generated for each well. A series of figures that graphically depict fracture orientations from the ATV data for each of the six wells are shown in figures 12-17. Each figure includes a plot that shows the location of the fracture plotted as the fracture type (code $=1,2$ or 3 ) with respect to depth below the top of casing (fig. 12a). These plots can be compared directly with the standard logs (fig. 3-6). In addition, one stereogram, in each of the six figures, shows all of the fractures that were identified in the well (fig. 12b). In this stereogram, the symbol type indicates the type (code $=1,2$, or 3 ) of fracture. The second stereogram (fig. 12c) shows a subset of poles to fracture planes for the fractures that were interpreted as hydraulically active in the interpretation of the standard logs. The poles in these plots are labeled with the depth of intersection, which can be referenced to the standard logs and to the table (table 1) describing the ATV features. [Standard logs were collected under natural conditions, thus, under pumping conditions there could be different hydraulically active fractures.]

The poles of several of the stereograms show a wide range of orientations with no obvious pattern. The scatter in these plots is probably caused by the presence of multiple fracture sets. Because the poles to planes are not unimodal (from a single fracture population), the mean vector is not a reliable estimator of the distribution. Eigenvector analysis provides a method for evaluating the degree of clustering of poles around planes that fit through fracture sets in the distribution (Woodcock, 1977). Eigenvector analysis produces three vectors, which are fit to the distribution of poles. An eigenvalue is computed for each vector. The sum of the eigenvalues is one, and the magnitude of each eigenvalue represents the concentration of the poles associated with the respective eigenvector. 
(a) Well TBR-1

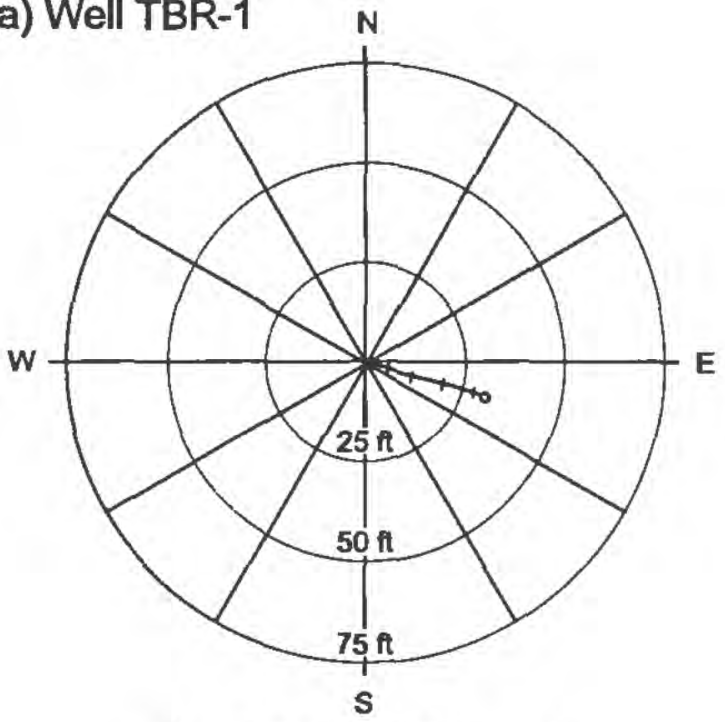

- Depth in 25-ft increments

(b) Well TBR-2 N

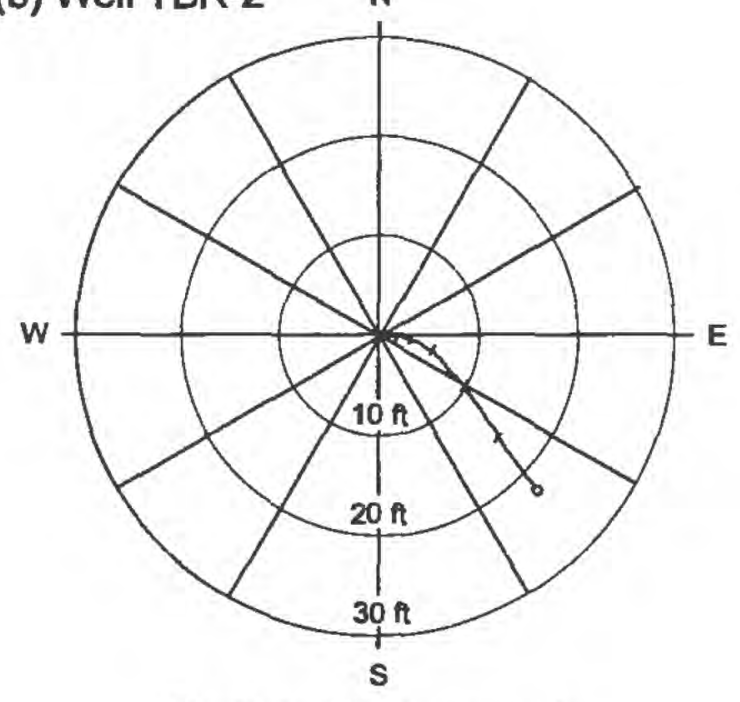

- Depth in 10-ft increments

(c) Well TBR-3

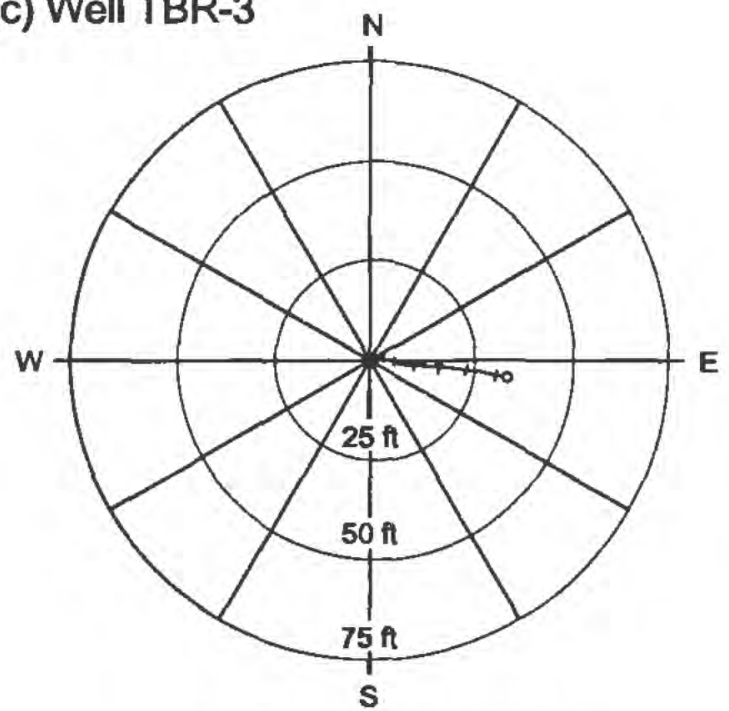

- Depth in 25-ft increments

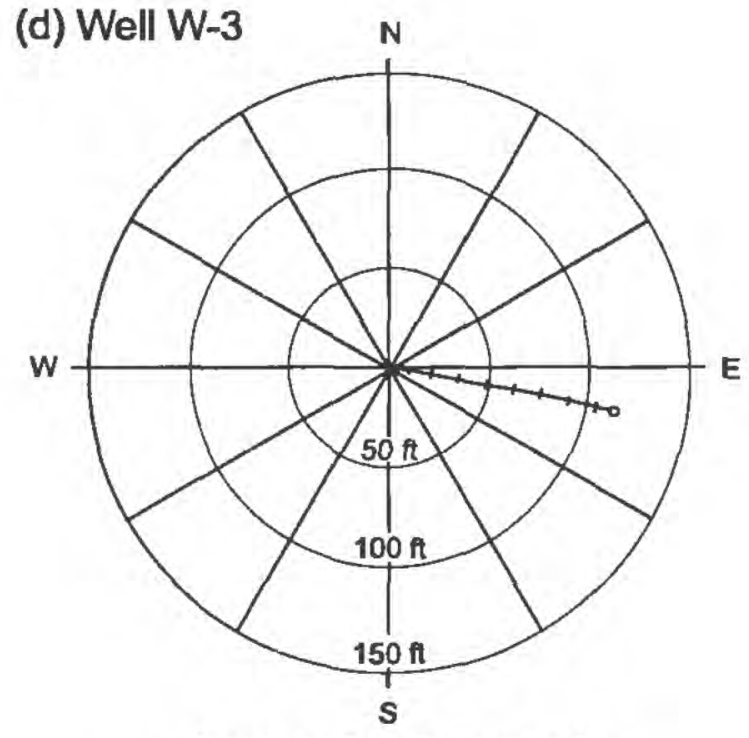

- Depth in 50-ft increments

(e) Well W-4

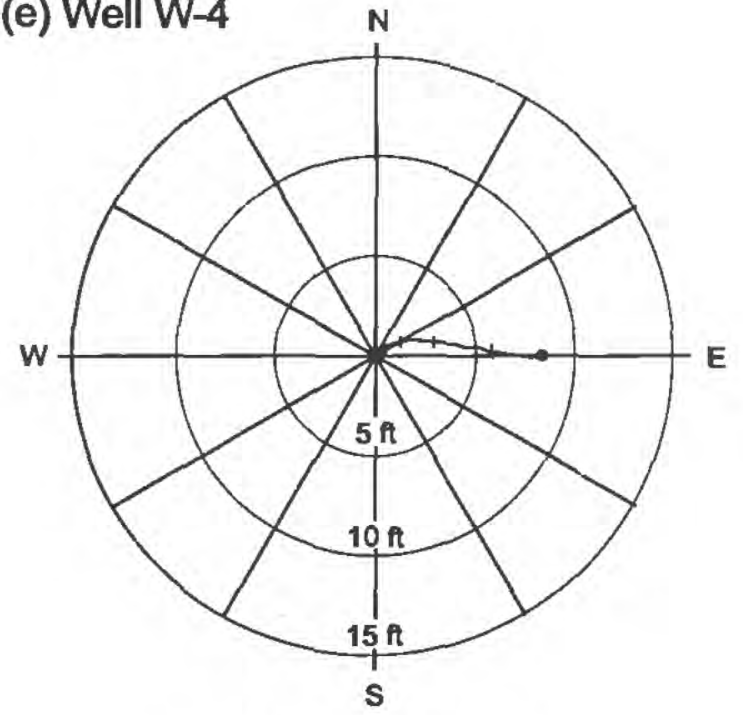

- Depth in 5-ft increments

(f) Well W-5

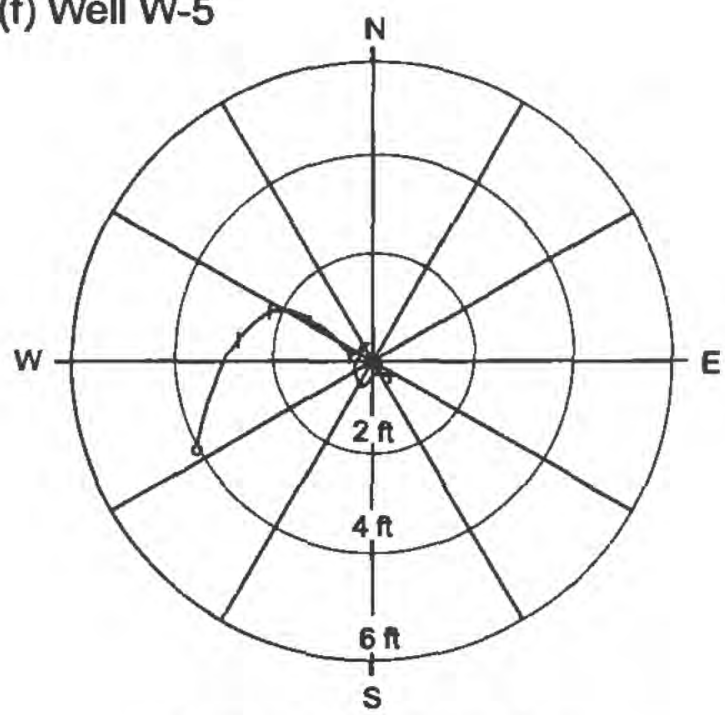

- Depth in 2-ft increments

EXPLANATION

- Bottom of hole

Figure 10. Deviation logs of wells TBR-1, TBR-2, TBR-3, W-3, W-4, and W-5 in Rye, New Hampshire. Radial distances are shown in feet (ft). 
Table 1. Midpoint depth, strike, and dip of fractures identified in wells TBR-1, TBR-2, TBR-3, W-3, W-4, and W-5, by acoustic televiewer in Rye, New Hampshire

[Strike is reported in azmuthal degrees, east of True North in "right-hand rule" where the direction of the dip is to the right of the strike; --, no data available]

\begin{tabular}{cccc}
\hline \multicolumn{3}{c}{ Well TBR-1 } \\
\hline $\begin{array}{c}\text { Mldpolnt } \\
\text { depth, } \\
\text { (in feet) }\end{array}$ & $\begin{array}{c}\text { Strlke } \\
\text { (degrees) }\end{array}$ & $\begin{array}{c}\text { Dlp } \\
\text { (degrees) }\end{array}$ & Comments \\
\hline
\end{tabular}

\begin{tabular}{|c|c|c|c|}
\hline \multicolumn{4}{|c|}{ Major fractures (code 1) } \\
\hline 49.9 & 224 & 55 & Wide fracture \\
\hline 62.8 & 330 & 5 & Wide fracture \\
\hline 63.7 & 142 & 3 & Wide fracture \\
\hline 78.7 & 188 & 29 & Wide fracture \\
\hline 82.8 & 182 & 52 & Wide fracture \\
\hline 103.0 & 325 & 58 & Fracture \\
\hline 182.1 & 154 & 48 & Top of wide fracture \\
\hline 182.5 & 152 & 47 & Bottom of wide fracture \\
\hline 197.3 & 164 & 44 & Wide fracture \\
\hline 221.0 & 54 & 30 & Top of wide fracture \\
\hline 223.6 & 154 & 14 & Bottom of wide fracture \\
\hline 228.9 & 258 & 38 & Top of big wide fracture zone \\
\hline 236.3 & 28 & 38 & Bottom of wide fracture \\
\hline 241.5 & 266 & 55 & Top of wide fracture \\
\hline 242.6 & 208 & 21 & Bottom of wide fracture \\
\hline 252.7 & 345 & 65 & Wide fracture \\
\hline \multicolumn{4}{|c|}{ Fractures (code 2) } \\
\hline 51.9 & 195 & 74 & Fracture \\
\hline 52.6 & 184 & 69 & Fracture \\
\hline 54.6 & 211 & 62 & Fracture \\
\hline 61.2 & 190 & 71 & Faint fracture \\
\hline 65.9 & 183 & 73 & Fracture \\
\hline 66.3 & 171 & 71 & Fracture \\
\hline 72.6 & 138 & 64 & Fracture \\
\hline 74.4 & 194 & 51 & Fracture \\
\hline 75.3 & 177 & 59 & Fracture \\
\hline 114.0 & 263 & 59 & $\begin{array}{l}\text { Fracture - low confidence } \\
\text { strike and dip }\end{array}$ \\
\hline 123.1 & 183 & 41 & Fracture \\
\hline 134.7 & 193 & 66 & Fracture \\
\hline 137.6 & 196 & 62 & Fracture \\
\hline 143.8 & 160 & 24 & Faint fracture \\
\hline 145.6 & 168 & 33 & Fracture \\
\hline 151.9 & 179 & 50 & Fracture \\
\hline 155.7 & 325 & 37 & Faint fracture \\
\hline 159.0 & 157 & 38 & Faint fracture \\
\hline 164.7 & 250 & 55 & Faint fracture \\
\hline 169.1 & 242 & 52 & Fracture \\
\hline 197.7 & 165 & 27 & Fracture \\
\hline 199.8 & 353 & 58 & Fracture \\
\hline 201.4 & 47 & 68 & Fracture \\
\hline 203.1 & 175 & 28 & Fracture \\
\hline 204.4 & 10 . & 57 & Fracture \\
\hline 205.0 & 12 & 75 & Fracture \\
\hline
\end{tabular}

\begin{tabular}{cccc}
\hline & \multicolumn{2}{c}{ Well TBR-1-Contlnued } \\
\hline $\begin{array}{c}\text { Midpoint } \\
\text { depth, } \\
\text { (in feet) }\end{array}$ & $\begin{array}{c}\text { Strike } \\
\text { (degrees) }\end{array}$ & $\begin{array}{c}\text { Dip } \\
\text { (degrees) }\end{array}$ & Comments \\
\hline
\end{tabular}

\begin{tabular}{rrrl}
\hline & \multicolumn{3}{c}{ Fractures (code 2)-Continued } \\
209.6 & 146 & 31 & Fracture \\
210.6 & 6 & 49 & Fracture \\
211.3 & 15 & 56 & Fracture \\
216.1 & 154 & 35 & Fracture \\
217.1 & 11 & 33 & Fracture \\
217.4 & 191 & 77 & Fracture \\
219.2 & 195 & 80 & Fracture \\
246.8 & 322 & 70 & Faint fracture- \\
248.1 & 158 & 7 & Fracture \\
277.9 & 133 & 74 & Fracture \\
278.7 & 131 & 79 & Fracture \\
& & Possible fractures (code 3) \\
67.9 & 206 & 79 & Possible fracture \\
86.8 & 158 & 63 & Possible fracture \\
97.3 & 203 & 41 & Possible fracture \\
101.3 & 277 & 45 & Possible fracture \\
110.6 & 228 & 66 & Possible fracture \\
181.4 & 338 & 5 & Possible fracture \\
207.4 & 35 & 77 & Bottom of a partial fracture \\
240.5 & 342 & 49 & Possible fracture \\
255.3 & 353 & 51 & Possible fracture \\
326.6 & & & Bottom of well \\
& & & \\
\hline
\end{tabular}

\begin{tabular}{cccc}
\hline & \multicolumn{3}{c}{ Well TBR-2 } \\
\hline $\begin{array}{c}\text { Midpoint } \\
\text { depth, } \\
\text { (in feet) }\end{array}$ & $\begin{array}{c}\text { Strike } \\
\text { (degrees) }\end{array}$ & $\begin{array}{c}\text { Dlp } \\
\text { (degrees) }\end{array}$ & Comments \\
\hline
\end{tabular}

\begin{tabular}{rrrl} 
& \multicolumn{3}{c}{ Major fractures (code 1) } \\
39.7 & 107 & 10 & Top of wide fracture \\
40.4 & 126 & 16 & Bottom of wide fracture \\
45.2 & 108 & 4 & Top of wide fracture \\
45.7 & 91 & 18 & Bottom of wide fracture \\
80.4 & 134 & 32 & Fracture \\
81.9 & 207 & 73 & Bottom of wide fracture \\
128.6 & 165 & 23 & Wide fracture \\
142.8 & 243 & 74 & Wide fracture \\
167.6 & 358 & 24 & Wide fracture \\
212.0 & 32 & 69 & Wide fracture \\
236.6 & 230 & 49 & Bottom of wide fracture zone \\
237.5 & 239 & 61 & Bottom of wide fracture zone \\
297.8 & 203 & 58 & Top of wide fracture \\
298.6 & 193 & 47 & Bottom of wide fracture \\
349.3 & 213 & 58 & Top of wide fracture \\
350.0 & 213 & 62 & Bottom of wide fracture
\end{tabular}


Table 1. Midpoint depth, strike, and dip of fractures identified in wells TBR-1, TBR-2, TBR-3, W-3, W-4, and W-5, by acoustic televiewer in Rye, New Hampshire--Continued

\begin{tabular}{|c|c|c|c|c|c|c|c|}
\hline \multicolumn{4}{|c|}{ Well TBR-2-ContInued } & \multicolumn{4}{|c|}{ Well TBR-2-ContInued } \\
\hline $\begin{array}{l}\text { Midpoint } \\
\text { depth, } \\
\text { (In feet) }\end{array}$ & $\begin{array}{c}\text { Strike } \\
\text { (degrees) }\end{array}$ & $\begin{array}{c}\text { Dip } \\
\text { (degrees) }\end{array}$ & Comments & $\begin{array}{l}\text { Mldpoint } \\
\text { depth, } \\
\text { (In feet) }\end{array}$ & $\begin{array}{c}\text { Strike } \\
\text { (degrees) }\end{array}$ & $\begin{array}{c}\text { Dip } \\
\text { (degrees) }\end{array}$ & Comments \\
\hline \multicolumn{4}{|c|}{ Fractures (code 2) } & \multicolumn{4}{|c|}{ Fractures (code 2)--Continued } \\
\hline 51.6 & 248 & 16 & Fracture & 335.0 & 196 & 58 & Fracture \\
\hline 55.4 & 242 & 67 & Fracture & 336.5 & 215 & 54 & Faint fracture \\
\hline 59.6 & 342 & 21 & Fracture & 344.6 & 198 & 40 & Fracture wide \\
\hline 61.7 & 260 & 83 & Fracture with irregular shape & 347.5 & 193 & 32 & Fracture \\
\hline 68.3 & 276 & 63 & Fracture & \multicolumn{4}{|c|}{ Possible fractures (code 3) } \\
\hline 68.3 & 287 & 69 & Fracture & 57.2 & 236 & 75 & Possible fracture \\
\hline 72.7 & 235 & 73 & Fracture & 68.7 & 266 & 78 & Possible fracture \\
\hline 78.4 & 24 & 75 & Fracture & 101.3 & 353 & 64 & Fracture or contact \\
\hline 83.3 & 97 & 10 & Fracture & 113.5 & 258 & 80 & Fracture or contact \\
\hline 84.6 & 251 & 31 & Faint fracture & 122.5 & 113 & 43 & Fracture or lithologic contact \\
\hline 84.7 & 241 & 32 & Faint fracture & 196.7 & 62 & 53 & Possible fracture \\
\hline 86.3 & 356 & 7 & Faint fracture & 266.2 & 83 & 69 & Possible fracture \\
\hline 87.2 & 218 & 73 & Faint fracture & 267.3 & 277 & 17 & Possible fracture \\
\hline 89.7 & 226 & 70 & Fracture & 282.3 & 168 & 63 & Possible fracture \\
\hline 92.3 & 354 & 11 & Fracture & 296.7 & 184 & 51 & Possible fracture \\
\hline 94.7 & 33 & 17 & Fracture & 299.7 & 323 & 17 & Possible fracture \\
\hline 95.8 & 21 & 14 & Faint fracture & 302.0 & 313 & 19 & Fracture or lithologic contact \\
\hline 97.3 & 345 & 7 & Fracture & 313.5 & 223 & 61 & Possible fracture \\
\hline 98.1 & 3 & 7 & Faint fracture & 329.5 & 199 & 58 & Possible fracture \\
\hline 98.2 & 20 & 5 & Faint fracture & 402.0 & -- & -- & Major fracture \\
\hline $\begin{array}{l}100.0 \\
103.8\end{array}$ & $\begin{array}{r}105 \\
90\end{array}$ & $\begin{array}{l}55 \\
27\end{array}$ & $\begin{array}{l}\text { Fracture } \\
\text { Fracture }\end{array}$ & \multicolumn{4}{|c|}{ Well TBR-3 } \\
\hline 106.3 & 230 & 79 & Fracture with irregular shape & \multirow{2}{*}{$\begin{array}{l}\text { Midpoint } \\
\text { depth, } \\
\text { (in feet) }\end{array}$} & \multirow{2}{*}{$\begin{array}{c}\text { Strike } \\
\text { (degrees) }\end{array}$} & \multirow{2}{*}{$\begin{array}{c}\text { Dip } \\
\text { (degrees) }\end{array}$} & \multirow[b]{2}{*}{ Comments } \\
\hline 106.7 & 194 & 80 & Fracture with irregular shape & & & & \\
\hline 106.9 & 88 & 26 & Fracture & \multicolumn{4}{|c|}{ Major fractures (code 1) } \\
\hline 109.5 & 356 & 17 & Fracture & 43.9 & 169 & 30 & Wide fracture \\
\hline 110.3 & 210 & 71 & Fracture with irregular shape & 47.1 & 190 & 19 & Wide fracture \\
\hline 111.0 & 316 & 43 & Fracture & 61.0 & 184 & 37 & Top of wide fracture \\
\hline 112.0 & 89 & 45 & Fracture & 61.2 & 192 & 33 & Bottom of wide fracture \\
\hline 113.1 & 329 & 30 & Fracture & 140.7 & 269 & 26 & Top of wide fracture \\
\hline 116.4 & 251 & 56 & $\begin{array}{l}\text { Fracture } \\
\text { Eaint fracture }\end{array}$ & 141.0 & 268 & 22 & Bottom of wide fracture \\
\hline 120.6 & 138 & 44 & $\begin{array}{l}\text { Faint fracture } \\
\text { Fracture }\end{array}$ & 161.7 & 189 & 28 & Wide fracture \\
\hline 123.2 & 109 & 50 & $\begin{array}{l}\text { Fracture } \\
\text { Fracture }\end{array}$ & 162.5 & 252 & 51 & Wide fracture \\
\hline 128.3 & $\begin{array}{r}80 \\
340\end{array}$ & $\begin{array}{r}24 \\
8\end{array}$ & $\begin{array}{l}\text { Fracture } \\
\text { Fracture }\end{array}$ & 177.0 & 145 & 40 & Top of wide fracture \\
\hline $\begin{array}{l}167.1 \\
211.6\end{array}$ & $\begin{array}{r}349 \\
15\end{array}$ & $\begin{array}{r}0 \\
58\end{array}$ & Fracture & 177.9 & 175 & 29 & Bottom of wide fracture \\
\hline 218.6 & 263 & 54 & Fracture & 182.9 & 152 & 31 & Wide fracture \\
\hline 218.8 & 248 & 40 & Fracture & 191.0 & 158 & 38 & Wide fracture \\
\hline 221.8 & 25 & 64 & Fracture & 195.6 & 81 & 6 & Top of wide fracture \\
\hline 254.3 & 168 & 54 & Fracture & 196.9 & 156 & 29 & Bottom of wide fracture \\
\hline 257.1 & 146 & 35 & Fracture & 200.7 & 12 & 33 & Top of wide fracture \\
\hline 262.3 & 130 & 63 & Fracture & 203.0 & 18 & 54 & Wide fracture \\
\hline 271.3 & 331 & 27 & Fracture & 205.5 & 183 & 36 & Wide fracture \\
\hline 308.7 & 201 & 73 & Fracture & 205.9 & 21 & 68 & Wide fracture \\
\hline & & & & 209.1 & 42 & 36 & Top of wide fracture \\
\hline
\end{tabular}


Table 1. Midpoint depth, strike, and dip of fractures identified in wells TBR-1, TBR-2, TBR-3, W-3, W-4, and W-5, by acoustic televiewer in Rye, New Hampshire--Continued

\begin{tabular}{|c|c|c|c|c|c|c|c|}
\hline \multicolumn{4}{|c|}{ Well TBR-3-Continued } & \multicolumn{4}{|c|}{ Well TBR-3-Continued } \\
\hline $\begin{array}{l}\text { Midpoint } \\
\text { depth, } \\
\text { (in feet) }\end{array}$ & $\begin{array}{c}\text { Strike } \\
\text { (degrees) }\end{array}$ & $\begin{array}{c}\text { Dip } \\
\text { (degrees) }\end{array}$ & Comments & $\begin{array}{l}\text { Midpoint } \\
\text { depth, } \\
\text { (in feet) }\end{array}$ & $\begin{array}{c}\text { Strike } \\
\text { (degrees) }\end{array}$ & $\begin{array}{c}\text { Dip } \\
\text { (degrees) }\end{array}$ & Comments \\
\hline \multicolumn{4}{|c|}{ Major fractures (code 1)--Continued } & \multicolumn{4}{|c|}{ Fractures (code 2)--Continued } \\
\hline 209.9 & 352 & 28 & Bottom of wide fracture & 220.5 & 110 & 70 & Faint fracture \\
\hline 210.4 & 69 & 33 & Top of wide fracture & 222.1 & 202 & 68 & Faint fracture \\
\hline 211.4 & 153 & 38 & Bottom of wide fracture & 224.5 & 289 & 59 & Fracture \\
\hline 217.3 & 154 & 27 & Top of wide fracture & 228.8 & 118 & 80 & Fracture \\
\hline 218.2 & 149 & 16 & Bottom of wide fracture & 237.0 & 335 & 59 & Fracture \\
\hline 219.3 & 170 & 34 & Top of wide fracture & 240.7 & 44 & 78 & Faint fracture \\
\hline 219.6 & 185 & 31 & Bottom of wide fracture & 246.4 & 29 & 52 & Fracture \\
\hline 228.9 & 273 & 39 & Wide fracture & 246.7 & 234 & 81 & Fracture \\
\hline 234.0 & 263 & 41 & Top of wide fracture & 246.7 & 350 & 61 & Fracture \\
\hline 235.6 & 268 & 34 & Bottom of wide fracture & 248.8 & 232 & 77 & Fracture \\
\hline 237.8 & 126 & 28 & Top of wide fracture & 249.0 & 311 & 72 & Fracture \\
\hline 238.7 & 121 & 25 & Bottom of wide fracture & 249.7 & 319 & 77 & Faint fracture \\
\hline 240.3 & 153 & 6 & Top of wide fracture & 251.9 & 19 & 53 & Fracture \\
\hline 241.0 & 99 & 21 & Bottom of wide fracture & 256.6 & 15 & 45 & Faint fracture \\
\hline \multicolumn{4}{|c|}{ Fractures (code 2) } & 259.6 & 104 & 56 & Faint fracture \\
\hline 43.2 & 113 & 64 & Fracture & 263.6 & 120 & 72 & Fracture \\
\hline 50.3 & 276 & 70 & Fracture & 265.5 & 124 & 58 & Fracture \\
\hline 52.1 & 281 & 58 & Fracture & 276.1 & 111 & 82 & Fracture \\
\hline 59.4 & 211 & 65 & Fracture & 286.4 & 189 & 34 & Fracture \\
\hline 62.9 & 279 & 78 & Faint fracture & 288.7 & 278 & 76 & Fracture \\
\hline 71.5 & 286 & 57 & Fracture & 290.2 & 182 & 28 & Fracture \\
\hline 78.0 & 201 & 31 & Fracture & 292.8 & 205 & 25 & Fracture \\
\hline 87.8 & 163 & 82 & Faint fracture & 294.8 & 95 & 85 & Faint fracture \\
\hline 95.4 & 229 & 36 & Fracture & 310.5 & 237 & 37 & Fracture \\
\hline 100.4 & 294 & 72 & Fracture & 310.9 & 243 & 69 & Faint fracture \\
\hline 104.1 & 185 & 52 & Fracture & 316.8 & 225 & 25 & Fracture \\
\hline 104.4 & 148 & 60 & Fracture & 350.4 & 256 & 33 & Fracture \\
\hline 106.9 & 280 & 39 & Fracture & 351.2 & 278 & 68 & Fracture \\
\hline 108.2 & 88 & 41 & Fracture & 353.7 & 211 & 41 & Fracture \\
\hline 109.6 & 142 & 22 & Fracture & 358.8 & 156 & 71 & Fracture \\
\hline 113.8 & 296 & 60 & Fracture & 360.1 & 143 & 80 & Fracture \\
\hline 114.3 & 214 & 63 & Fracture & 362.2 & 265 & 63 & Faint fracture \\
\hline 120.9 & 51 & 82 & Faint fracture & \multicolumn{4}{|c|}{ Possible fractures (code 3) } \\
\hline 121.1 & 212 & 47 & Fracture & 59.9 & 305 & 64 & Possible fracture \\
\hline 122.3 & 177 & 32 & Fracture & 70.8 & 217 & 59 & Possible fracture \\
\hline 140.6 & 167 & 34 & Fracture & 76.2 & 152 & 15 & Possible fracture \\
\hline 142.7 & 167 & 52 & Fracture & 86.4 & 185 & 59 & Possible fracture \\
\hline 179.9 & 211 & 72 & Faint fracture & 103.7 & 210 & 60 & Possible fracture \\
\hline 180.6 & 153 & 30 & Fracture & 117.2 & 191 & 52 & Fracture or contact \\
\hline 192.7 & 190 & 36 & Fracture & 117.5 & 187 & 50 & Fracture or contact \\
\hline 198.3 & 129 & 79 & Fracture & 118.3 & 160 & 18 & Fracture or contact \\
\hline 201.5 & 173 & 68 & Fracture & 130.6 & 175 & 21 & Fracture or contact \\
\hline 201.7 & 105 & 25 & Fracture & 142.8 & 303 & 73 & Possible fracture \\
\hline 216.5 & 190 & 72 & Fracture & 152.9 & 212 & 50 & Possible fracture \\
\hline
\end{tabular}


Table 1. Midpoint depth, strike, and dip of fractures identified in wells TBR-1, TBR-2, TBR-3, W-3, W-4, and W-5, by acoustic televiewer in Rye, New Hampshire--Continued

\begin{tabular}{|c|c|c|c|}
\hline \multicolumn{4}{|c|}{ Well TBR-3-Continued } \\
\hline $\begin{array}{l}\text { Midpoint } \\
\text { depth, } \\
\text { (in feet) }\end{array}$ & $\begin{array}{c}\text { Strike } \\
\text { (degrees) }\end{array}$ & $\begin{array}{c}\text { Dip } \\
\text { (degrees) }\end{array}$ & Comments \\
\hline \multicolumn{4}{|c|}{ Possible fractures (code 3)--Continued } \\
\hline 157.8 & 170 & 35 & Fracture or contact \\
\hline 180.0 & 72 & 13 & Possible fracture \\
\hline 181.3 & 5 & 17 & Possible fracture \\
\hline 183.4 & 168 & 30 & Possible fracture \\
\hline 183.9 & 151 & 26 & Possible fracture \\
\hline 184.2 & 140 & 21 & Possible fracture \\
\hline 185.1 & 160 & 24 & Possible fracture \\
\hline 230.8 & 252 & 38 & Fracture or contact \\
\hline 259.8 & 66 & 34 & Possible fracture \\
\hline 270.8 & 275 & 77 & Possible fracture \\
\hline 284.8 & 274 & 74 & Possible fracture \\
\hline 311.4 & 188 & 36 & Possible fracture \\
\hline 351.9 & 137 & 57 & Possible fracture \\
\hline 354.3 & 256 & 38 & Possible fracture \\
\hline 355.2 & 248 & 41 & Possible fracture \\
\hline 358.4 & 215 & 37 & Possible fracture \\
\hline 358.7 & 215 & 42 & Possible fracture \\
\hline 362.2 & 120 & 82 & Possible fracture \\
\hline 364.7 & 211 & 41 & Possible fracture \\
\hline 364.7 & 211 & 41 & Possible fracture \\
\hline \multicolumn{4}{|c|}{$W-3$} \\
\hline $\begin{array}{l}\text { Midpoint } \\
\text { depth, } \\
\text { (in feet) }\end{array}$ & $\begin{array}{c}\text { Strike } \\
\text { (degrees) }\end{array}$ & $\begin{array}{c}\text { Dip } \\
\text { (degrees) }\end{array}$ & Comments \\
\hline
\end{tabular}

\begin{tabular}{|c|c|c|c|}
\hline \multicolumn{4}{|c|}{ W-3-Continued } \\
\hline $\begin{array}{l}\text { Midpoint } \\
\text { depth, } \\
\text { (in feet) }\end{array}$ & $\begin{array}{c}\text { Strike } \\
\text { (degrees) }\end{array}$ & $\begin{array}{c}\text { Dip } \\
\text { (degrees) }\end{array}$ & Comments \\
\hline
\end{tabular}

\begin{tabular}{rlll}
\hline \multicolumn{4}{c}{ Fractures (code 2)--Continued } \\
150.9 & 340 & 56 & Fracture \\
159.3 & 327 & 51 & Fracture \\
170.0 & 332 & 47 & Fracture \\
189.2 & 333 & 65 & Fracture \\
191.2 & 343 & 58 & Fracture \\
210.3 & 339 & 53 & Fracture \\
226.1 & 351 & 66 & Fracture \\
257.4 & 348 & 62 & Fracture \\
401.5 & 340 & 76 & Fracture \\
405.7 & 323 & 58 & Fracture \\
440.0 & 295 & 26 & Fracture \\
464.1 & 352 & 81 & Fracture \\
533.2 & 349 & 64 & Fracture \\
542.7 & 310 & 40 & Fracture \\
549.8 & 324 & 46 & Fracture \\
550.1 & 289 & 23 & Fracture \\
& \multicolumn{3}{c}{ Possible fractures (code 3) } \\
39.6 & 299 & 23 & Possible fracture \\
53.9 & 285 & 11 & Possible fracture \\
187.6 & 347 & 64 & Possible fracture \\
200.9 & 325 & 38 & Possible fracture \\
288.1 & 288 & 7 & Possible fracture \\
511.9 & 289 & 19 & Possible fracture \\
550.6 & 284 & 16 & Possible fracture at bottom of \\
& \multicolumn{4}{|c}{ hole } \\
\hline 5
\end{tabular}

\begin{tabular}{rrrl} 
& \multicolumn{3}{c}{ Major fractures (code 1) } \\
168.6 & 338 & 60 & Wide fracture \\
168.9 & 338 & 55 & Top of wide fracture zone \\
178.7 & 337 & 54 & Bottom of wide fracture zone \\
180.3 & 332 & 49 & Top of wide fracture zone \\
184.4 & 340 & 29 & Bottom of wide fracture zone \\
259.0 & 342 & 55 & Wide fracture \\
537.7 & 340 & 54 & Wide fracture \\
550.4 & 292 & 17 & Wide fracture \\
& \multicolumn{3}{c}{ Fractures (code 2) } \\
28.3 & 276 & 3 & Fracture \\
29.2 & 278 & 3 & Fracture \\
51.3 & 320 & 45 & Fracture \\
69.1 & 326 & 51 & Fracture \\
83.2 & 330 & 56 & Fracture \\
90.6 & 317 & 40 & Fracture \\
122.7 & 343 & 70 & Fracture \\
& \multicolumn{3}{|}{}
\end{tabular}

\begin{tabular}{cccc}
\hline & \multicolumn{3}{c}{ W-4 } \\
\hline $\begin{array}{c}\text { Midpoint } \\
\text { depth, } \\
\text { (in feet) }\end{array}$ & $\begin{array}{c}\text { Strike } \\
\text { (degrees) }\end{array}$ & $\begin{array}{c}\text { Dip } \\
\text { (degrees) }\end{array}$ & Comments \\
\hline
\end{tabular}

\begin{tabular}{rrrl}
\hline 55.1 & 305 & Major fractures (code 1) \\
55.8 & 28 & 7 & Bottom of wide fracture \\
73.8 & 316 & 10 & Bottom of wide fracture \\
85.6 & 274 & 14 & Bottom of wide fracture \\
96.5 & 274 & 25 & Top of wide fracture zone \\
97.3 & 294 & 3 & Bottom of wide fracture zone \\
110.2 & 330 & 12 & Bottom of wide fracture zone \\
140.9 & 321 & 17 & Bottom of wide fracture zone \\
227.4 & 300 & 24 & Wide fracture \\
240.9 & 136 & 61 & Top of wide fracture zone \\
251.0 & 162 & 64 & Top of wide fracture zone \\
252.1 & 164 & 64 & Bottom of wide fracture zone \\
288.9 & 73 & 32 & Top of wide fracture
\end{tabular}


Table 1. Midpoint depth, strike, and dip of fractures identified in wells TBR-1, TBR-2, TBR-3, W-3, W-4, and W-5, by acoustic televiewer in Rye, New Hampshire--Continued

\begin{tabular}{|c|c|c|c|c|c|c|c|}
\hline \multicolumn{4}{|c|}{ W-4-Continued } & \multicolumn{4}{|c|}{ W-5-Continued } \\
\hline $\begin{array}{l}\text { Midpoint } \\
\text { depth, } \\
\text { (in feet) }\end{array}$ & $\begin{array}{c}\text { Strike } \\
\text { (degrees) }\end{array}$ & $\begin{array}{c}\text { Dip } \\
\text { (degrees) }\end{array}$ & Comments & $\begin{array}{l}\text { Midpoint } \\
\text { depth, } \\
\text { (in feet) }\end{array}$ & $\begin{array}{c}\text { Strike } \\
\text { (degrees) }\end{array}$ & $\begin{array}{c}\text { Dip } \\
\text { (degrees) }\end{array}$ & Comments \\
\hline \multicolumn{4}{|c|}{ Fractures (code 2) } & \multicolumn{4}{|c|}{ Fractures (code 2)--Continued } \\
\hline 38.8 & 304 & 13 & Fracture & 175.6 & 47 & 45 & Fracture \\
\hline 61.0 & 4 & 66 & Fracture & 181.3 & 197 & 38 & Fracture \\
\hline 79.9 & 329 & 23 & Fracture & 198.8 & 18 & 33 & Fracture \\
\hline 82.8 & 97 & 85 & Partial, vertical fracture & 226.9 & 233 & 19 & Fracture \\
\hline 114.3 & 322 & 13 & Fracture & 232.8 & 335 & 17 & Fracture \\
\hline 115.2 & 158 & 67 & Fracture & 237.2 & 221 & 8 & Fracture \\
\hline 117.6 & 201 & 47 & Fracture & 238.7 & 128 & 55 & Fracture \\
\hline 129.4 & 5 & 58 & Fracture & 246.3 & 213 & 55 & Fracture \\
\hline 168.6 & 218 & 18 & Fracture & 252.3 & 338 & 8 & Fracture \\
\hline 195.8 & 343 & 38 & Fracture & 258.7 & 205 & 74 & Fracture \\
\hline 196.4 & 337 & 40 & Fracture & 259.3 & 224 & 73 & Fracture \\
\hline 235.5 & 234 & 57 & Fracture & 287.8 & 308 & 47 & Fracture \\
\hline 245.4 & 172 & 56 & Fracture & 316.5 & 132 & 71 & Fracture \\
\hline 247.4 & 184 & 58 & Fracture & 326.0 & 337 & 3 & Fracture \\
\hline 250.0 & 150 & 59 & Fracture & 336.2 & 332 & 14 & Fracture \\
\hline 270.7 & 248 & 78 & Faint fracture & 355.7 & 349 & 21 & Fracture \\
\hline 276.3 & 13 & 69 & Fracture & 361.7 & 176 & 74 & Fracture \\
\hline 284.6 & 281 & 78 & Fracture & 370.1 & 343 & 29 & Fracture \\
\hline \multicolumn{4}{|c|}{ Possibie fractures (code 3) } & 375.9 & 200 & 40 & Fracture \\
\hline 150.6 & 325 & 42 & Possible fracture & 377.3 & 320 & 23 & Fracture \\
\hline 285.3 & 73 & 43 & Possible fracture & 377.7 & 348 & 19 & Fracture \\
\hline 222.3 & 340 & 16 & Fracture or lithologic contact & 381.6 & 319 & 24 & Fracture \\
\hline \multicolumn{4}{|c|}{ W-5 } & 383.1 & 351 & 24 & Fracture \\
\hline Midpoint & & & & 386.3 & 19 & & \\
\hline depth, & (dearees) & (dearees) & Comments & \multicolumn{4}{|c|}{ Possible fractures (code 3 ) } \\
\hline (in feet) & & & & $1 / 0.9$ & 21 & 16 & Possible iracture \\
\hline \multicolumn{4}{|c|}{ Major fractures (code 1) } & $\begin{array}{l}242.5 \\
2540\end{array}$ & $\begin{array}{r}201 \\
70\end{array}$ & 60 & Possible fracture \\
\hline 160.4 & 242 & 43 & Wide fracture & 254.0 & 19 & 08 & Possible fracture \\
\hline 166.0 & 69 & 31 & Wide fracture & 279.2 & 156 & 49 & Possible fracture \\
\hline 213.9 & 208 & 58 & Wide fracture & 280.3 & 141 & 48 & Possible fracture \\
\hline 234.0 & 74 & 0 & Top of wide fracture & 284.8 & 169 & 8 & Possible fracture \\
\hline 235.4 & 74 & 0 & Bottom of wide fracture & 291.9 & 266 & 39 & Possible fracture \\
\hline 241.5 & 203 & 63 & Top of wide fracture & 322.1 & 244 & 15 & Possible fracture \\
\hline 243.8 & 153 & 15 & Bottom of wide fracture & 355.2 & 23 & 34 & Possible fracture \\
\hline 248.0 & 204 & 41 & Top of wide fracture & 363.0 & 123 & 63 & Possible fracture \\
\hline 248.1 & 204 & 39 & Bottom of wide fracture & 363.7 & 121 & 58 & Possible fracture \\
\hline 393.0 & - & -- & Fracture zone & 365.2 & 251 & 59 & Possible fracture \\
\hline \multicolumn{4}{|c|}{ Fractures (code 2) } & 365.5 & 247 & 55 & Possible fracture \\
\hline 332.9 & 158 & 2 & Fracture here & 376.9 & 183 & 7 & Possible fracture \\
\hline & & & -approximate strike and dip & 390.1 & 196 & 74 & Possible fracture \\
\hline 154.8 & 341 & 64 & Fracture & & & & \\
\hline
\end{tabular}


Fracture plane (shown to

strike approximately $\mathrm{N} 215^{\circ} \mathrm{E}$ and

$\operatorname{dip} 80^{\circ}$ to the west)

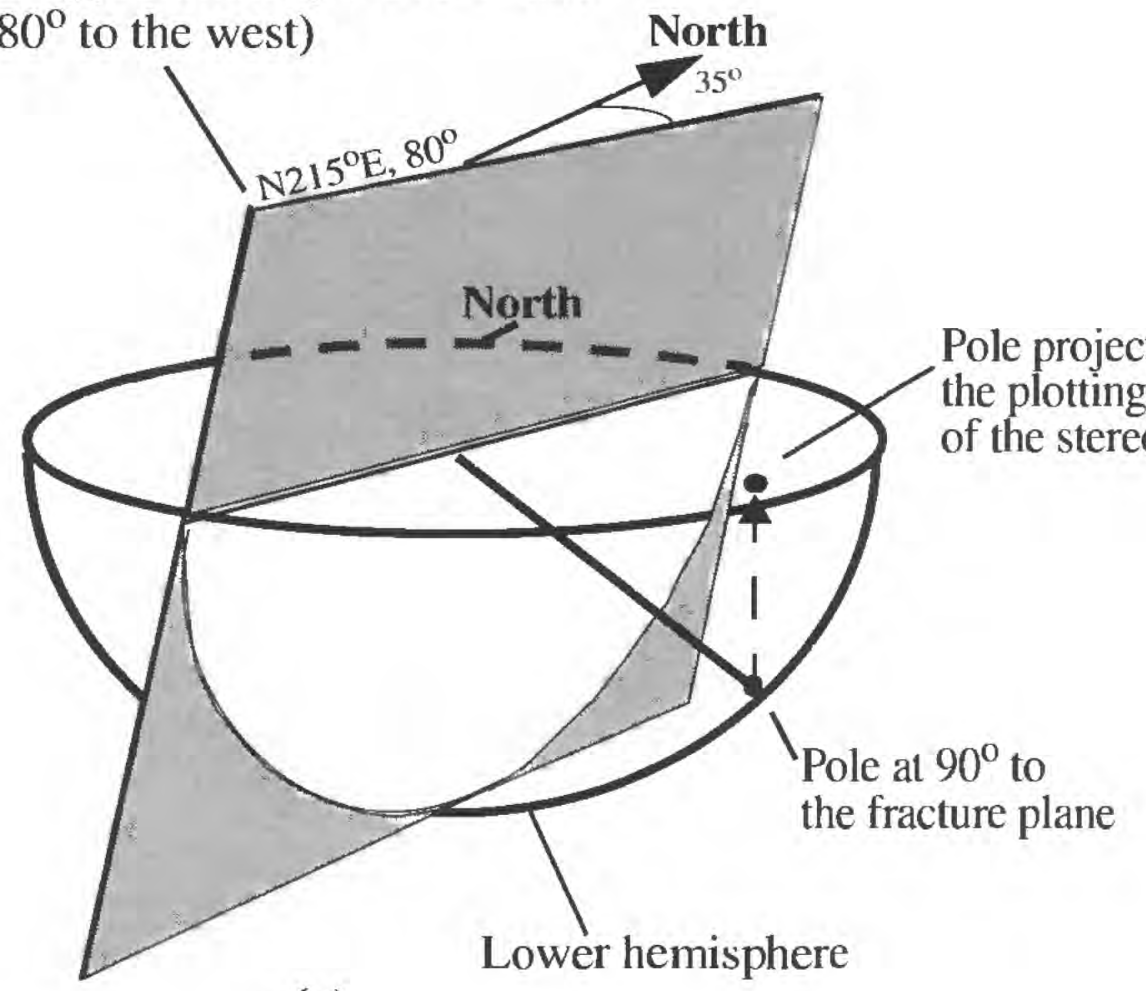

(a)

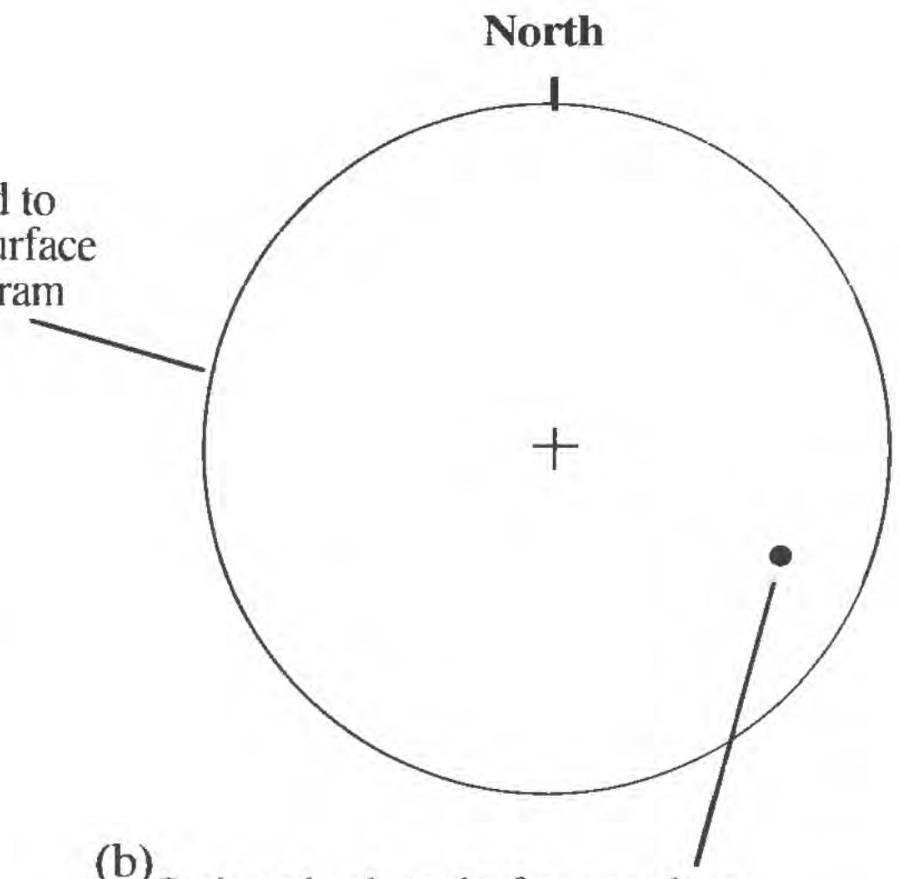

(b) Projected pole to the fracture plane

plotted on a lower hemisphere, equal-area projection.

Figure 11. Schematic diagram of stereographic projections. The stereographic projection reduces the orientation of a fracture plane to a point on a stereogram by plotting the pole to the plane on a lower hemisphere and projecting it up to the plotting surface of the stereogram. The schematic (a) shows a three-dimensional representation of the fracture plane as it intersects the hemisphere and the projected pole to the plane, and (b) shows the stereogram that would correspond to example (a).

An eigenvalue that is close to one indicates a unimodal set of planes that is closely parallel to the eigenvector and could adequately be described by a mean vector. The magnitudes of the eigenvectors are used to determine if the fracture sets are statistically significant. An eigenvalue close to zero indicates an insignificant eigenvector with only a minimal amount of poles associated with it. For each well, the results of the analyses, including the mean vector, eigenvalue, and eigenvector are listed in table 2 for each fracture type and for all of the fracture types combined. The eigenvectors were generated using StereoNett software developed by Johannes Duyster at the Institute for Geology, Ruhr-University Borchum, Germany.

A comparison of the eigenvalues and eigenvectors for the wide fractures and fractures in TBR-1 and TBR-3 indicates there is a strong component of fractures that strike $\mathrm{N} 171^{\circ} \mathrm{E}$ to $\mathrm{N} 203^{\circ} \mathrm{E}$ and dip from 32 to $70^{\circ}$ to the west. These features are similar in strike to the lineaments determined in the high- and low-aerial photography that are mapped to the west of the wells (fig. 1) and trend approximately $\mathrm{N} 165^{\circ} \mathrm{E}$ and $\mathrm{N} 169^{\circ} \mathrm{E}$.

Well TBR-2 has a high proportion (eigenvalue $=$ 0.556 ) of "wide fractures" ( code $=1$ ) that follows the same direction $\left(\mathrm{N} 185^{\circ} \mathrm{E}\right.$, dipping $62^{\circ} \mathrm{W}$ ). However, the "fractures" (code $=2$ ) in TBR-2 have a dominant orientation of $\mathrm{N} 320^{\circ} \mathrm{E}$, dipping $74^{\circ}(\mathrm{N}-\mathrm{NE})$, which is parallel to the SLAR feature that is labeled $\mathrm{N} 140^{\circ} \mathrm{E}$ (fig. 1). If these are coincident, it would imply that this SLAR feature dips northeast.

Well W-3 has a strongly clustered set of poles (eigenvalue $=0.910$ ) about a plane oriented at $\mathrm{N} 313^{\circ} \mathrm{E}$, dipping $49^{\circ}(\mathrm{N}-\mathrm{NE})$ for the "wide fractures." and an eigenvalue of 0.850 at $\mathrm{N} 307^{\circ} \mathrm{E}, 54^{\circ}(\mathrm{NE})$ for "fractures." The dominant fracture planes in W-3 are nearly parallel to the fractures observed in TBR-2, as well as the SLAR feature that is trending $N 140^{\circ} \mathrm{E}$. 
(a)

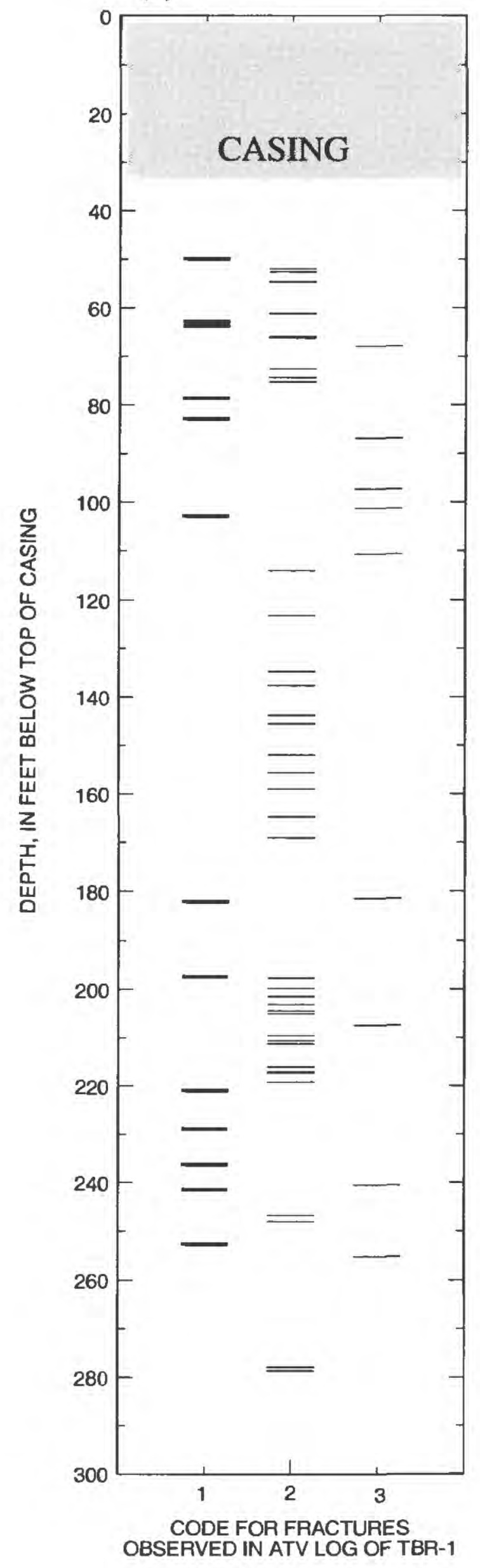

True North

(b)

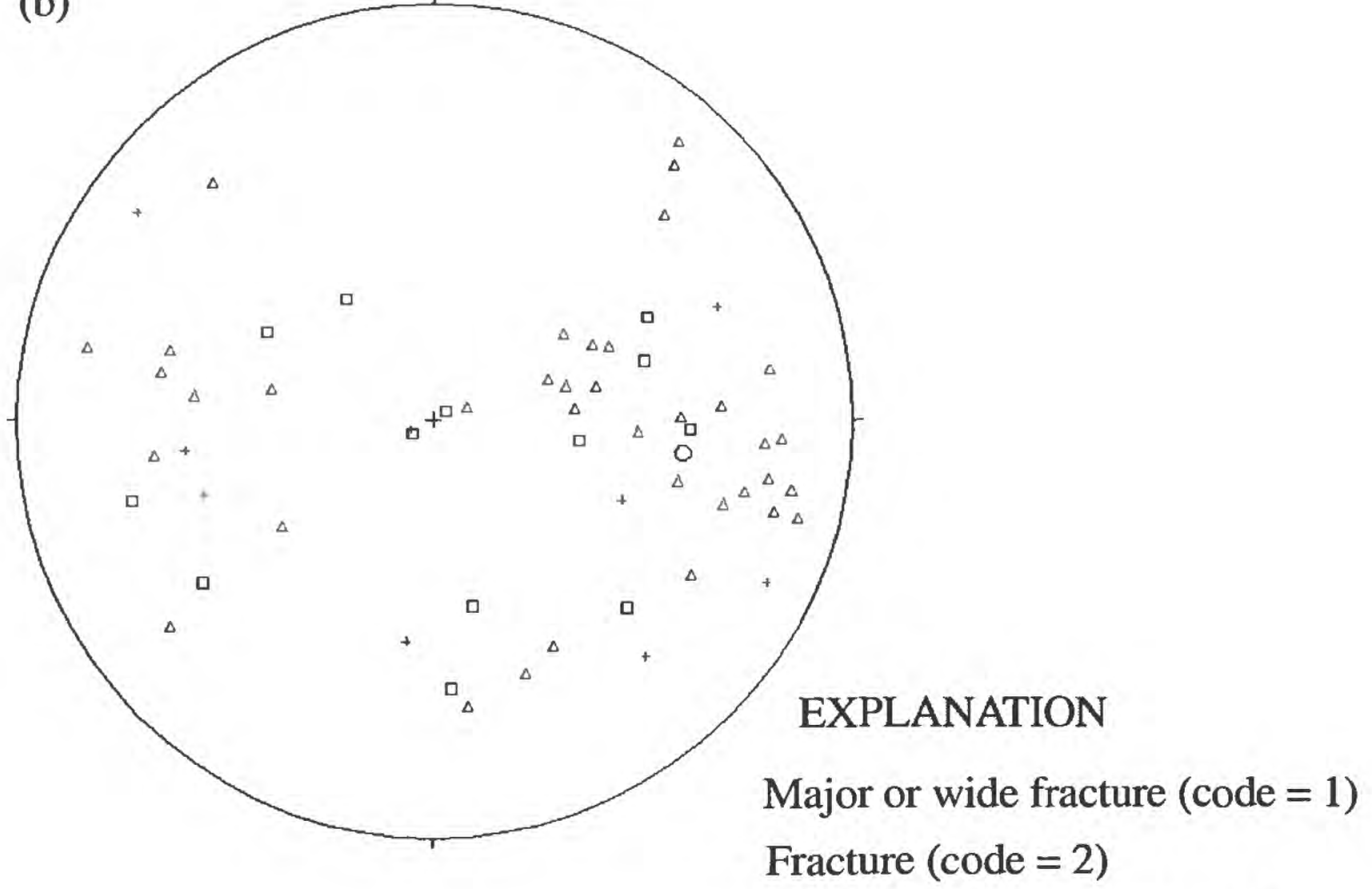

Possible fractures $($ code $=3$ )

(c)

Mean pole

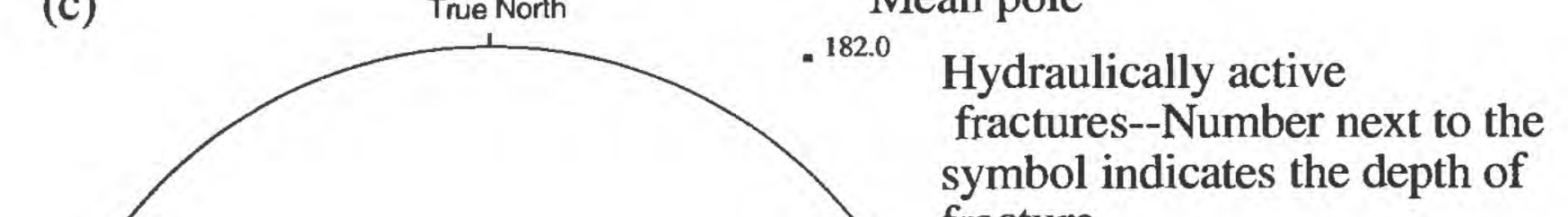
fracture

Figure 12. Location and orientation of fractures observed in acoustic televiewer (ATV) log of well TBR-1, in Rye, New Hampshire shows the (a) depths and fracture code, (b) lower-hemisphere equal-area projection (stereogram) of fracture poles for all fractures (the symbol indicates the fracture code), and (c) stereogram of hydraulically active fractures. 
(a)

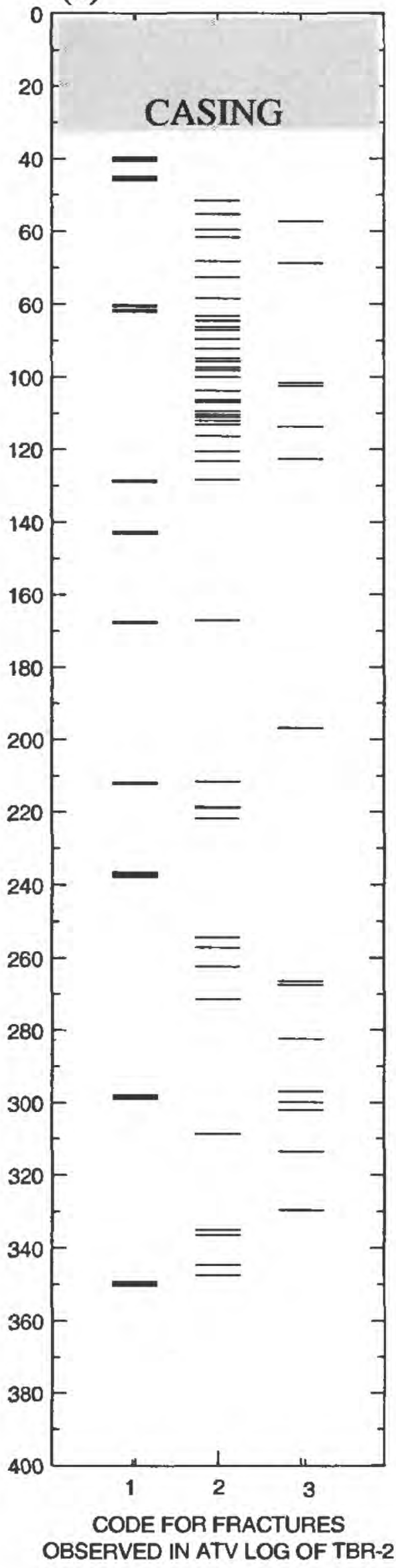

(b)

True North

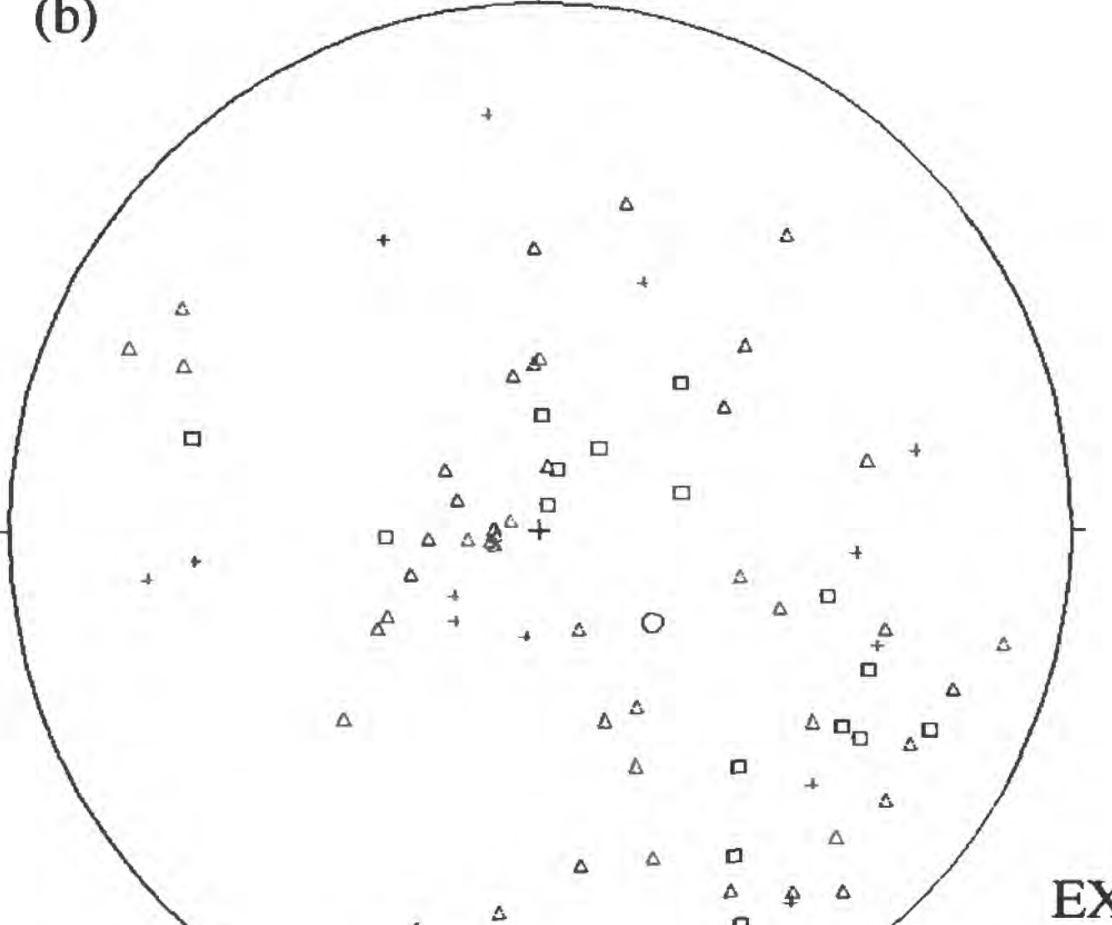

EXPLANATION

- Major or wide fracture (code $=1)$

$\triangle \quad$ Fracture $($ code $=2)$

+ Possible fractures (code $=3$ )

(c)

- Mean pole

Hydraulically active fractures--Number next to the symbol indicates the depth of fracture

Figure 13. Location and onentation of fractures observed in acoustic televiewer (ATV) log of well TBR-2, in Rye, New Hampshire shows the (a) depths and fracture code, (b) lower-hemisphere equal-area projection (stereogram) of fracture poles for all fractures (the symbol indicates the fracture code), and (c) stereogram of hydraulically active fractures. 
(a)

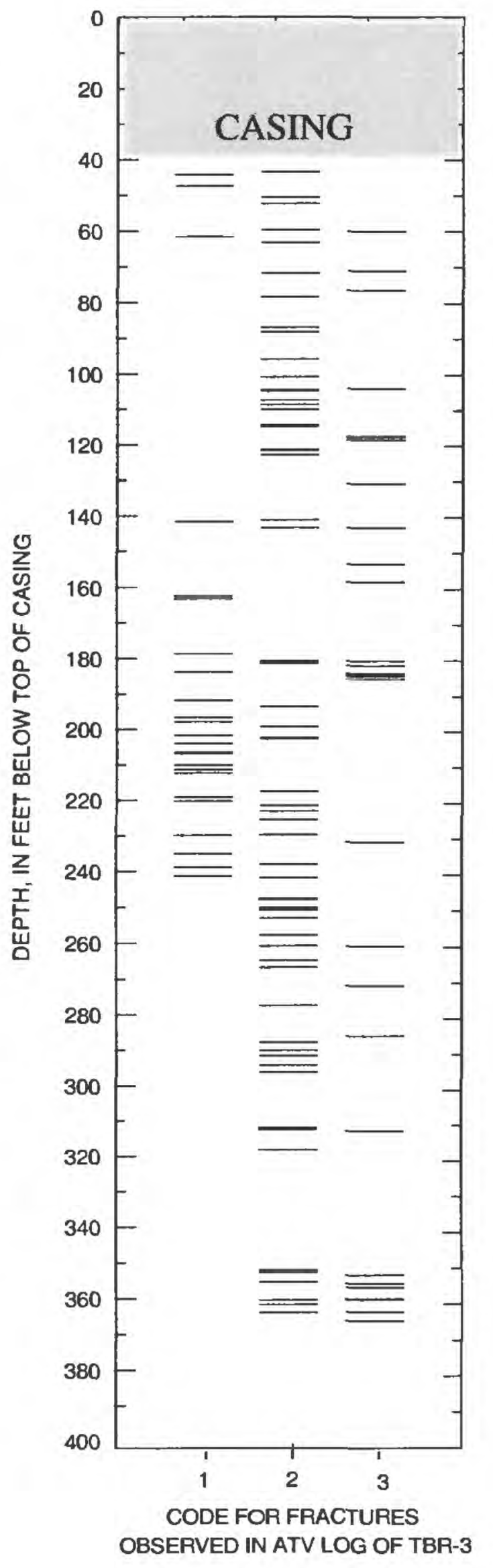

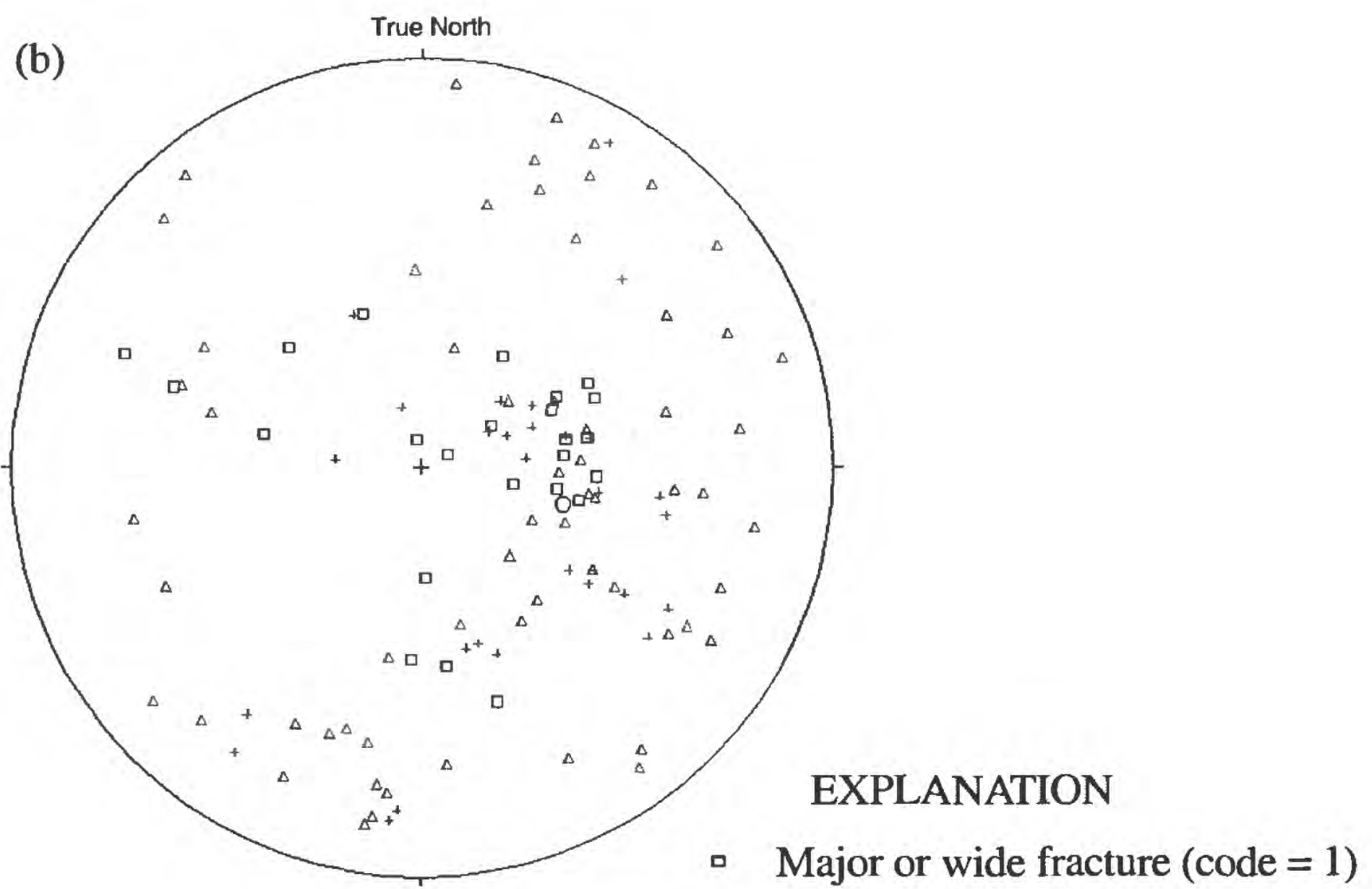

$\triangle \quad$ Fracture (code $=2$ )

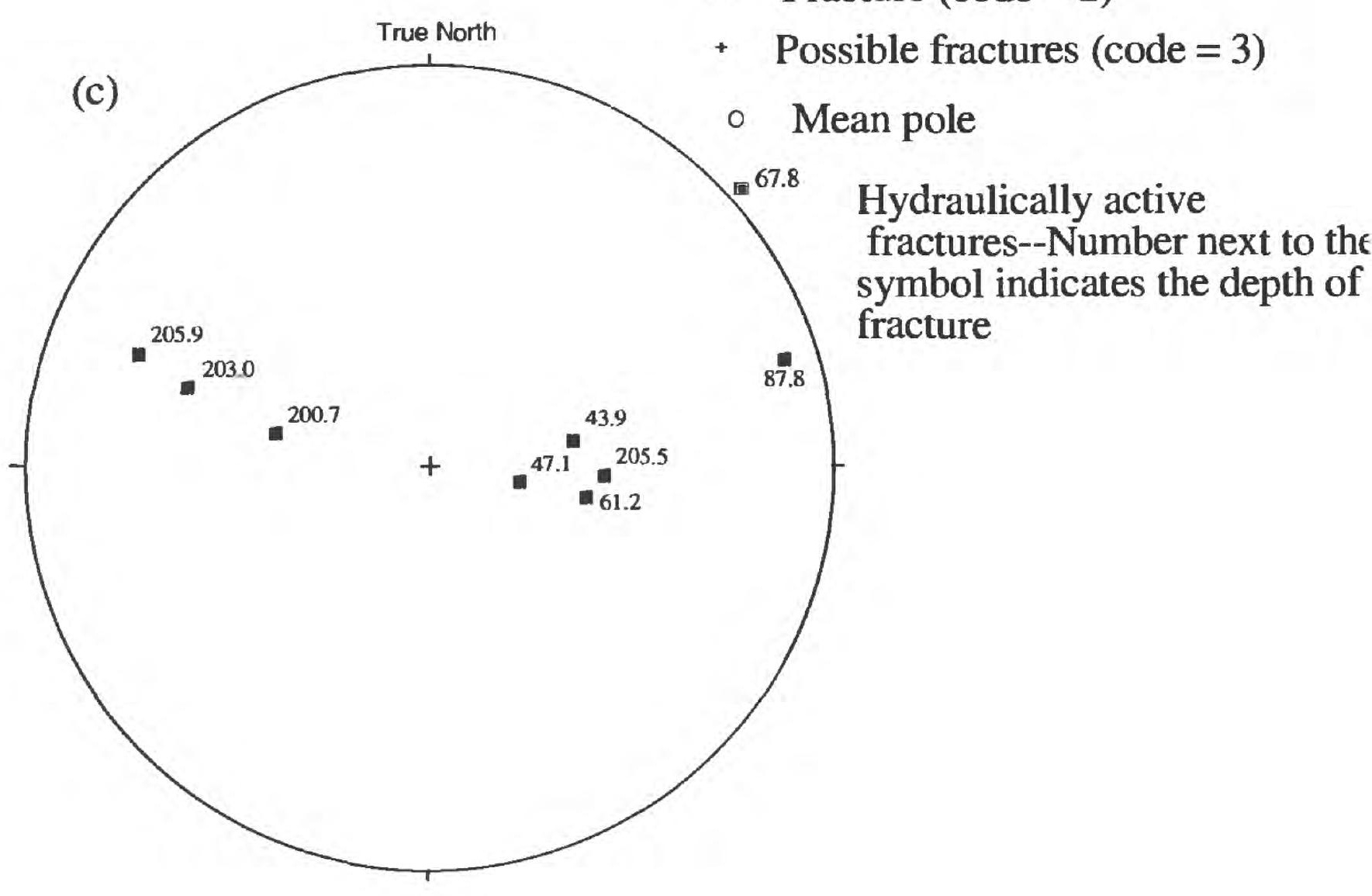

Figure 14. Location and orientation of fractures observed in acoustic televiewer (ATV) log of well TBR-3, in Rye, New Hampshire shows the (a) depths and fracture code, (b) lower-hemisphere equal-area projection (stereogram) of fracture poles for all fractures (the symbol indicates the fracture code), and (c) stereogram of hydraulically active fractures. 
(a)

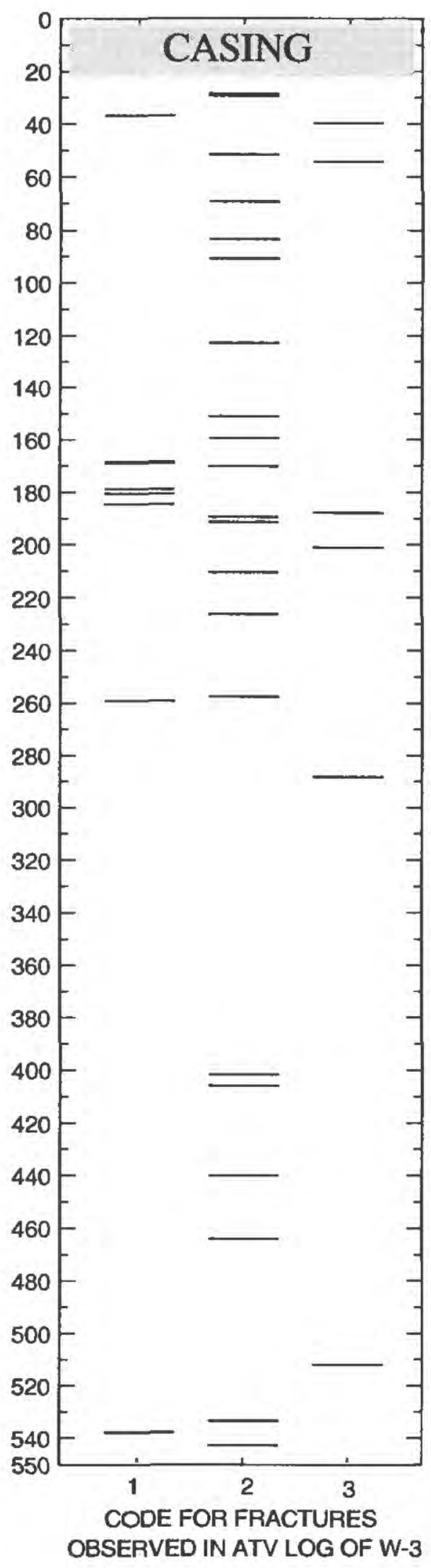

(b)

True North

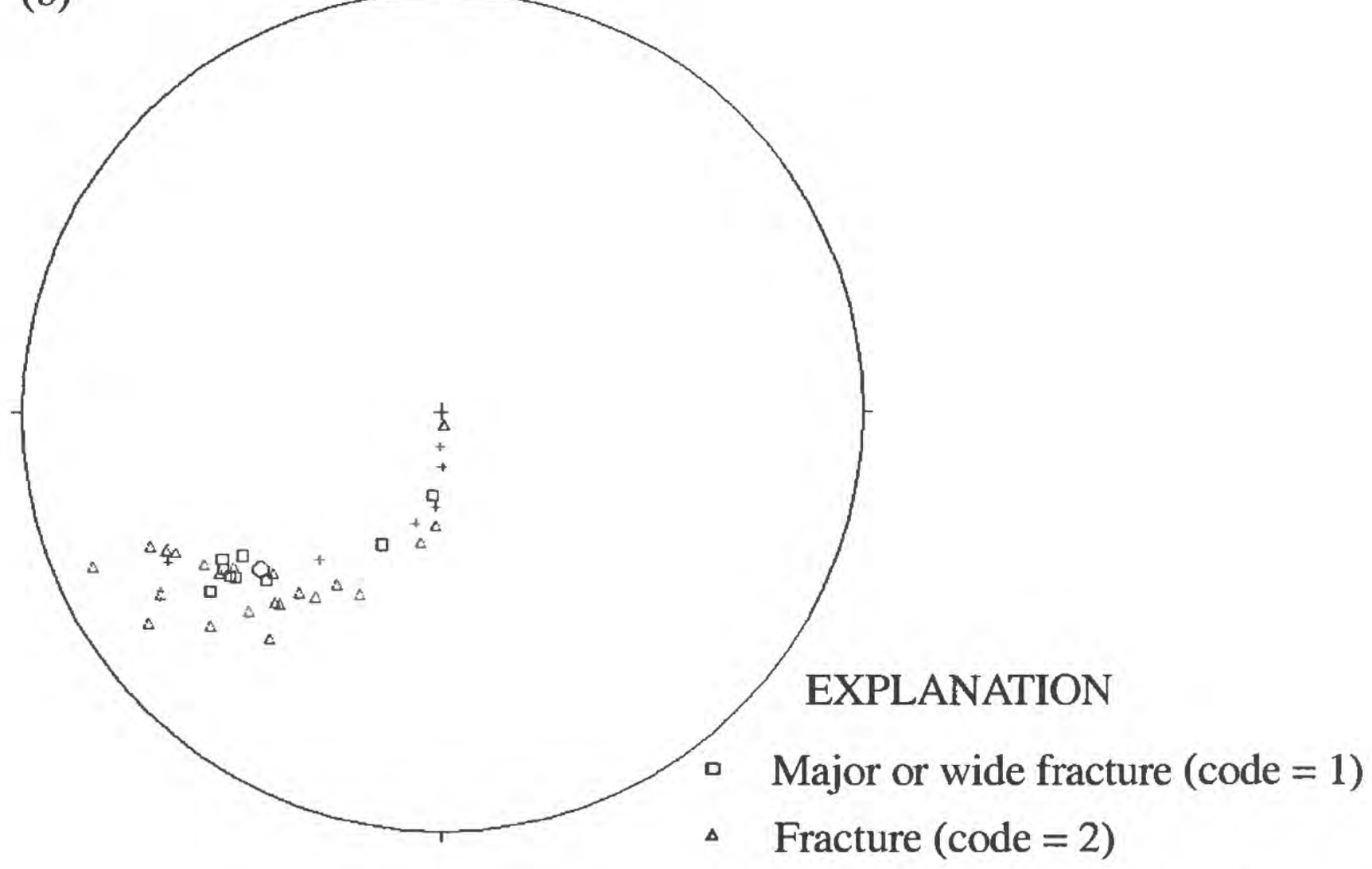

+ Possible fractures (code $=3$ )

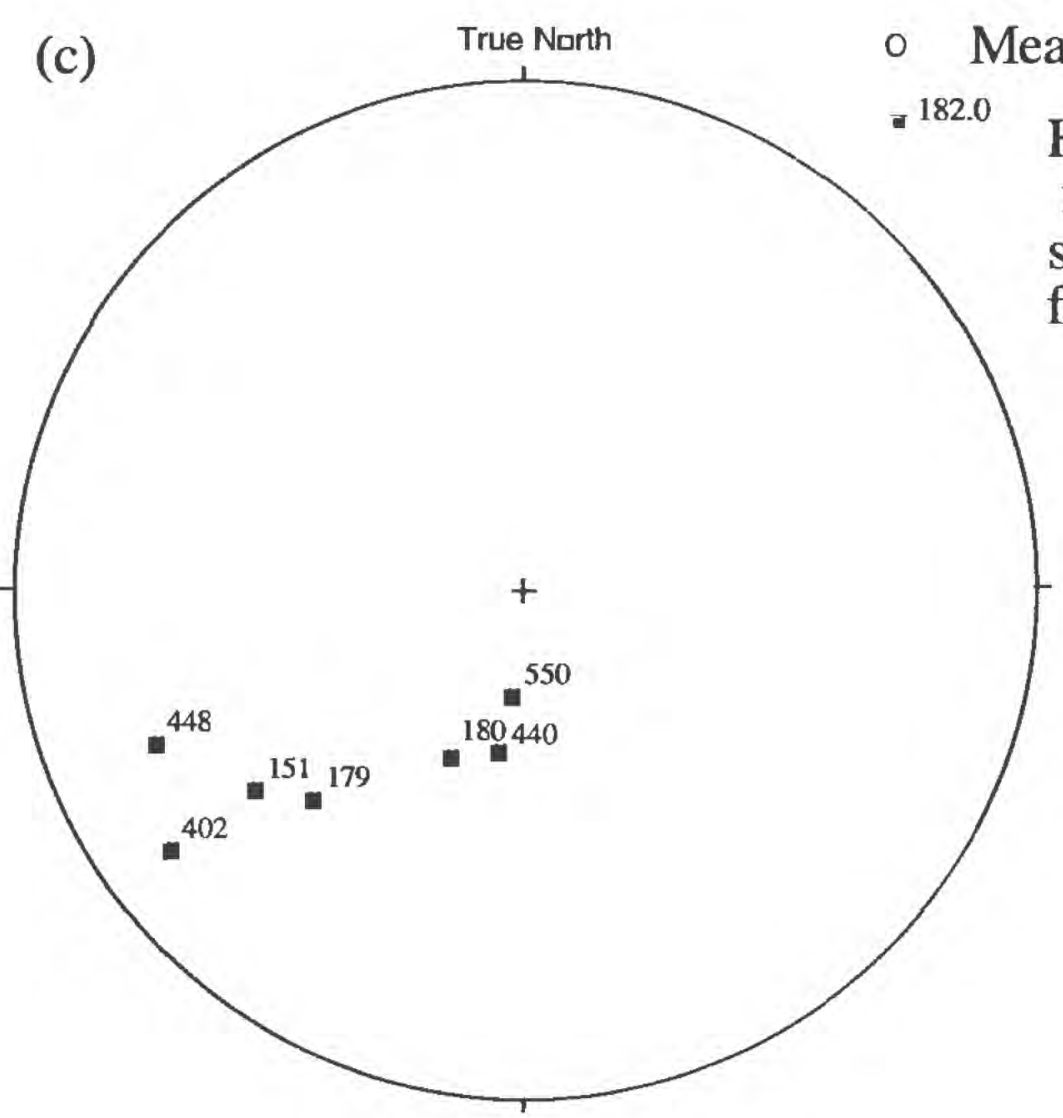

Figure 15. Location and onentation of fractures observed in acoustic televiewer (ATV) log of well W-3, in Rye, New Hampshire shows the (a) depths and fracture code, (b) lower-hemisphere equal-area projection (stereogram) of fracture poles for all fractures (the symbol indicates the fracture code), and (c) stereogram of hydraulically active fractures. 
(a)

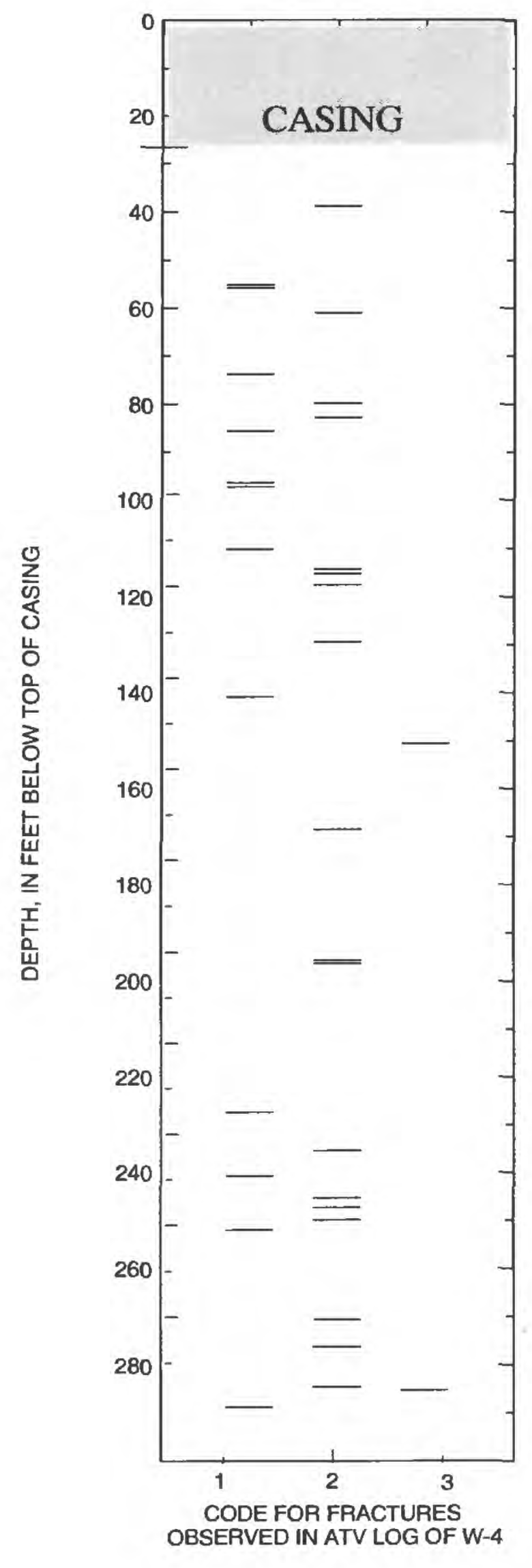

(b)

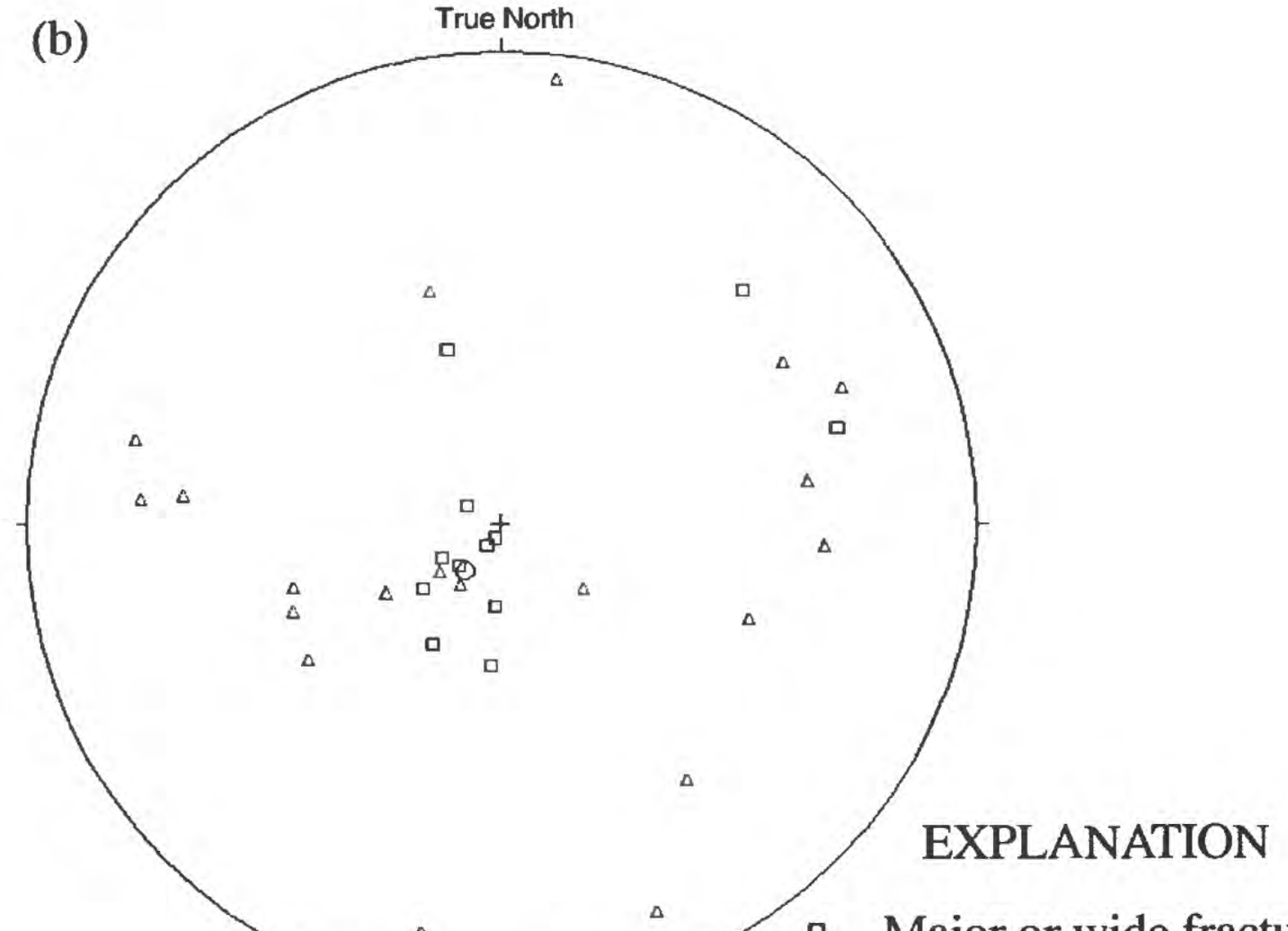

- Major or wide fracture (code $=1)$

$\triangle \quad$ Fracture $($ code $=2)$

+ Possible fractures (code $=3$ )

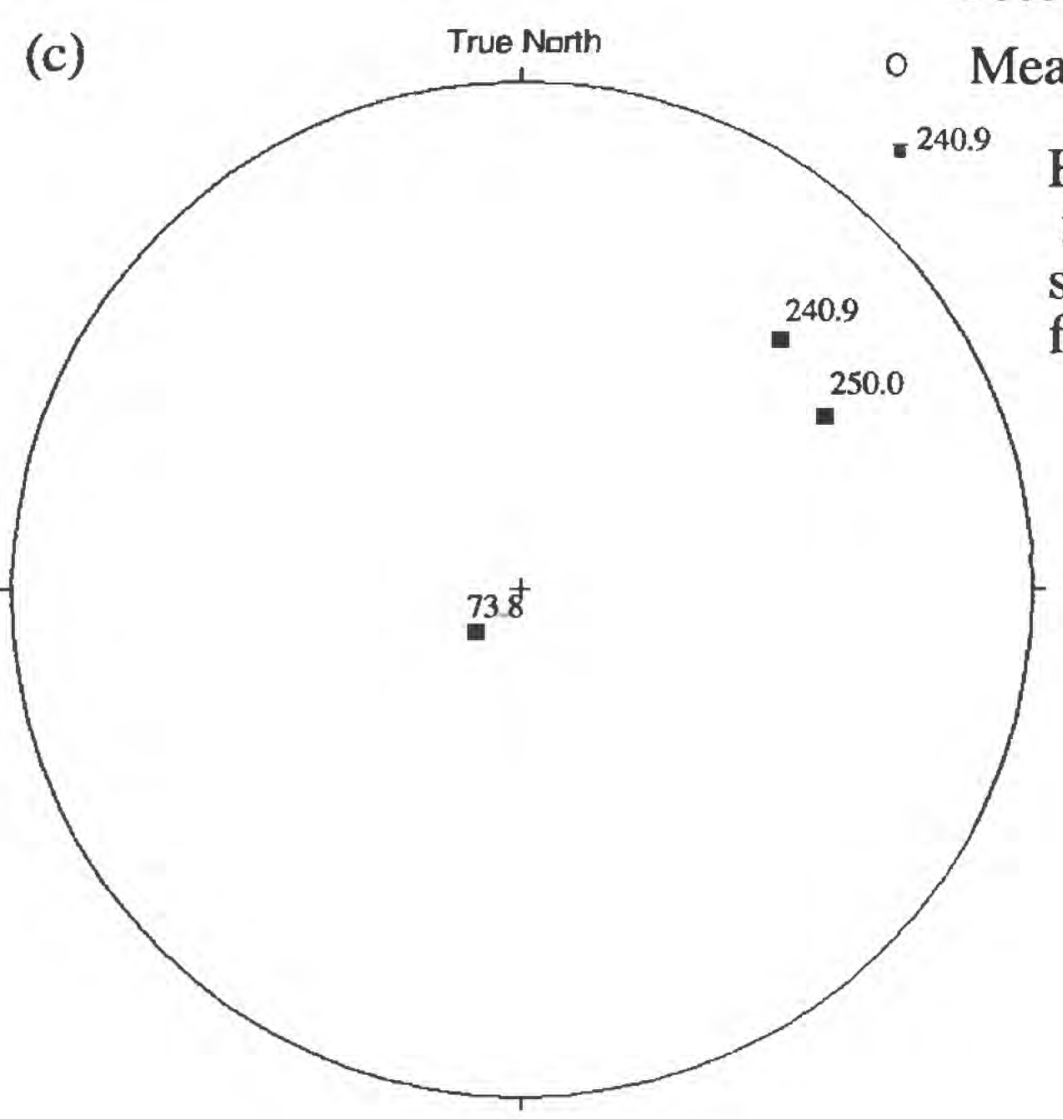

Hydraulically active fractures--Number next to the symbol indicates the depth of fracture

Figure 16. Location and orientation of fractures observed in acoustic televiewer (ATV) log of well W-4, in Rye, New Hampshire shows the (a) depths and fracture code, (b) lower-hemisphere equal-area projection (stereogram) of fracture poles for all fractures (the symbol indicates the fracture code), and (c) stereogram of hydraulically active fractures. 
(a)

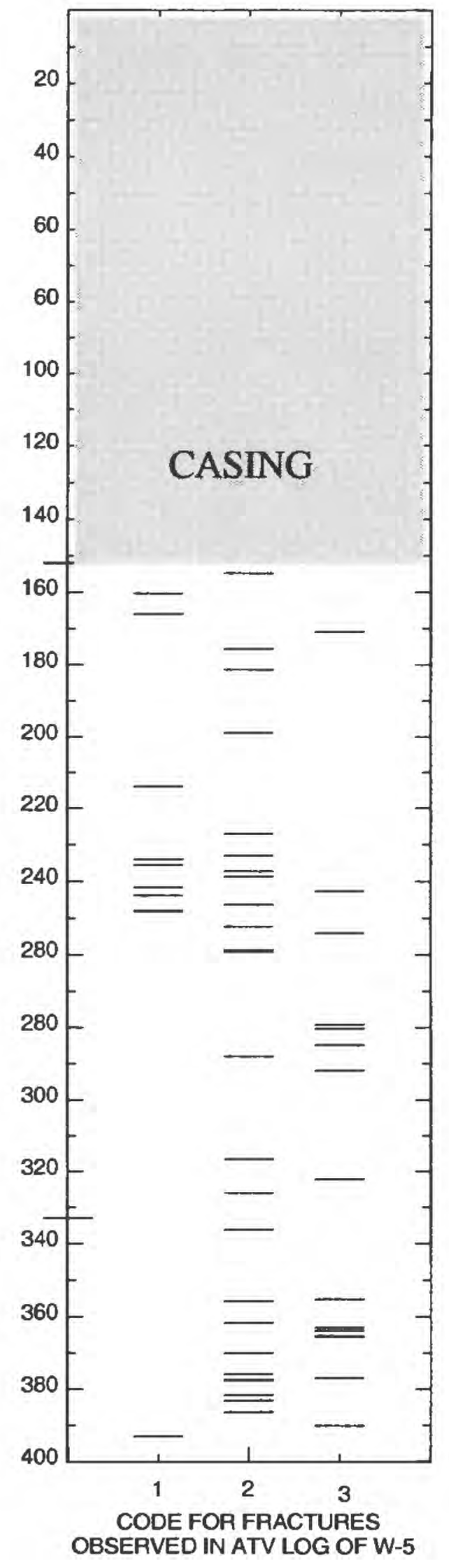

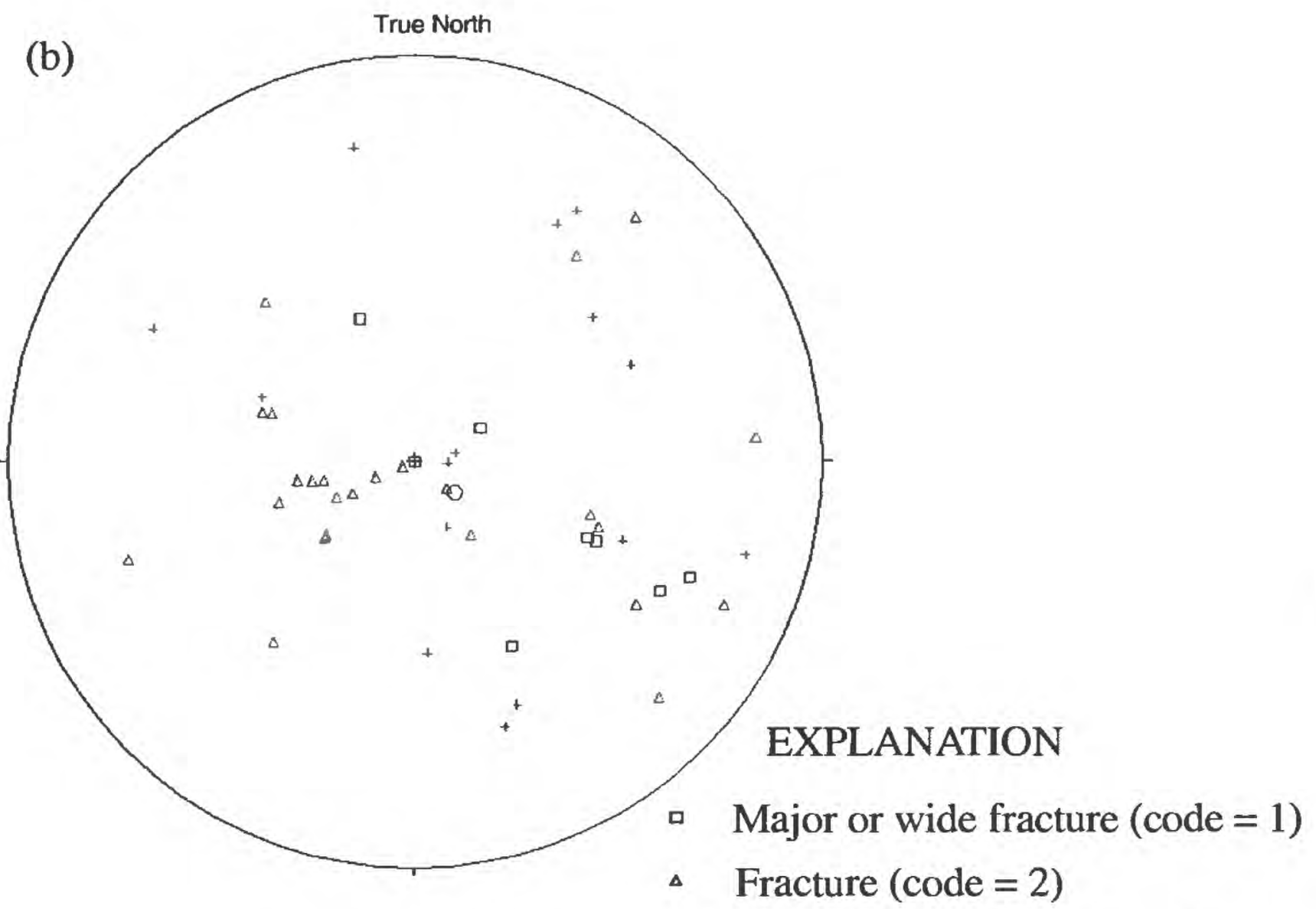

+ Possible fractures (code $=3$ )

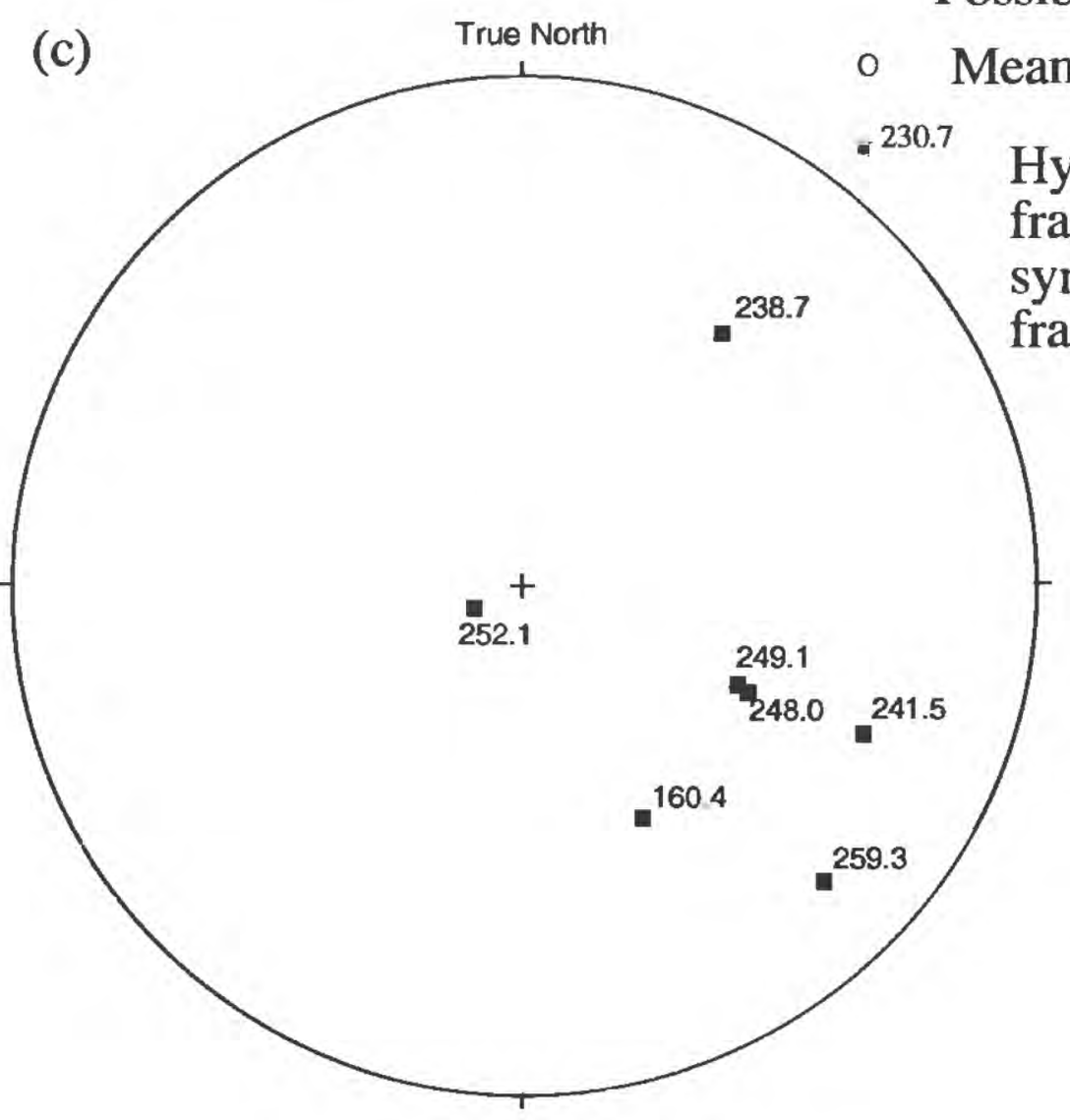

Figure 17. Location and orientation of fractures observed in acoustic televiewer (ATV) log of well W-5, in Rye, New Hampshire shows the (a) depths and fracture code, (b) lower-hemisphere equal-area projection (stereogram) of fracture poles for all fractures (the symbol indicates the fracture code), and (c) stereogram of hydraulically active fractures. 


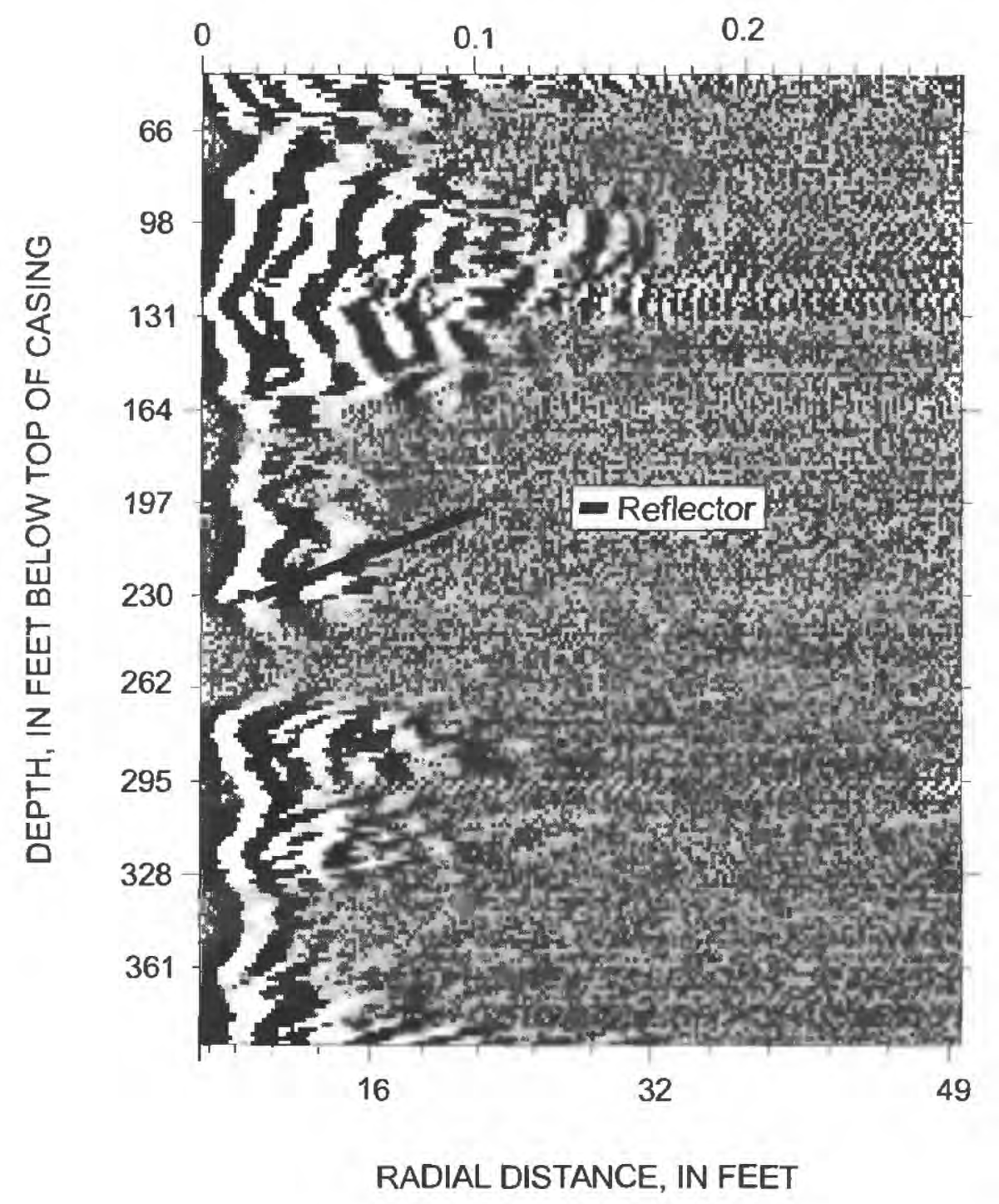

Figure 18. Unprocessed borehole-radar log of well TBR-2 in Rye, New Hampshire.

Well W-4 exhibits an eigenvector that strikes $\mathrm{N} 301^{\circ} \mathrm{E}$, for "wide fractures". However, the dip of the eigenvector is shallow, $8^{\circ}(\mathrm{NE})$. A shallow dipping feature would not be expected to correlate with the lineaments. The "fractures" in well W-4 are clustered about a plane with an eigenvalue of 0.607 and an

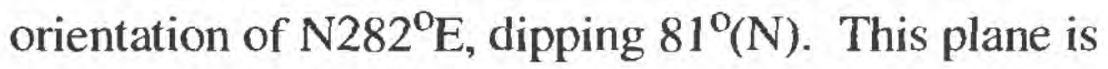
parallel to the SLAR feature that strikes $\mathrm{N} 100^{\circ} \mathrm{E}$ (or $\mathrm{N} 280^{\circ} \mathrm{E}$ ). The interpretation of the ATV data implies that this SLAR feature is dipping North.

A pattern also emerges from the eigenvector analysis of well W-5. The "wide fractures" identified in W-5 were found to have two significant fracture sets. The dominant set had an eigenvalue of 0.622 for a plane oriented at $\mathrm{N} 221^{\circ} \mathrm{E}$, dipping $38^{\circ}(\mathrm{NW})$, which coincides with the low altitude feature $\left(\mathrm{N} 40^{\circ} \mathrm{E}\right)$. The second set had an eigenvalue of 0.30 for a plane at $\mathrm{N} 100^{\circ} \mathrm{E}$, dipping $33^{\circ}(\mathrm{S})$, which is parallel to the SLAR feature trending $N 100^{\circ} \mathrm{E}$ that passes south of the well and with the orientation of Bailey Brook (fig. 1). The code-2 fractures had two significant fracture sets. The dominant set had an eigenvector of $\mathrm{N} 347^{\circ} \mathrm{E}$, dipping $29^{\circ}(\mathrm{E})$ and an eigenvalue of 0.520 , which is parallel to the high and low-altitude features trending $\mathrm{N} 165^{\circ} \mathrm{E}$ and $\mathrm{N} 169^{\circ} \mathrm{E}$. A feature with a shallow dip, however, would not likely be visible from aerial photos. The second set has an eigenvalue of 0.348 at a vector of $N 195^{\circ} \mathrm{E}$, dipping $58^{\circ}(\mathrm{W})$, which is 
Table 2. Statistical summary of fracture type and orientations for wells TBR-1, TBR-2, TBR-3, W-3, W-4, and W-5 in Rye, New Hampshire

[Fracture code 1 refers to a wide fracture; code 2 is a fracture; and code 3 is a possible fracture; All refers to all fractures (codes 1,2, and 3)]

\begin{tabular}{|c|c|c|c|c|c|c|c|c|c|c|c|c|c|c|c|}
\hline \multirow{2}{*}{ Well } & \multirow{2}{*}{$\begin{array}{l}\text { Frac- } \\
\text { ture } \\
\text { type } \\
\text { code }\end{array}$} & \multirow{2}{*}{$\begin{array}{l}\text { Num- } \\
\text { ber of } \\
\text { frac- } \\
\text { tures }\end{array}$} & \multicolumn{2}{|c|}{ Mean vector } & \multicolumn{2}{|c|}{ Eigenvector } & \multirow{2}{*}{$\begin{array}{l}\text { Eigen } \\
\text { value }\end{array}$} & \multirow{2}{*}{ Well } & \multirow{2}{*}{$\begin{array}{l}\text { Frac- } \\
\text { ture } \\
\text { type } \\
\text { code }\end{array}$} & \multirow{2}{*}{$\begin{array}{l}\text { Num- } \\
\text { ber of } \\
\text { frac- } \\
\text { tures }\end{array}$} & \multicolumn{2}{|c|}{ Mean vector } & \multicolumn{2}{|c|}{ Eigenvector } & \multirow{2}{*}{$\begin{array}{l}\text { Eigen } \\
\text { value }\end{array}$} \\
\hline & & & Strike & Dip & Strike & Dip & & & & & Strike & Dip & Strike & Dip & \\
\hline \multirow[t]{12}{*}{ TBR-1 } & 1 & 13 & 173 & 69 & 199 & 64 & 0.486 & W-3 & 1 & 9 & 311 & 48 & 313 & 49 & 0.910 \\
\hline & & & & & 340 & 21 & 0.340 & & & & & & 74 & 24 & 0.009 \\
\hline & & & & & 76 & 15 & 0.175 & & & & & & 180 & 30 & 0.002 \\
\hline & 2 & 37 & 176 & 73 & 178 & 70 & 0.697 & & 2 & 23 & 303 & 52 & 307 & 54 & 0.850 \\
\hline & & & & & 348 & 20 & 0.249 & & & & & & 75 & 24 & 0.137 \\
\hline & & & & & 79 & 3 & 0.001 & & & & & & 177 & 25 & 0.001 \\
\hline & 3 & 9 & 226 & 78 & 278 & 78 & 0.652 & & 3 & 6 & 284 & 28 & 283 & 26 & 0.825 \\
\hline & & & & & 171 & 4 & 0.277 & & & & & & 45 & 50 & 0.167 \\
\hline & & & & & 80 & 11 & 0.007 & & & & & & 178 & 30 & 0.007 \\
\hline & all & 59 & 180 & 73 & 188 & 72 & 0.633 & & all & 38 & 301 & 48 & 304 & 50 & 0.830 \\
\hline & & & & & 346 & 17 & 0.281 & & & & & & 73 & 28 & 0.158 \\
\hline & & & & & 80 & 6 & 0.009 & & & & & & 178 & 27 & 0.001 \\
\hline \multirow[t]{14}{*}{ TBR-2 } & 1 & 16 & 158 & 54 & 185 & 62 & 0.556 & W-4 & 1 & 12 & 307 & 2 & 301 & 8 & 0.615 \\
\hline & & & & & 291 & 9 & 0.303 & & & & & & 60 & 75 & 0.200 \\
\hline & & & & & 26 & 27 & 0.141 & & & & & & 209 & 13 & 0.188 \\
\hline & 2 & 47 & 321 & 78 & 320 & 74 & 0.494 & & 2 & 18 & 289 & 74 & 282 & 81 & 0.607 \\
\hline & & & & & 2 & 13 & 0.297 & & & & & & 164 & 4 & 0.301 \\
\hline & & & & & 94 & 8 & 0.208 & & & & & & 13 & 8 & 0.009 \\
\hline & 3 & 15 & 282 & 81 & 232 & 85 & 0.633 & & 3 & 2 & -- & -- & -- & -- & -- \\
\hline & & & & & 132 & 1 & 0.241 & & & & & & & & \\
\hline & & & & & 42 & 5 & 0.125 & & all & 32 & 321 & 12 & 311 & 57 & 0.477 \\
\hline & & & & & & & & & & & & & 140 & 32 & 0.340 \\
\hline & all & 79 & 173 & 59 & 205 & 75 & 0.525 & & & & & & 48 & 4 & 0.173 \\
\hline & & & & & 332 & 9 & 0.263 & & & & & & & & \\
\hline & & & & & 64 & 12 & 0.211 & W-5 & 1 & 9 & 225.5 & 30 & 221 & 38 & 0.622 \\
\hline & & & & & & & & & & & & & 101 & 33 & 0.299 \\
\hline \multirow[t]{15}{*}{ TBR-3 } & 1 & 24 & 191 & 28 & 203 & 76 & 0.550 & & & & & & 344 & 35 & 0.001 \\
\hline & & & & & 2 & 13 & 0.239 & & & & & & & & \\
\hline & & & & & 347 & 58 & 0.211 & & 2 & 25 & 324 & 58 & 347 & 29 & 0.520 \\
\hline & & & & & & & & & & & & & 195 & 58 & 0.348 \\
\hline & 2 & 62 & 199 & 75 & 203 & 76 & 0.713 & & & & & & 84 & 13 & 0.138 \\
\hline & & & & & 2 & 13 & 0.159 & & & & & & & & \\
\hline & & & & & 93 & 50 & 0.127 & & 3 & 15 & 186 & 68 & 181 & 68 & 0.583 \\
\hline & & & & & & & & & & & & & 30 & 20 & 0.244 \\
\hline & 3 & 29 & 193 & 51 & 193 & 51 & 0.640 & & & & & & 297 & 10 & 0.172 \\
\hline & & & & & 312 & 27 & 0.221 & & & & & & & & \\
\hline & & & & & 56 & 31 & 0.138 & & all & 49 & 192 & 30 & 200 & 59 & 0.450 \\
\hline & & & & & & & & & & & & & 354 & 29 & 0.350 \\
\hline & all & 115 & 194 & 61 & 192 & 65 & 0.618 & & & & & & 90 & 11 & 0.195 \\
\hline & & & & & 342 & 22 & 0.221 & & & & & & & & \\
\hline & & & & & 77 & 11 & 0.001 & & & & & & & & \\
\hline
\end{tabular}


similar to the results in TBR-1 and TBR-3. Although the strike of this second set may coincide with the high-altitude lineament that could project through $\mathrm{W}-5$, the dip is shallow and to the west. This dip is not consistent with the interpretation of east dipping features striking in the same direction in TBR-1 and TBR-3.

The hydraulically active fractures that were identified in the standard logs of wells TBR-1, TBR-2, and TBR-3 strike in all directions from $\mathrm{N} 12^{\circ}$ to $\mathrm{N} 349^{\circ} \mathrm{E}$ and dip from 3 to $80^{\circ}$ in all directions. There were 32 features included in the eigenvector analyses. The results of the eigenvector analyses for all of the hydraulically active fractures from these wells indicate a dominant fracture set with an eigenvalue of 0.551 and an orientation of $\mathrm{N} 167^{\circ} \mathrm{E}$, dipping $30^{\circ}(\mathrm{W})$ and a secondary set with an orientation of $\mathrm{N} 9^{\circ} \mathrm{E}$, dipping $58^{\circ}(\mathrm{E})$. In general, the dominant fracture set coincides with the strike of nearby photolinear features to the west of the wells (fig. 1). The strike and dip of individual fractures can be obtained from table 1 .

Correlating the water-bearing zones that were identified at the time of drilling with individual fractures in the ATV logs was difficult. In TBR-3, the zone from 205 to $210 \mathrm{ft}$ was reported to have a yield of about $100 \mathrm{gal} / \mathrm{min}$ (Gary Smith, D.L. Maher, written commun., 1996). This discrete zone was intersected by six fractures (table 1) striking $\mathrm{N} 40^{\circ} \mathrm{E}, \mathrm{N} 183^{\circ} \mathrm{E}$, and $\mathrm{N} 352^{\circ} \mathrm{E}$ and dipping $\mathrm{SE}, \mathrm{W}$, and NE. Because of the variation in orientation of fractures, it is not possible to correlate these well-drillers' yields with individual fracture orientations.

In conclusion, the ATV logs and results of the eigenvector analyses indicate that the wells in the two well fields are highly fractured. In addition, there are statistically significant fracture sets that coincide with the remotely-sensed lineaments that are mapped in the two well fields (fig 1). Although the mean vector for the entire distribution coincides with some of the dominant eigenvectors, eigenvector analysis helped identify multiple fracture sets in the widely scattered data. The eigenvectors that were computed coincide with several of the lineaments identified by fracturetrace analysis. The correlation of fracture sets identified in wells and lineaments might not have been evident through mean vector analysis alone.

\section{Radar-Reflection Logs}

The average velocity of the radar waves at the site was approximately $88 \mathrm{~m} / \mu \mathrm{s}$. An unprocessed radar record, from TBR-2, which is also called a radargram (fig. 19), shows the direct-arrival radar amplitude plotted as a function of depth. The x-axis represents the two-way travel time in nanoseconds, as well as the radial distance from the well, in meters. Depth of the borehole is plotted on the $y$-axis in meters. In the radargram of TBR-2, the low-velocity zones were identified at center depths of 30 to 50, 170, and $240 \mathrm{ft}$. In addition, minor low-velocity zones are present at center depths of 301 and $344 \mathrm{ft}$. Each of these zones coincides with enlarged zones on the caliper log, deflections in the fluid logs, and (or) fractures identified in ATV and video interpretations (fig. 4). The low velocities at 240 and $344 \mathrm{ft}$ were also

TWO-WAY RADAR TRAVEL TIME, IN MICROSECONDS

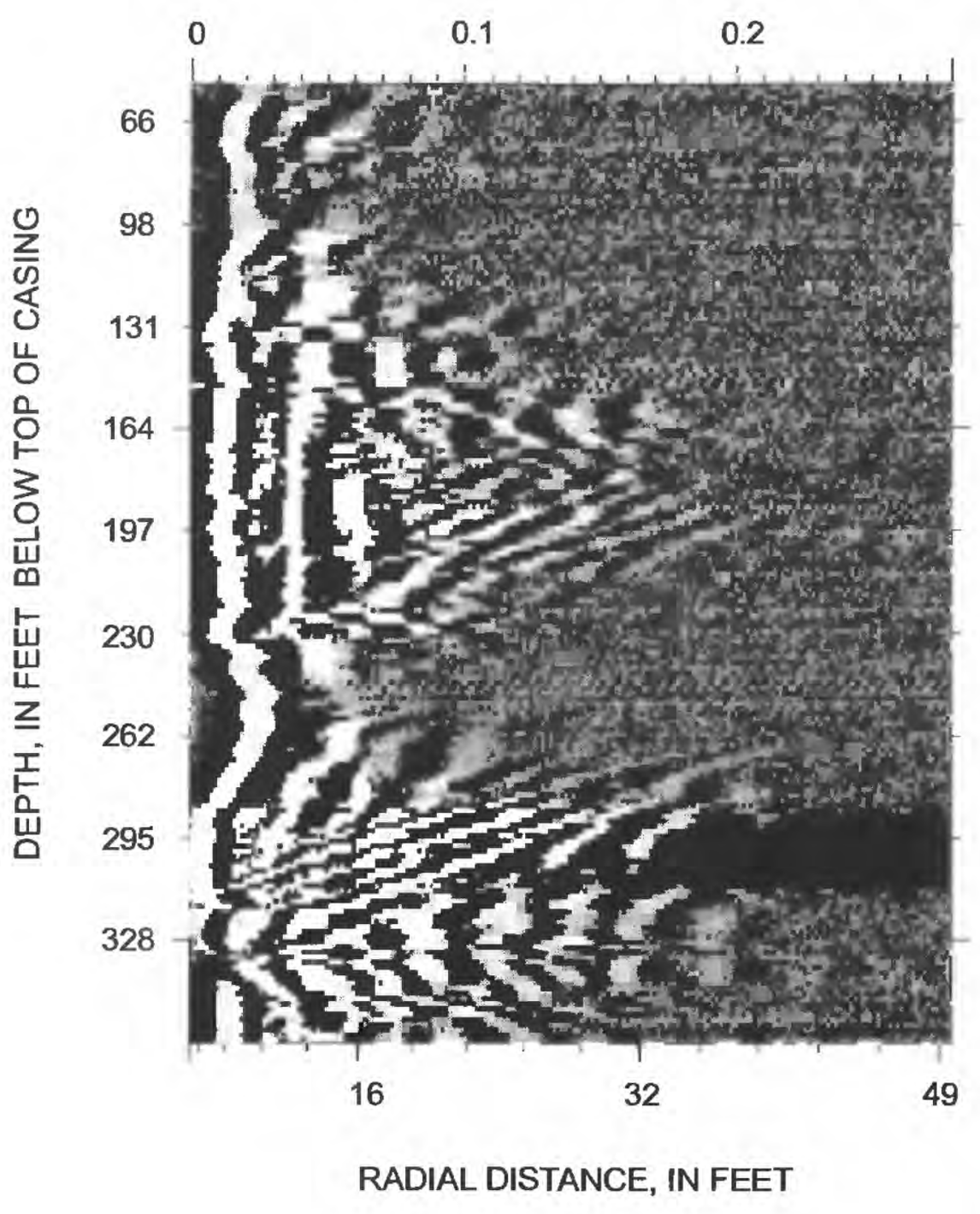

Figure 19. Unprocessed borehole-radar log of well TBR-3 in Rye, New Hampshire. 
accompanied by high-attenuation signatures, which represent zones of minimal penetration of the radar signal. Radar responses that exhibit low velocity and high attenuation are indicative of saturated fractures that are potential-water-bearing zones (Chapman and Lane, 1996). Electromagnetic radiation penetration at the site extended approximately $50 \mathrm{ft}$ from the well. In general, it was less than $30 \mathrm{ft}$. The low-signal propagation is probably caused by attenuation due to the highly fractured nature of this bedrock. The combination of many reflectors and high attenuation is indicative of a highly fractured water-bearing aquifer.

Interpreting the orientation of many of the individual radar reflectors was difficult. The trace of the reflector, which provided the location and the dip of the reflector, could be determined, however, because of the noise in the attenuation record, the strike could not always be resolved. Where the strike could be resolved, the accuracy of an interpreted strike of a reflector is about \pm 10 degrees. Midpoint depth (center depth between the high and low point of a dipping fracture), strike, and dip of the major planar reflectors interpreted in the bedrock surrounding the well are listed in table 3. The reflectors are projected to the borehole to determine the depth of intersection, but a reflector may not necessarily intersect the borehole wall. A negative depth of intersection indicates a reflector that is projected to intersect the well above the land surface or above the top of casing. A feature that has a depth of intersection that is below the bottom of the well is a reflector that was identified at some distance from the well and dips towards the well but does not intersect the well.

Table 3. Projected midpoint depth, strike and dip of reflectors identified by borehole radar for wells TBR-2, TBR-3, and W5, in Rye, New Hampshire

[Negative depths indicate a projected plane intersects above the well; -- indicates the strike cannot be determined. The strike is reported in RHR, "right-hand rule" where the direction of dip is to the right of the strike]

\begin{tabular}{|c|c|c|c|c|c|c|c|c|c|}
\hline $\begin{array}{l}\text { Depth } \\
\text { (feet) }\end{array}$ & $\begin{array}{c}\text { Depth } \\
\text { (meters) }\end{array}$ & $\begin{array}{c}\text { Strike } \\
\text { (degrees) }\end{array}$ & $\begin{array}{c}\text { Dip } \\
\text { (degrees) }\end{array}$ & Comments & $\begin{array}{l}\text { Depth } \\
\text { (feet) }\end{array}$ & $\begin{array}{c}\text { Depth } \\
\text { (meters) }\end{array}$ & $\begin{array}{c}\text { Strike } \\
\text { (degrees) }\end{array}$ & $\begin{array}{c}\text { Dip } \\
\text { (degrees) }\end{array}$ & Comments \\
\hline \multicolumn{5}{|c|}{ Reflectors from well TBR-2 } & \multicolumn{5}{|c|}{ Reflectors from well TBR-3-Continued } \\
\hline-551.9 & -168.2 & 44 & 87 & & -198.8 & -60.6 & 214 & 83 & \\
\hline-16.7 & -5.1 & 254 & 81 & Low confidence strike & 18.0 & 5.5 & 74 & 86 & \\
\hline-9.2 & -2.8 & 64 & 79 & & 24.0 & 7.3 & 114 & 80 & \\
\hline 35.4 & 10.8 & -- & 71 & & 35.1 & 10.7 & 304 & 82 & \\
\hline 122.4 & 37.3 & - & 80 & & 79.7 & 24.3 & 214 & 80 & \\
\hline 129.3 & 39.4 & -- & 75 & & 93.8 & 28.6 & 304 & 68 & \\
\hline 136.8 & 41.7 & 264 & 83 & & 140.1 & 42.7 & 344 & 77 & \\
\hline 139.1 & 42.4 & 54 & 55 & & 159.5 & 48.6 & 24 & 53 & \\
\hline 156.8 & 47.8 & -- & 72 & & 203.8 & 62.1 & 204 & 61 & \\
\hline 161.8 & 49.3 & 144 & 77 & & 210.6 & 64.2 & 14 & 75 & \\
\hline 169.3 & 51.6 & 4 & 83 & & 216.2 & 65.9 & 34 & 59 & \\
\hline 177.5 & 54.1 & 134 & 58 & Low confidence strike & 251.0 & 76.5 & 234 & 56 & \\
\hline 195.9 & 59.7 & 184 & 66 & & 312.4 & 95.2 & 44 & 51 & \\
\hline 240.2 & 73.2 & 234 & 44 & & 423.9 & 129.2 & -- & 85 & \\
\hline 252.6 & 77 & 254 & 64 & Low confidence strike & 552.2 & 168.3 & 294 & 84 & \\
\hline 284.5 & 86.7 & -- & 66 & & \multicolumn{5}{|c|}{ Reflectors from well W5 } \\
\hline 288.7 & 88 & 314 & 49 & & -37.7 & -11.5 & - & 85.3 & Faint feature \\
\hline 329.1 & 100.3 & 244 & 58 & Low confidence strike & 18.0 & 5.5 & 194 & 82.2 & \\
\hline 331.1 & 100.9 & 244 & 75 & & 102.0 & 31.1 & 14 & 84.2 & \\
\hline 344.5 & 105 & 294 & 46 & & 167.3 & 51 & 344 & 70.3 & \\
\hline 397.0 & 121 & & 59 & & 229.7 & 70 & 354 & 58.7 & Low velocity \\
\hline 404.9 & 123.4 & & 51 & & 270.0 & 82.3 & 294 & 59.3 & \\
\hline \multicolumn{5}{|c|}{ Reflectors from well TBR-3 } & 304.1 & 92.7 & 334 & 78.2 & Low velocity \\
\hline-645.4 & -196.7 & 24 & 88 & & 412.4 & 125.7 & -- & 48.3 & \\
\hline-571.6 & -174.2 & 114 & 86 & & 418.0 & 127.4 & - & 67.8 & \\
\hline-394.4 & -120.2 & - & 88 & & 458.7 & 139.8 & 214 & 81.5 & \\
\hline-387.5 & -118.1 & 294 & 82 & & & & & & \\
\hline
\end{tabular}


Many reflectors were observed in the directional radar logs of well TBR-3 (fig. 19). This unprocessed radar record, or radargram, from well TBR-3 indicates low velocity zones are at $20,50,215$ to 260 , and $340 \mathrm{ft}$. Reflectors with low velocity and high attenuation at center depths of 49 and $246 \mathrm{ft}$ are interpreted as water-saturated fractures or fracture zones. These depths are close to major fractures that were identified in the standard logs.

The unprocessed radar record from well W-5 (fig. 20) indicates low-velocity zones at 245, 300, and $395 \mathrm{ft}$ and high attenuation at 245 and $395 \mathrm{ft}$. These low-velocity and high-attenuation zones appear to correlate with major fracture intersections with the borehole and with the deflections in the fluid resistivity and temperature logs (fig. 9). The fracture at $395 \mathrm{ft}$ is shown in figure 9. The individual radar traces are noted in table 3 . In the highly attenuated zones, the strike of the reflector could not be determined because of high attenuation or because the strong reflectors produced apparent radar signals from all directions.

The radar surveys show the rock surrounding TBR-2 and TBR-3 is intensely fractured. In general, high-attenuation and low-velocity zones in the radargrams correlate with fractures and fracture zones observed in the standard and ATV logs. Many radar reflectors were identified in the aquifer surrounding the two wells. The reflectors identified in the radar surveys were steeply dipping and plot towards the outside of a stereogram. Interpreted orientations of reflectors of wells TBR- 2 and TBR- 3 are shown as a

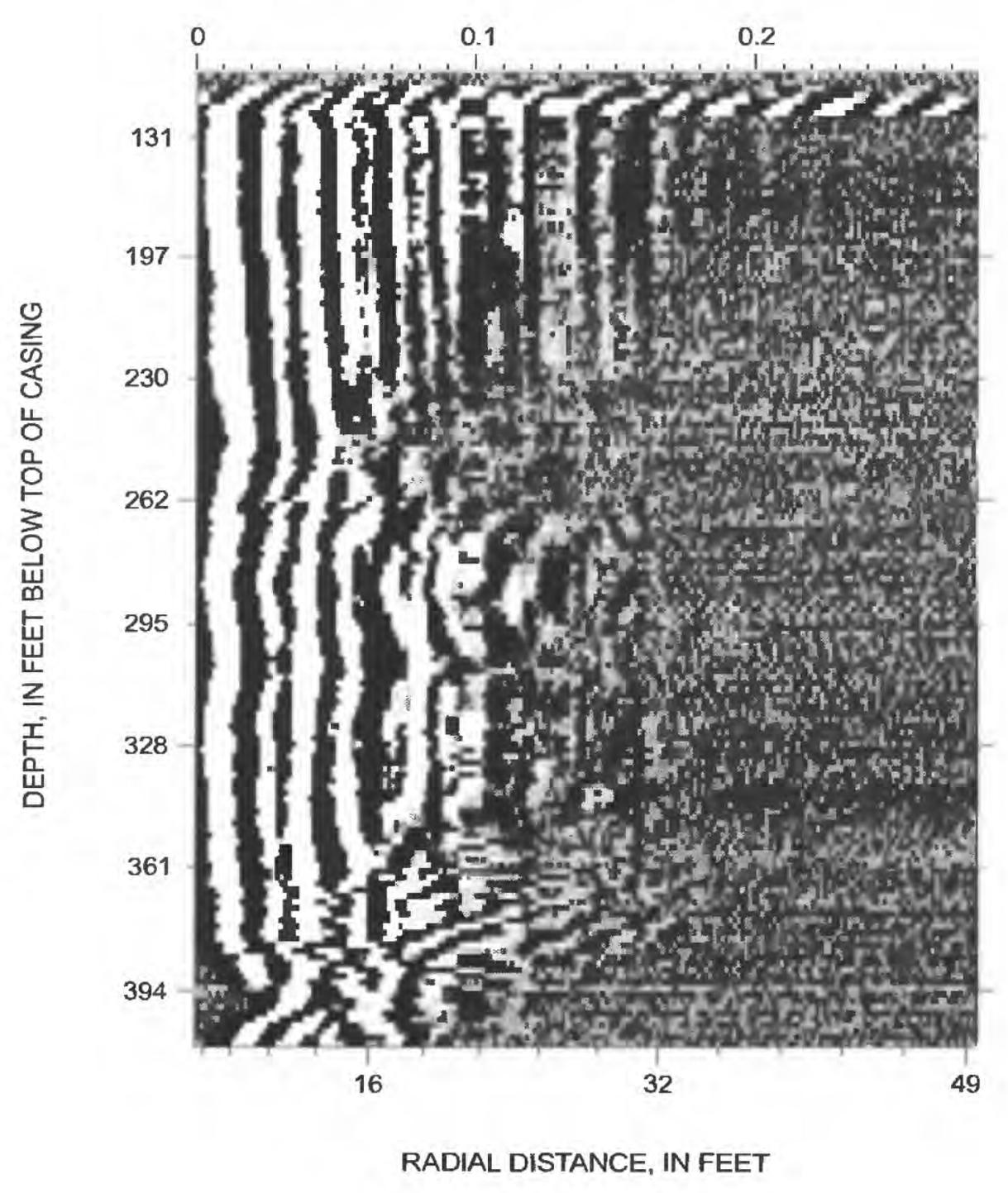

Figure 20. Unprocessed borehole radar log of well W-5 in Rye, New Hampshire. 


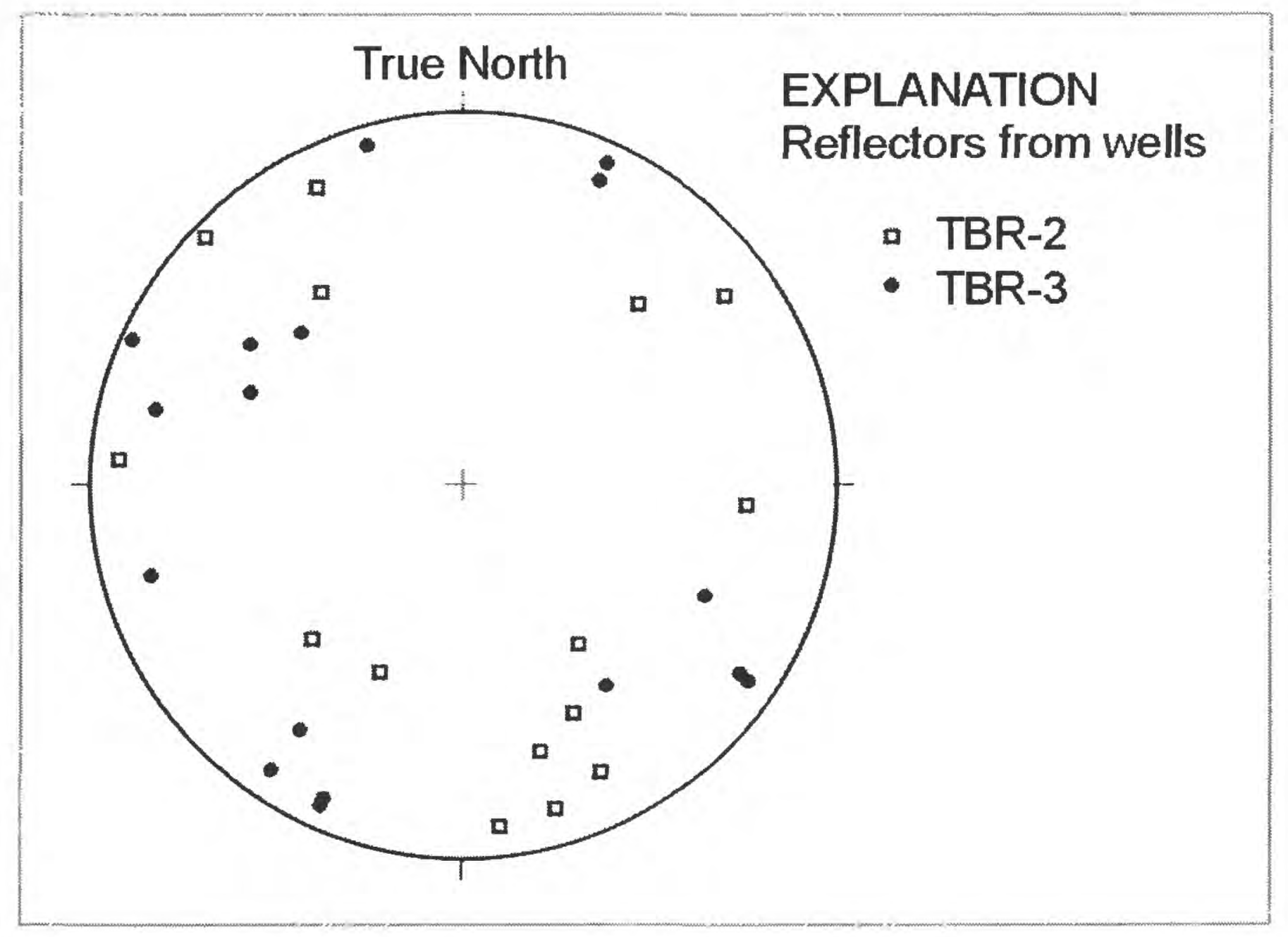

Figure 21. Stereogram of radar reflectors from wells TBR-2 and TBR-3 in Rye, New Hampshire.

stereogram in figure 21. A comparison of individual reflectors with fractures in the ATV logs (appendix 1) is difficult, as there is more variation in the fractures shown in the ATV logs. This difference is inherent in the two methods because different scales of observation are used. Borehole radar is primarily influenced by large-scale features, which can be several feet from the borehole, whereas the ATV log identifies relatively small-scale features that intersect the borehole. Aquifers that are intensely fractured, such as in the Cedar Run well field, produce different fracture patterns when different detection methods are used.

\section{SUMMARY AND CONCLUSIONS}

Six wells were investigated in Rye, New Hampshire, to characterize a high-yield bedrock aquifer and to demonstrate how advanced geophysical techniques are applied and interpreted. The wells, which penetrate schists and gneiss of the Rye Complex, intersect a number of fractures. Borehole geophysical logs were collected to identify and determine orientation of the fractures and the waterbearing zones. Several of the wells had vertical flow between fractures under non-pumping, natural conditions. In well TBR-3, the vertical flow was measured by use of a heat-pulse flowmeter log. Under ambient conditions, flow was as much as $0.37 \mathrm{gal} / \mathrm{min}$ in the borehole.

The geophysical logs indicate that the bedrock aquifer is highly fractured with various fracture orientations. Statistical analyses of the orientations indicate that several fracture sets intersect the wells. The strikes of these fracture sets were found to be parallel to the trend of several of the lineaments that were identified on high- and low-aerial photography and SLAR platforms of the study area. The strike of the fracture sets and the trend of the lineaments were coincident at approximately $\mathrm{N} 40^{\circ} \mathrm{E}, \mathrm{N} 100^{\circ} \mathrm{E}, \mathrm{N} 140^{\circ} \mathrm{E}$, and $\mathrm{N} 170^{\circ} \mathrm{E}$. A prominent fracture set was identified in wells TBR-1, TBR-2, TBR-3, and W-5 that strikes $\mathrm{N} 171^{\circ}$ to $\mathrm{N} 203^{\circ} \mathrm{E}$ and dips $32^{\circ}$ to $70^{\circ} \mathrm{W}$. Another set was identified in wells TBR- 2 and W- 3 that strikes $\mathrm{N} 307^{\circ}$ to $\mathrm{N} 320^{\circ} \mathrm{E}$ and has a steep $\operatorname{dip}\left(49^{\circ}\right.$ to $\left.74^{\circ}\right)$ to 
the northeast. These two sets also were identified by Brooks (1986).

Borehole-radar logs identified several reflectors in the aquifer surrounding three of the wells. The radargrams for these wells show zones of low velocity and high attenuation that coincide with fractures in the wells. The electromagnetic radiation had limited penetration (generally less than $30 \mathrm{ft}$ ) into the surrounding aquifer because the signal was attenuated in the intensely fractured aquifer. Fractured zones with low velocity and high attenuation are frequently indicative of water-bearing zones.

\section{SELECTED REFERENCES}

Brooks, J.A., 1986, Geology of New Hampshire's inner continental shelf: University of New Hampshire, Durham, N.H., published Master's thesis, 109 p.

Brooks, J.A., and Rickerich, S., 1996, A field excursion to the coastal region of New Hampshire and the Isles of Shoals, 1996: Portsmouth, N.H., New Hampshire Geological Society, annual field outing, Guidebook to summer field trip and outing, $8 \mathrm{p}$.

Chapman, M.J., and Lane, J.W., Jr., 1996, Use of directional borehole radar and azimuthal square-array D.C. resistivity methods to characterize a crystallinebedrock aquifer, in Symposium on the Application of Geophysics to Engineering and Environmental Problems, April 28-May 2, 1996: Keystone, Colo., p. 833-842.

Clark, S.F., Jr., Moore, R.B., Ferguson, E.W., and Picard, M.Z., 1996, Criteria and methods for fracture trace analysis of New Hampshire bedrock aquifer: U.S. Geological Survey Open-File Report 96-479, 12 p.

D.L. Maher Co., 1982, The evaluation of alternative groundwater supplies, Town of Rye, New Hampshire: North Reading, Mass., 20 p.

Ferguson, E.W., Clark, S.F., Jr., Moore, R.B., 1997, Lineament map of area 1, of the New Hampshire bedrock aquifer assessment, southeastern New Hampshire: U.S. Geological Survey Open-File Report 96-489, 1 pl., scale 1:48,000.

Hess, A.E., and Paillet, F.L., 1990, Applications of the thermal-pulse flowmeter in the hydraulic characterization of fractured rocks: American Society for Testing and Materials, Standard Technical Publications 1101, p. 99-112.

Hussey, A.M., and Bothner, W.A., 1993, Geology of the coastal lithotechtonic belt SW Maine and SE New Hampshire, in 1993 Geological Society of America annual meeting and $85^{\text {th }}$ annual New England Intercollegiate Geological Conference, Boston, Mass., Oct. 25-
28, 1993, Field trip guidebook for the northeastern United States: Geological Society of America, $20 \mathrm{p}$.

Johnson, C.D., 1996, Use of a borehole color video camera to identify lithologies, fractures, and borehole conditions in bedrock wells in the Mirror Lake area, Grafton County, New Hampshire, in Morganwalp, D.W., and Aronson, D.A., eds., U.S. Geological Survey Toxic Substance Hydrology-Proceedings of Technical Meeting, Colorado Springs, Colo., September 20-24, 1993: U.S. Geological Survey Water-Resources Investigations Report 94-4015, v. 1, p. 89-94.

Johnson, C.D., and Dunstan, A.H., 1998, Lithology and fracture characterization from drilling investigations in the Mirror Lake area, Grafton County, New Hampshire: U.S. Geological Survey Water-Resources Investigations Report 98-4183, 216 p.

Keyes, W.S., 1988, Borehole geophysics applied to groundwater investigations: U.S. Geological Survey OpenFile Report 87-539, 305 p.

Lane, J.W., Jr., Haeni, F.P., and Williams, J.H., 1994,

Detection of bedrock fractures and lithologic changes using borehole radar at selected sites, in Fifth International Conference on Ground-Penetrating Radar, Kitchner, Ontario, Canada, June 12-16, 1993, Proceedings: Kitchner, Ontario, Waterloo Center for Groundwater Research, p. 577-591.

Lyons, J.B., Bothner, W.A., Moench, R.H., and Thompson, J.B., Jr., 1997, Bedrock geologic map of New Hampshire: U.S. Geological Survey State Geologic Map, 2 sheets, scale 1:250,000 and 1:500,000.

Moore, R.B., and Clark, S.F., 1995, Assessment of groundwater supply potential of bedrock in New Hampshire: U.S. Geological Survey Fact Sheet FS 95-002, 2 p.

Novotny, R.F., 1969, The geology of the seacoast region New Hampshire: Concord, N.H., New Hampshire Department of Resources and Economic Development, 46 p., 1 pl., scale 1:62,5000.

Paillet, F.L., and Pedler, W.H., 1996, Integrated borehole logging methods for wellhead protection applications: Engineering Geology, v. 42, p. 155-165.

Paillet, F.L., and Williams, J.H., 1992, Proceedings of the U.S. Geological Survey workshop on the application of borehole geophysics to ground-water investigations, Albany, New York: U.S. Geological Survey OpenFile Report 94-4103, 79 p.

Woodcock, N.H., 1977, Specification of fabric shapes using an eigenvalue method: Geological Society of America Bulletin, v. 88, p. 1231-1236. 
APPENDIX 
Acoustic Televiewer Logs of Wells:

W-3

W-4

W-5

TBR-1 51

TBR-2 54

TBR-3 
APPENDIX 1. ACOUSTIC TELEVIEWER LOG OF WELL W-3, RYE, NEW HAMPSHIRE

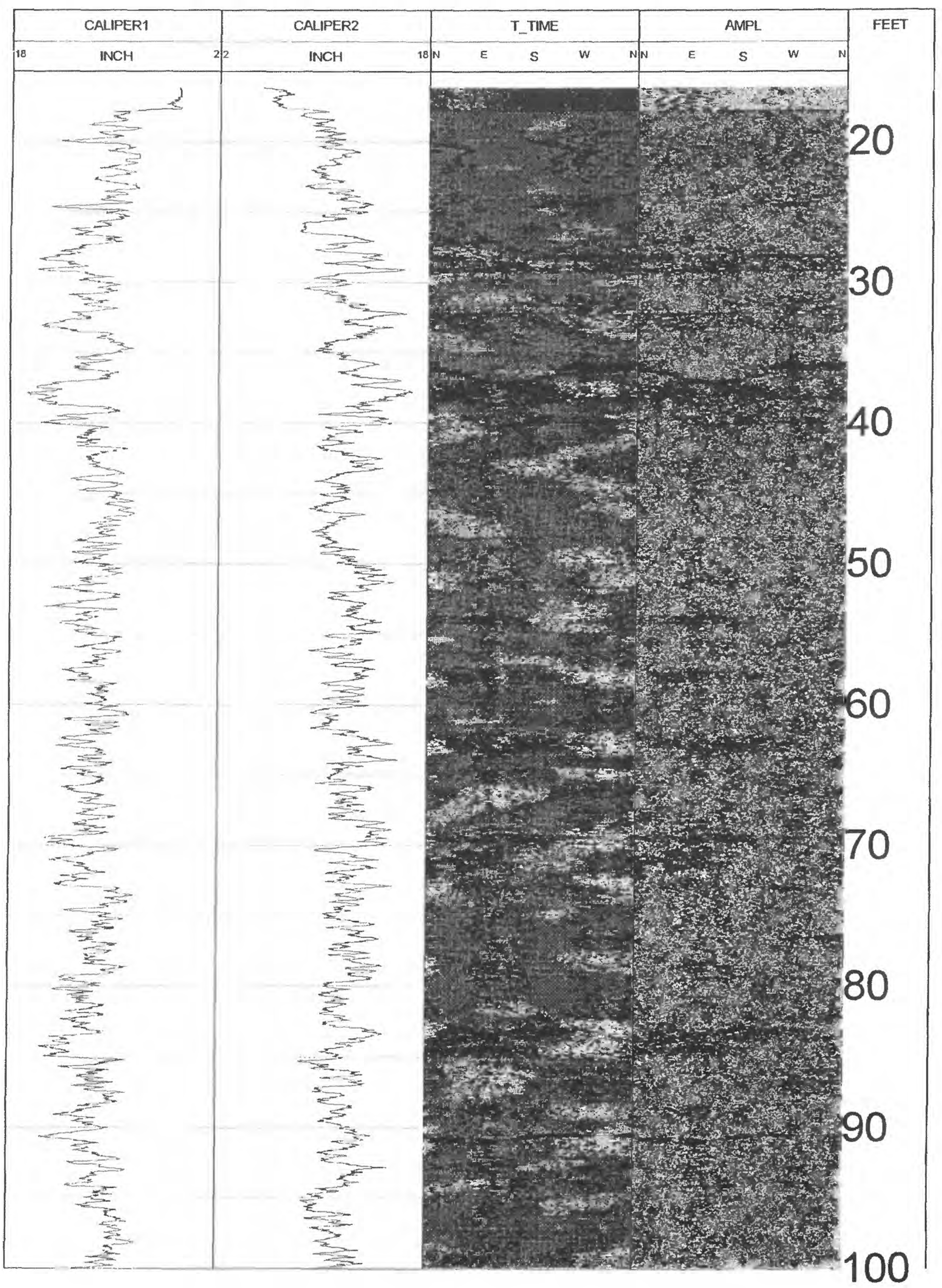


APPENDIX 1. ACOUSTIC TELEVIEWER LOG OF WELL W-3, RYE, NEW HAMPSHIRE--Continued

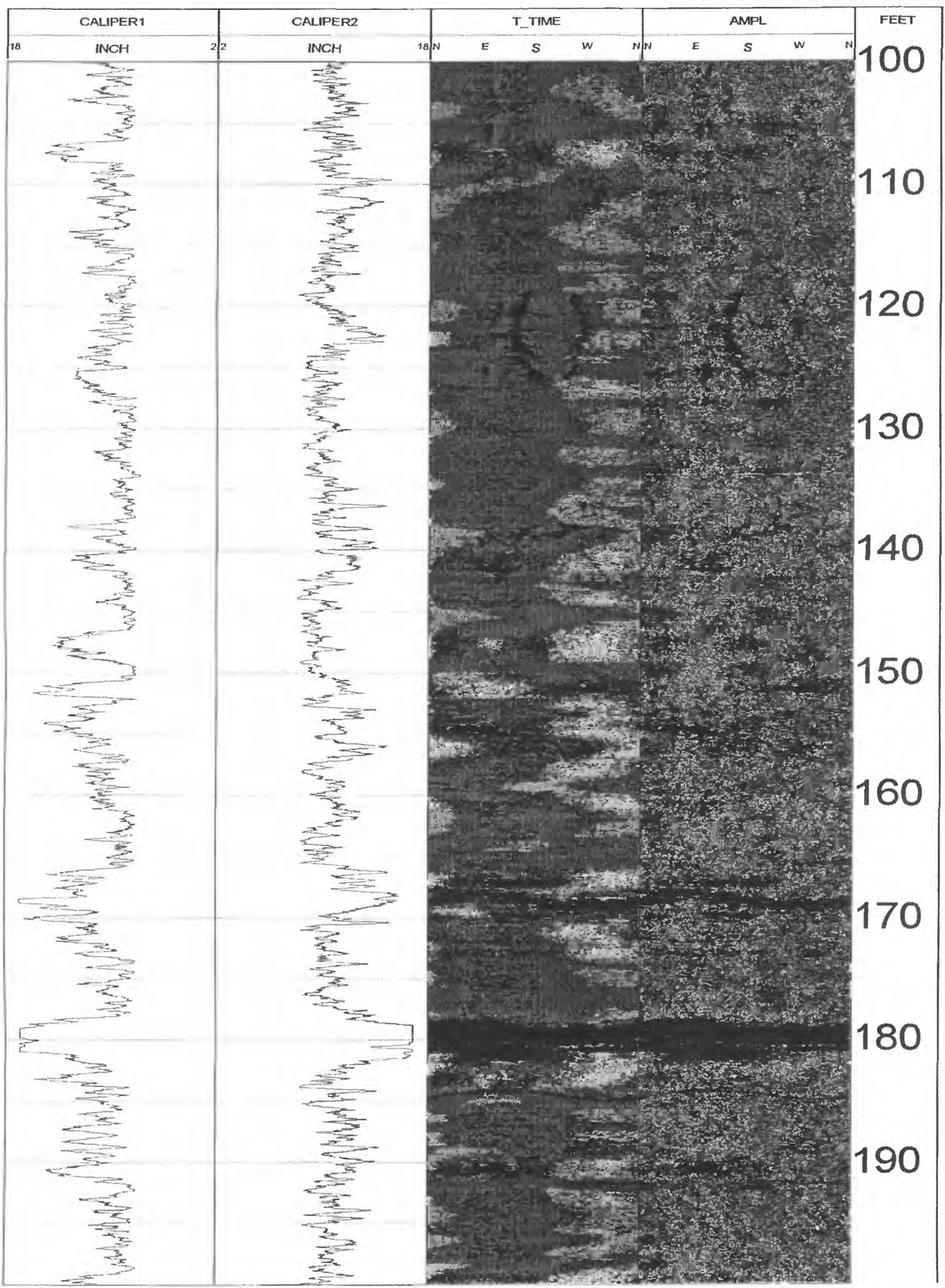


APPENDIX 1. ACOUSTIC TELEVIEWER LOG OF WELL W-3, RYE, NEW HAMPSHIRE--Continued

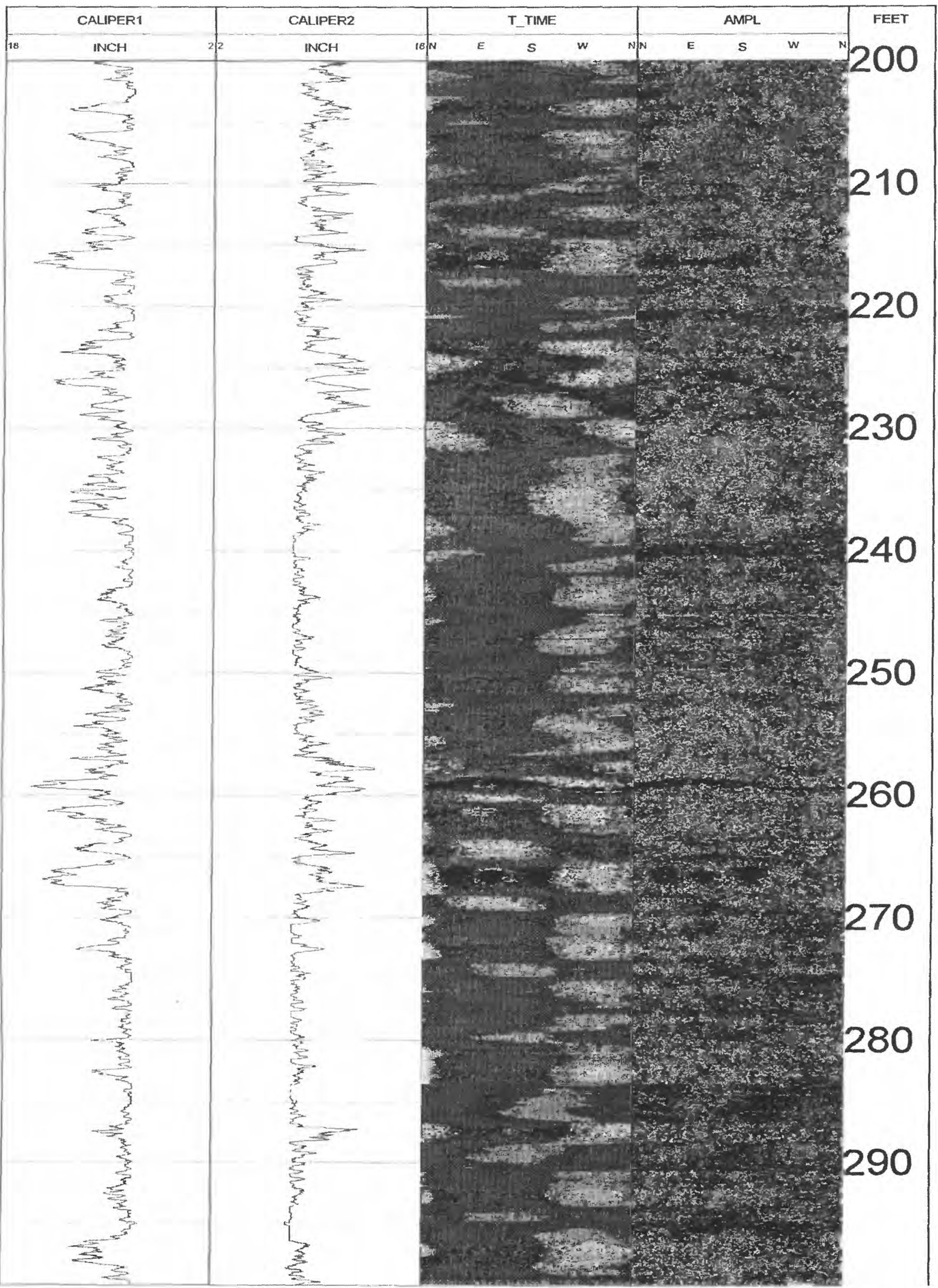


APPENDIX 1. ACOUSTIC TELEVIEWER LOG OF WELL W-3, RYE, NEW HAMPSHIRE--Continued

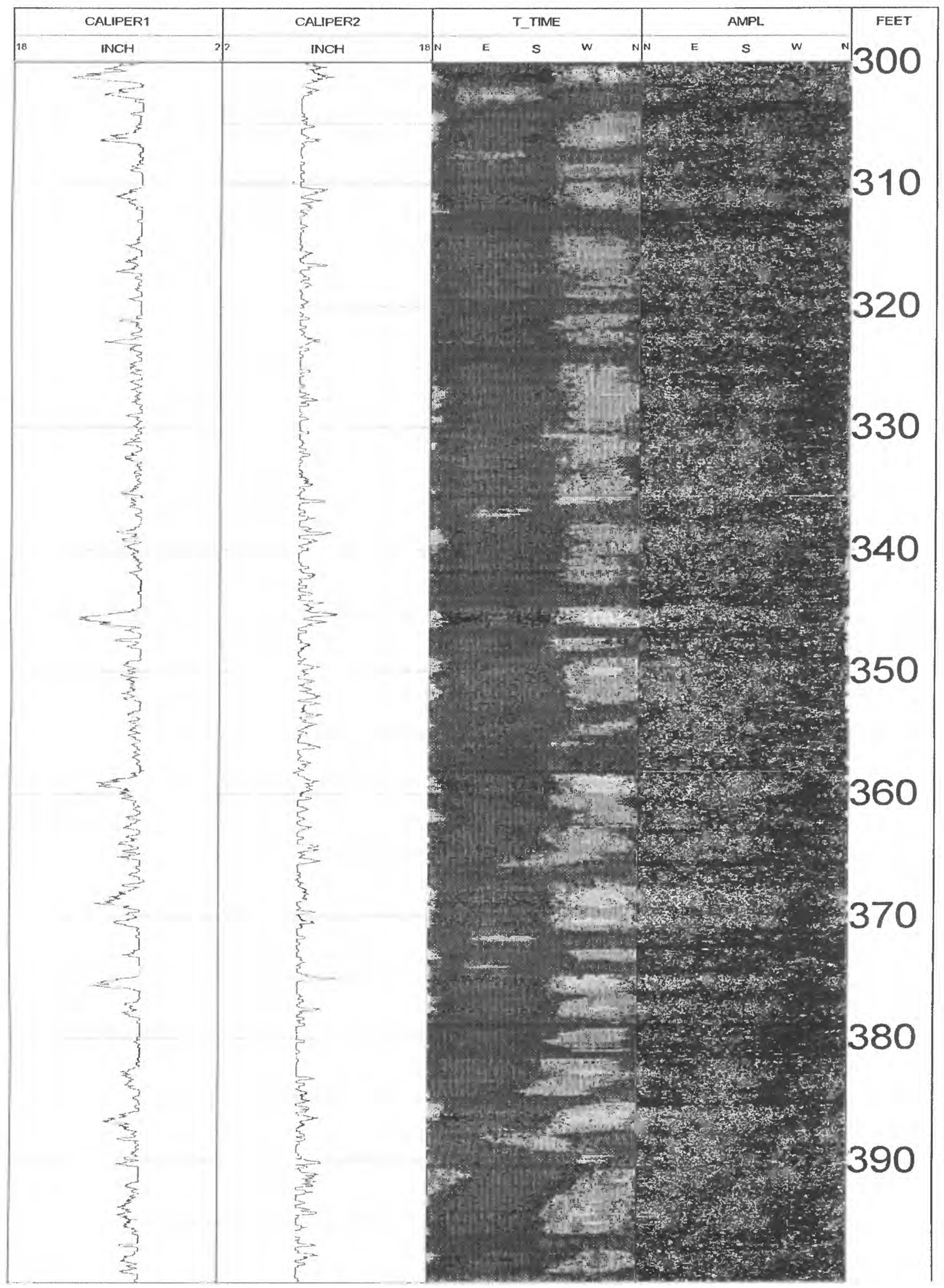


APPENDIX 1. ACOUSTIC TELEVIEWER LOG OF WELL W-3, RYE, NEW HAMPSHIRE--Continued

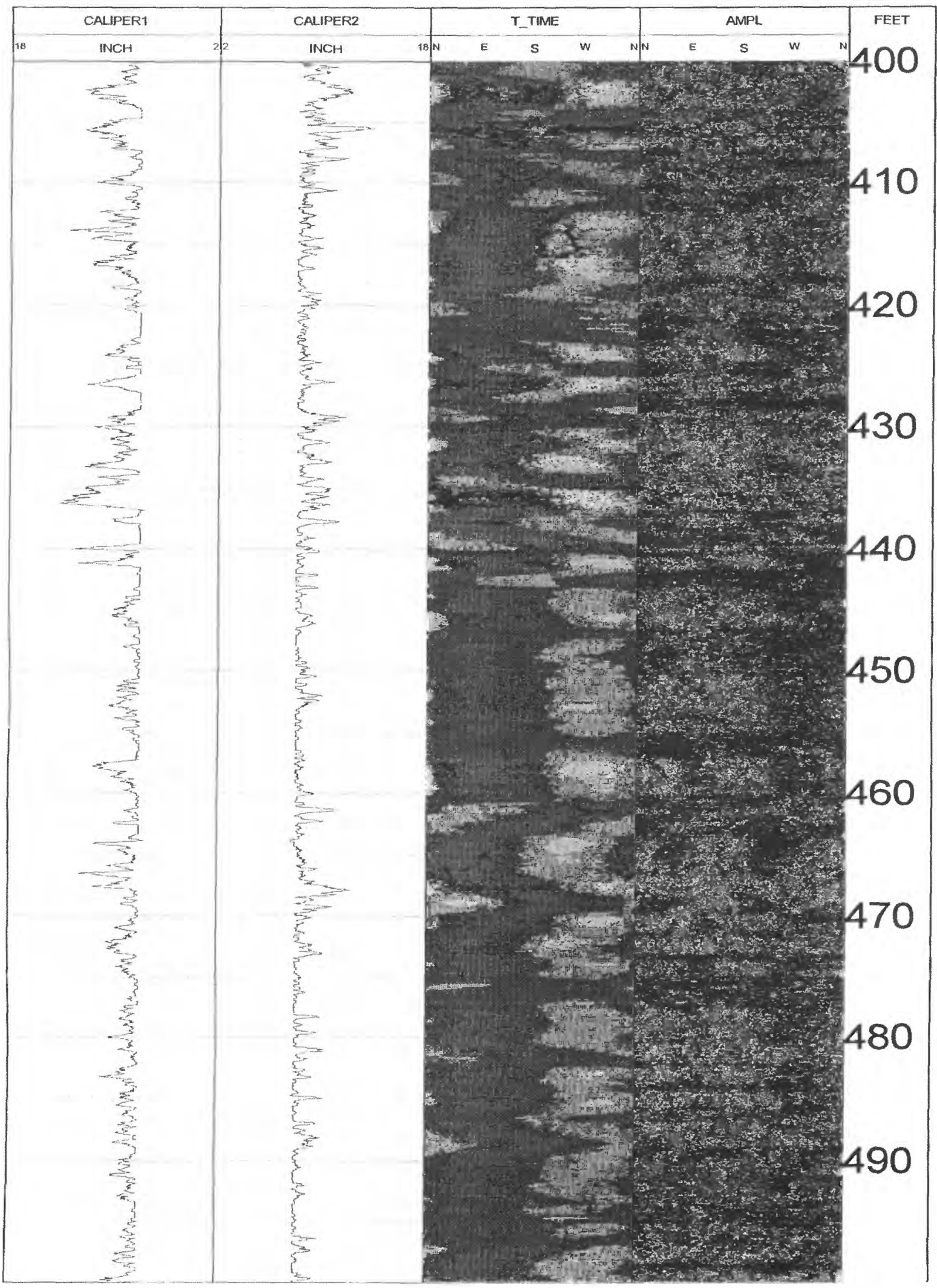


APPENDIX 1. ACOUSTIC TELEVIEWER LOG OF WELL W-3, RYE, NEW HAMPSHIRE--Continued

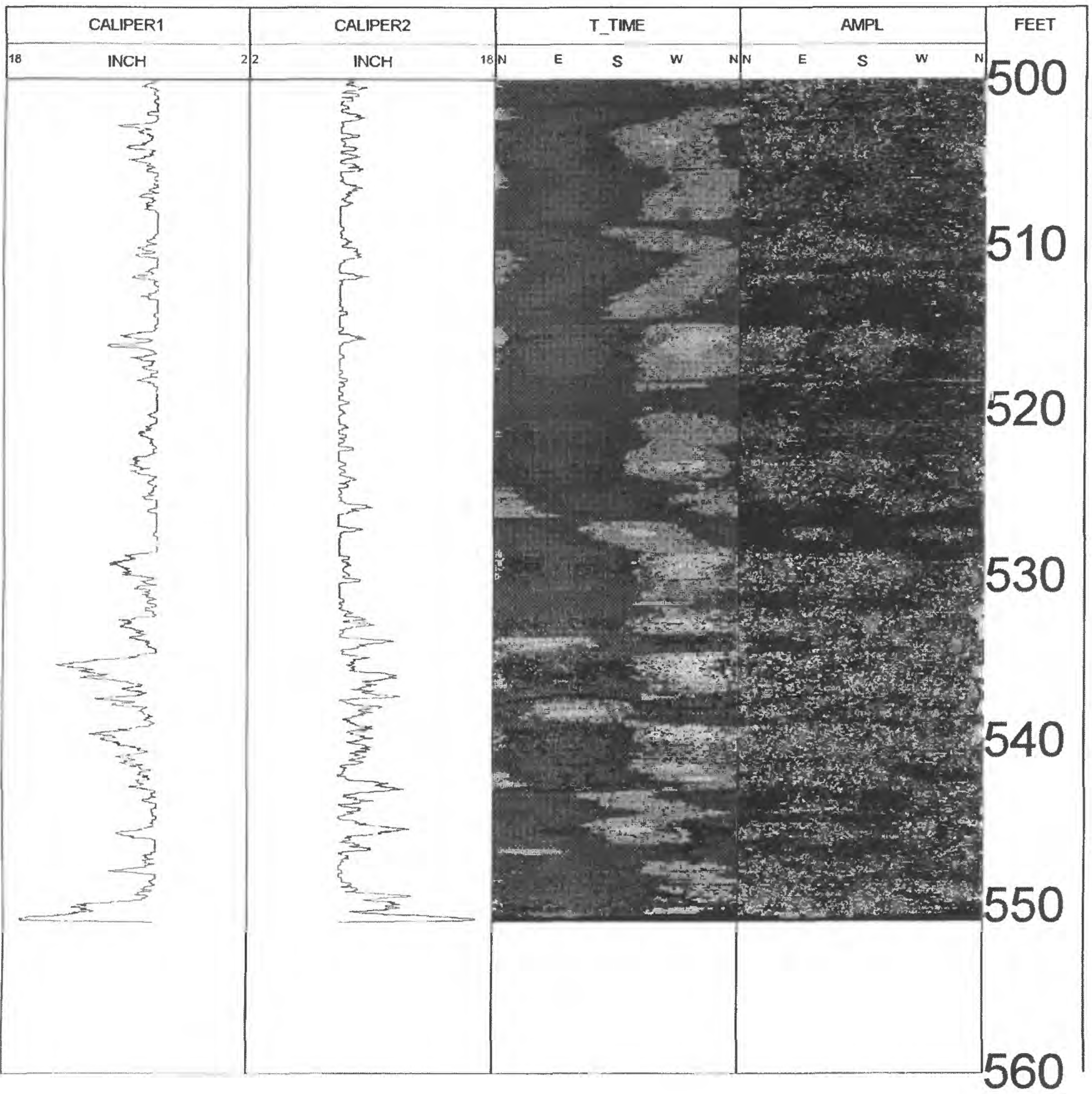


APPENDIX 1. ACOUSTIC TELEVIEWER LOG OF WELL W-4, RYE, NEW HAMPSHIRE

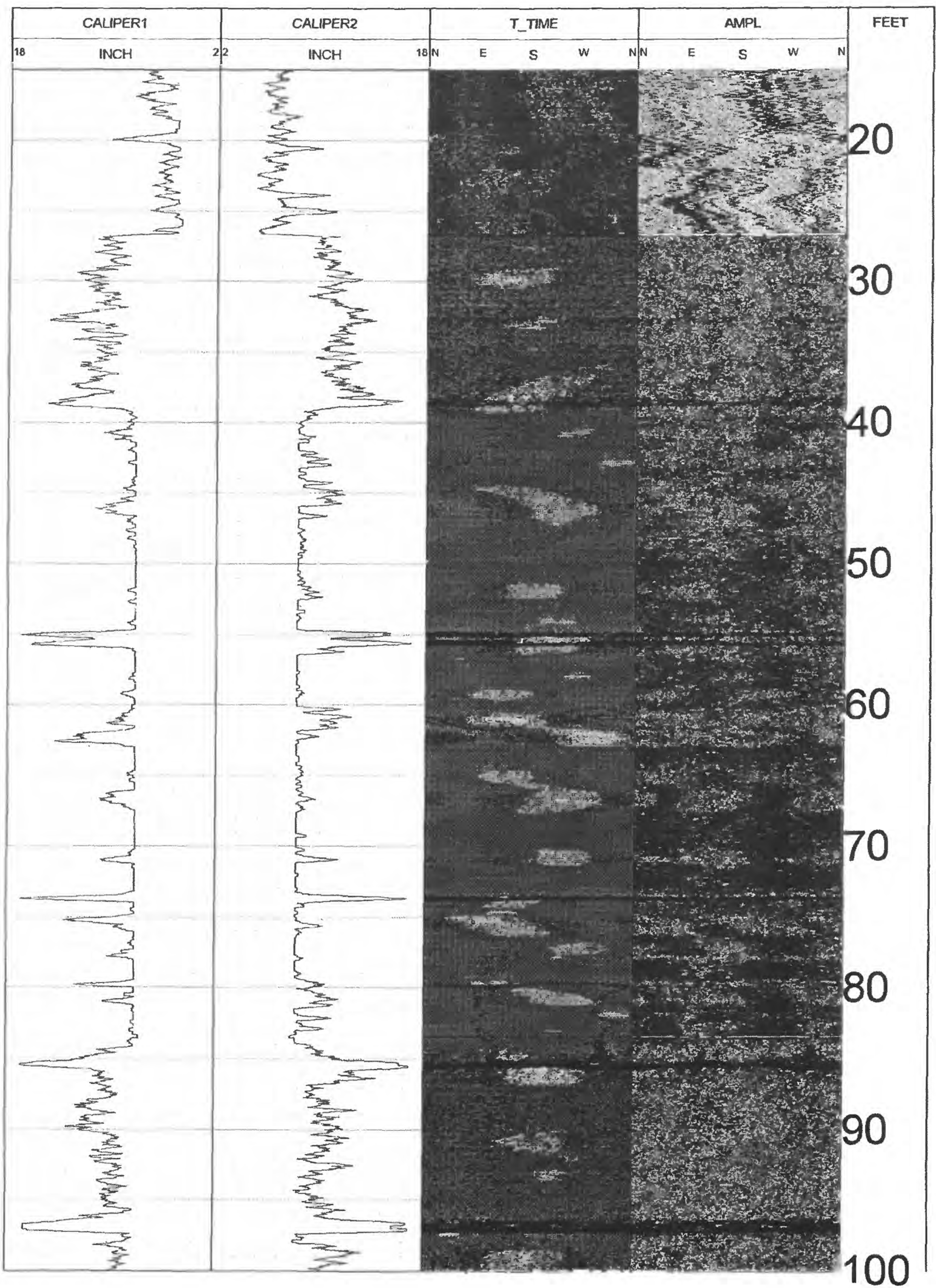


APPENDIX 1. ACOUSTIC TELEVIEWER LOG OF WELL W-4, RYE, NEW HAMPSHIRE--Continued

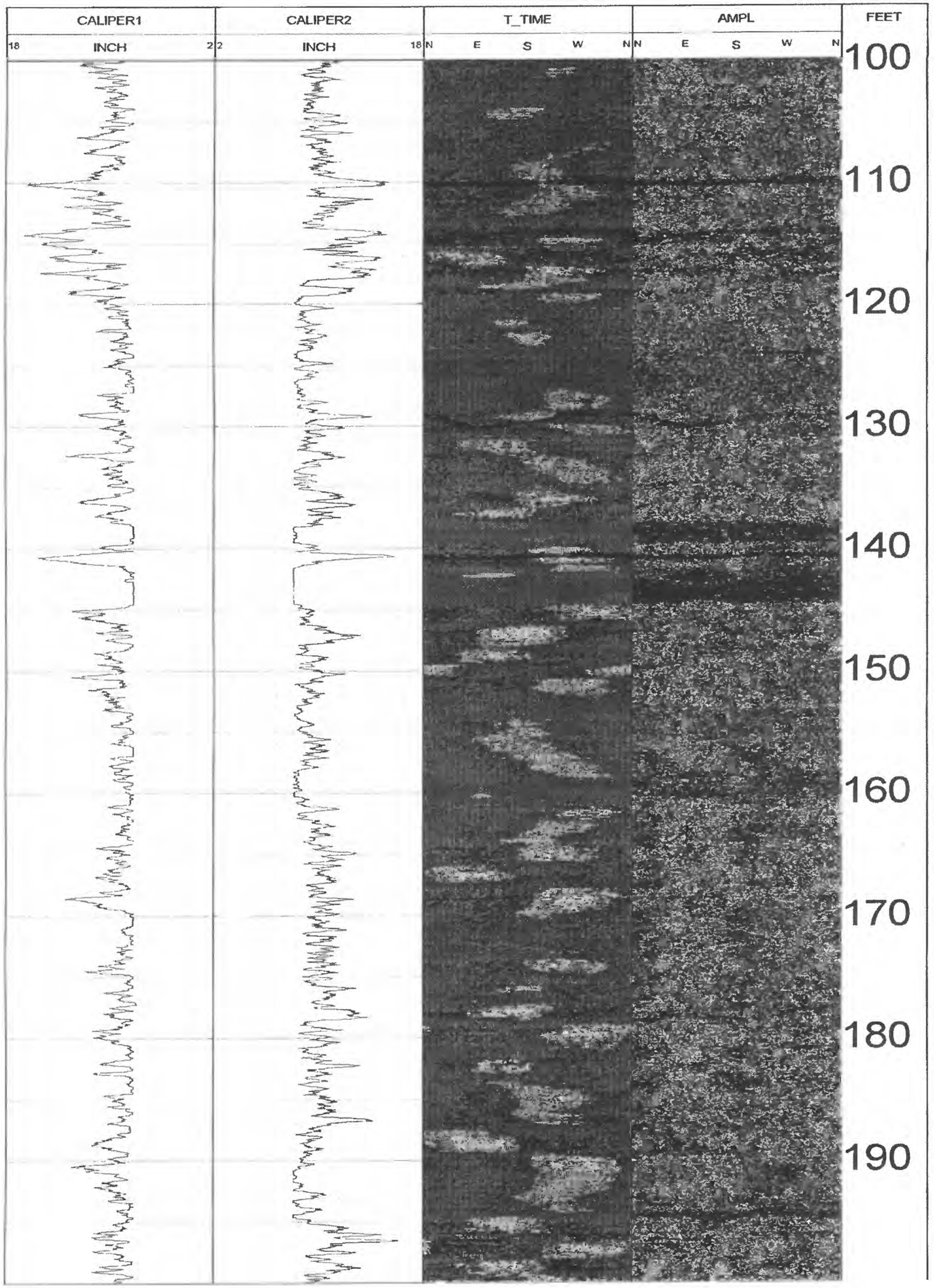


APPENDIX 1. ACOUSTIC TELEVIEWER LOG OF WELL W-4, RYE, NEW HAMPSHIRE--Continued

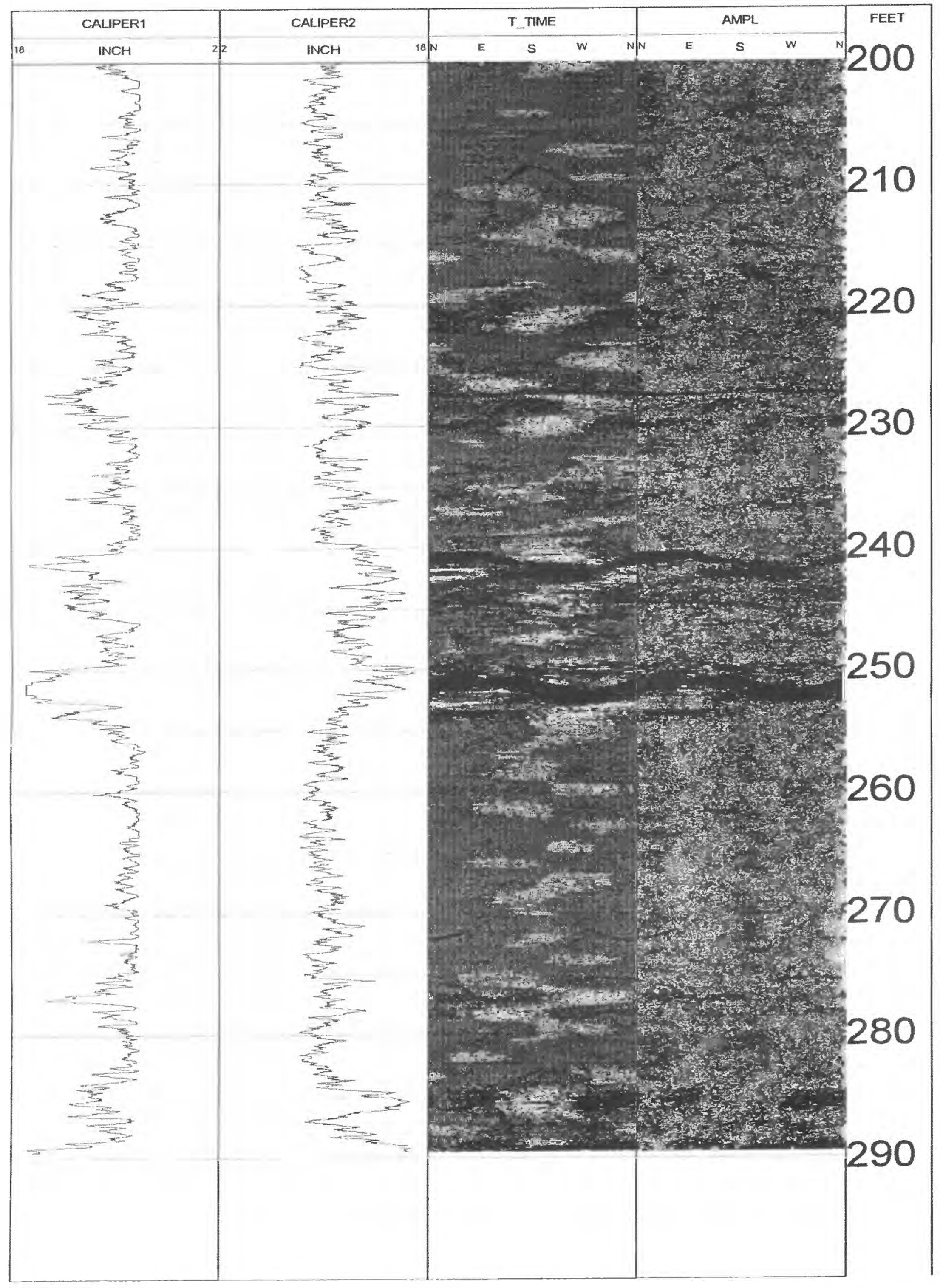


APPENDIX 1. ACOUSTIC TELEVIEWER LOG OF WELL W-5, RYE, NEW HAMPSHIRE

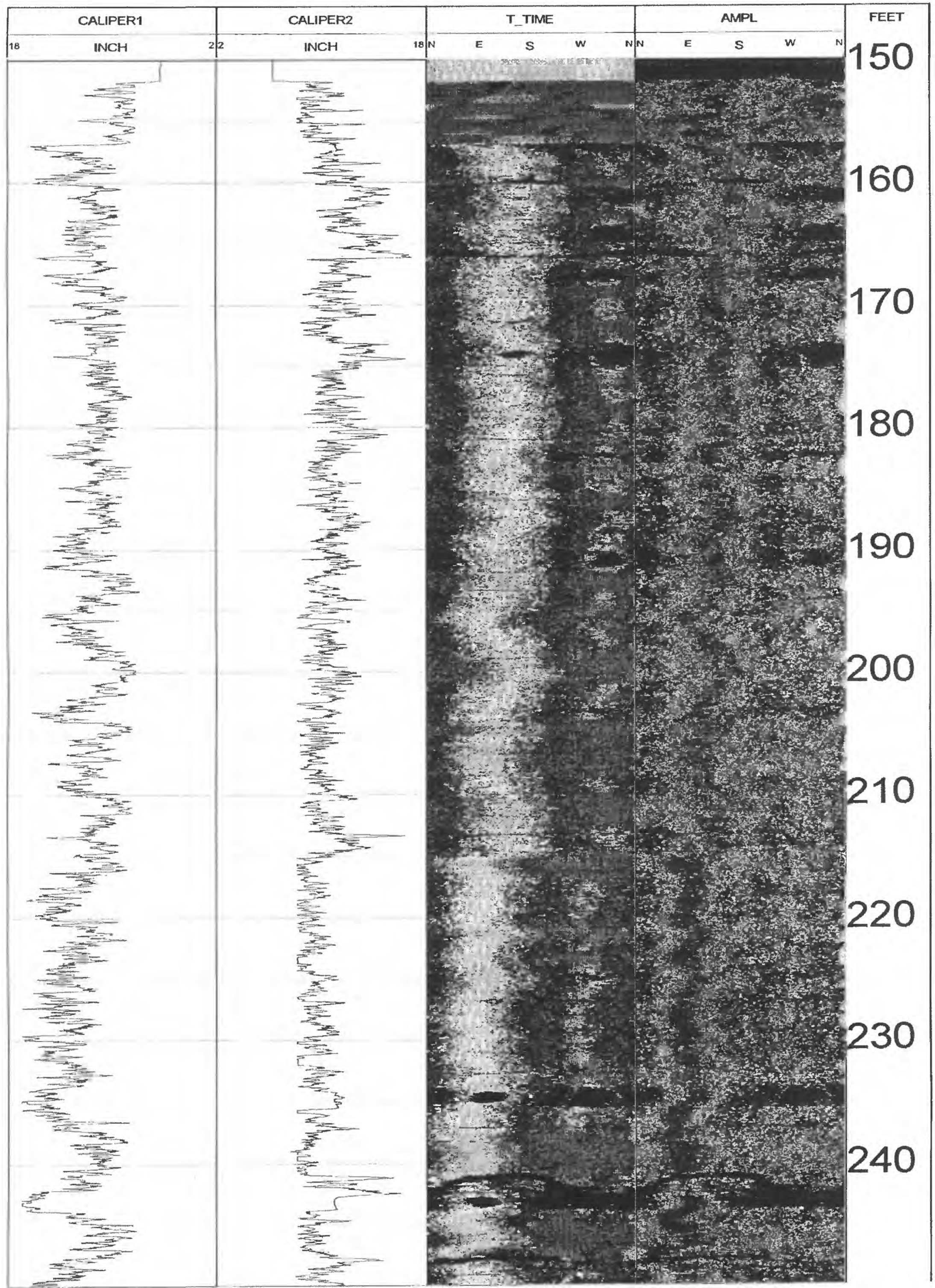


APPENDIX 1. ACOUSTIC TELEVIEWER LOG OF WELL W-5, RYE, NEW HAMPSHIRE--Continued

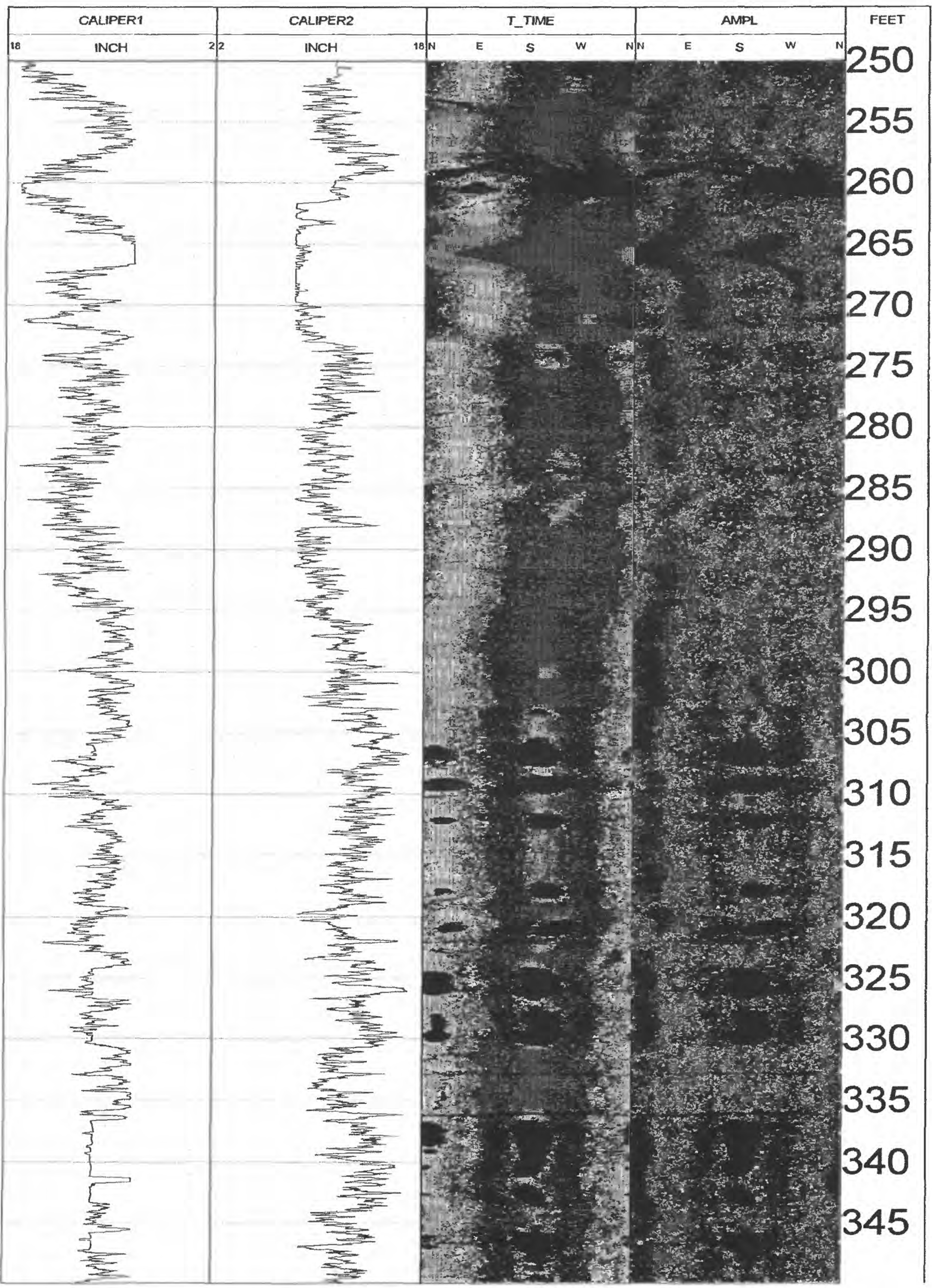


APPENDIX 1. ACOUSTIC TELEVIEWER LOG OF WELL W-5, RYE, NEW HAMPSHIRE--Continued

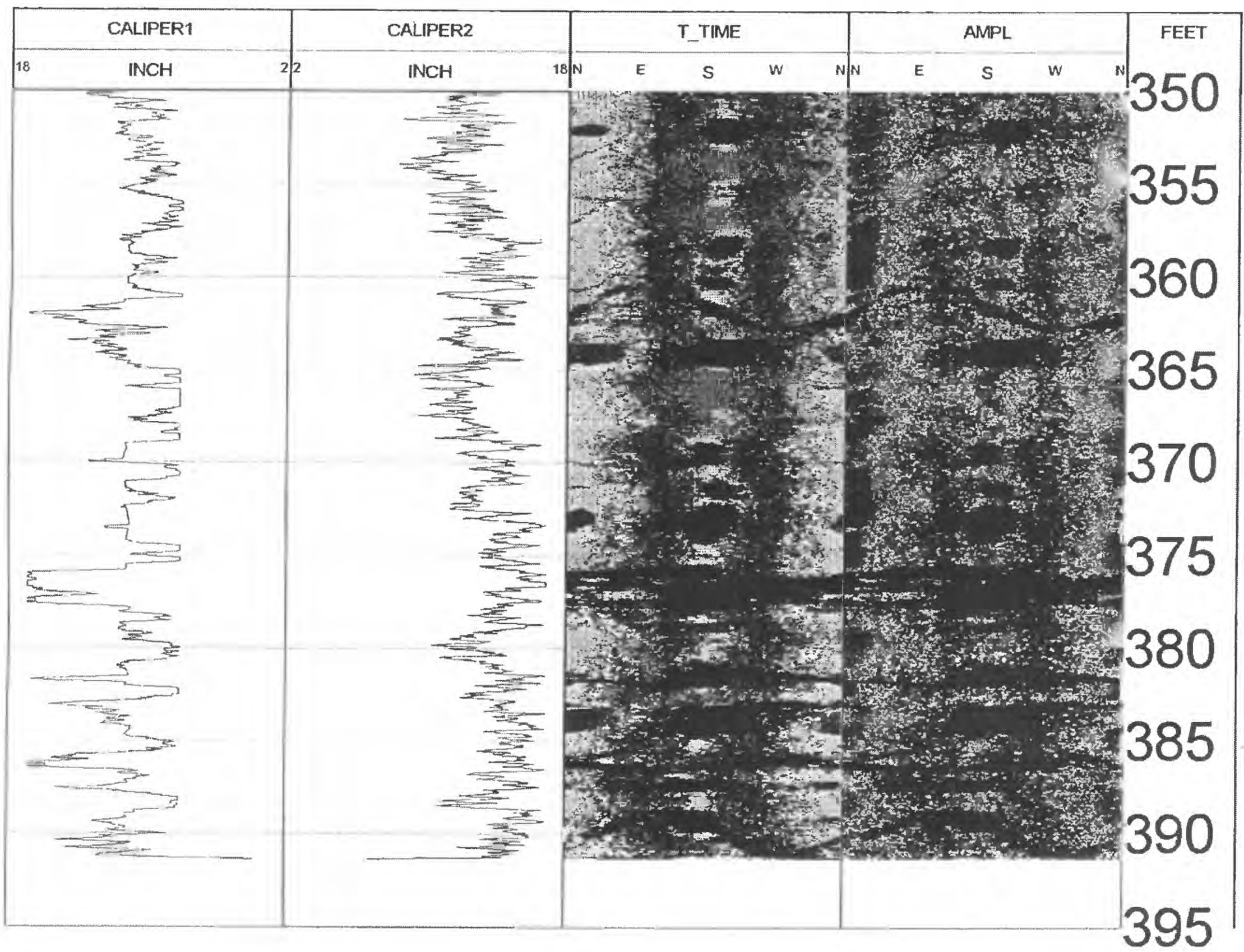


APPENDIX 1. ACOUSTIC TELEVIEWER LOG OF WELL TBR-1, RYE, NEW HAMPSHIRE

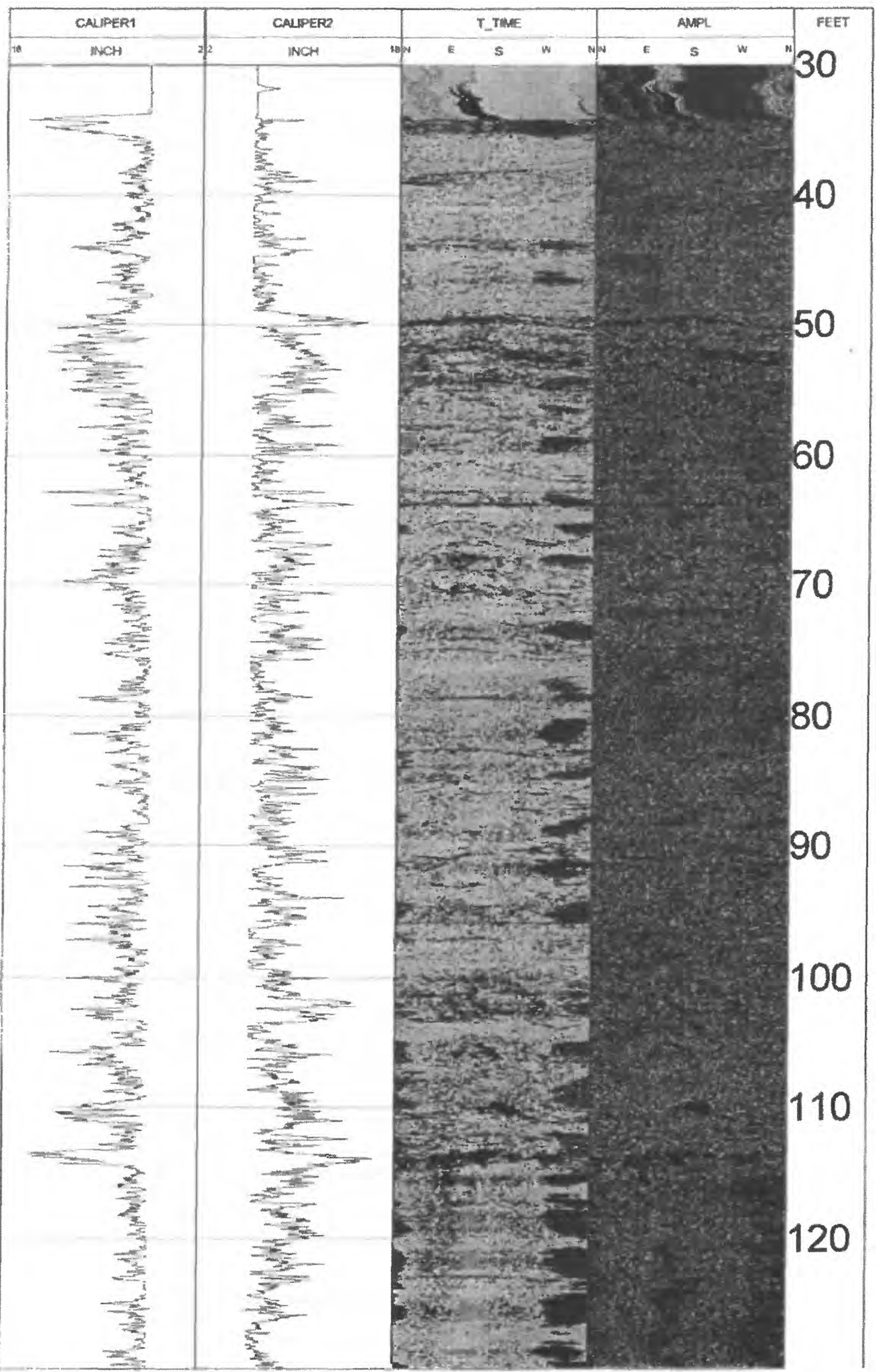


APPENDIX 1. ACOUSTIC TELEVIEWER LOG OF WELL TBR-1, RYE, NEW HAMPSHIRE--Continued

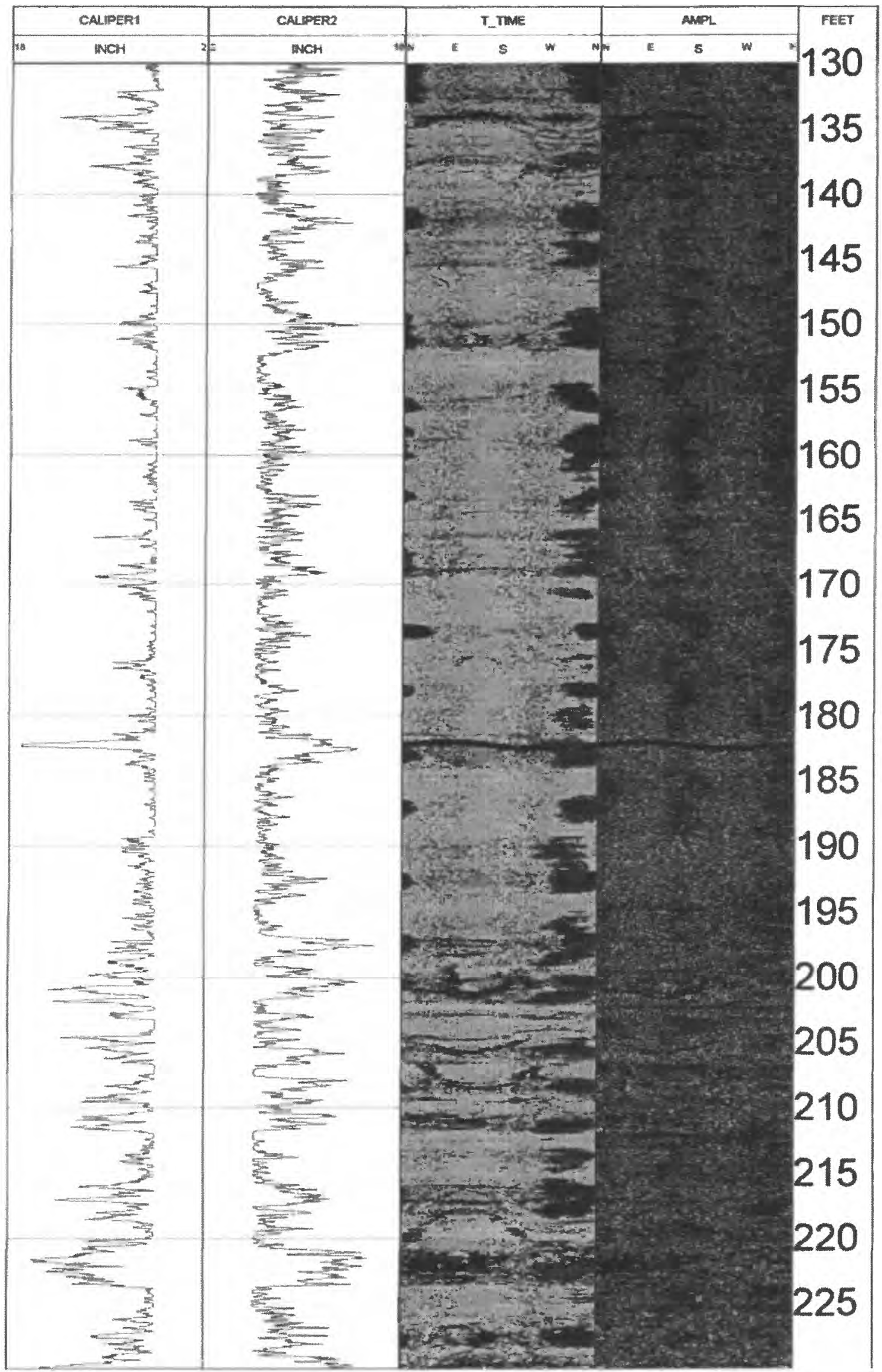


APPENDIX 1. ACOUSTIC TELEVIEWER LOG OF WELL TBR-1, RYE, NEW HAMPSHIRE--Continued




APPENDIX 1. ACOUSTIC TELEVIEWER LOG OF WELL TBR-2, RYE, NEW HAMPSHIRE

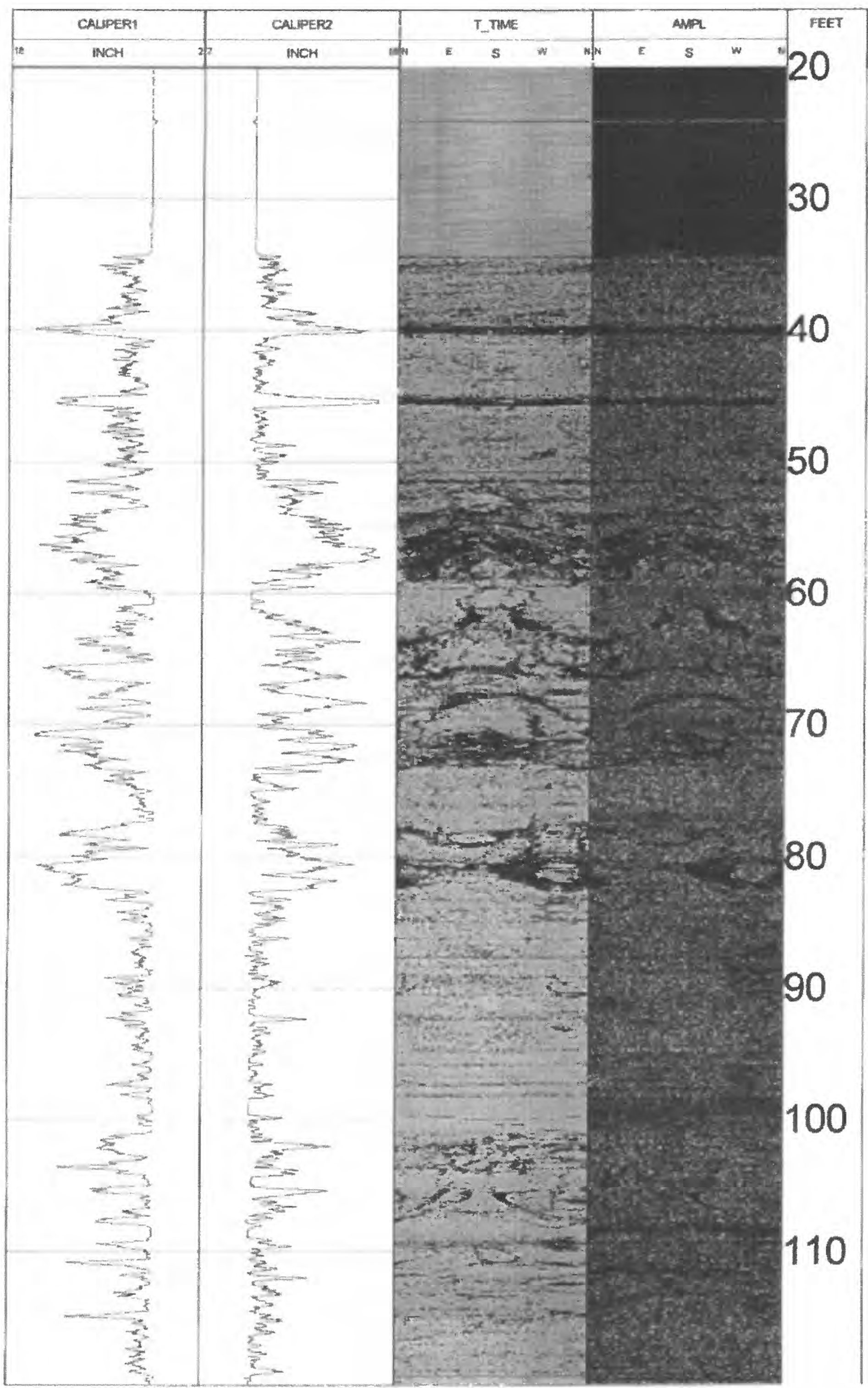


APPENDIX 1. ACOUSTIC TELEVIEWER LOG OF WELL TBR-2, RYE, NEW HAMPSHIRE--Continued

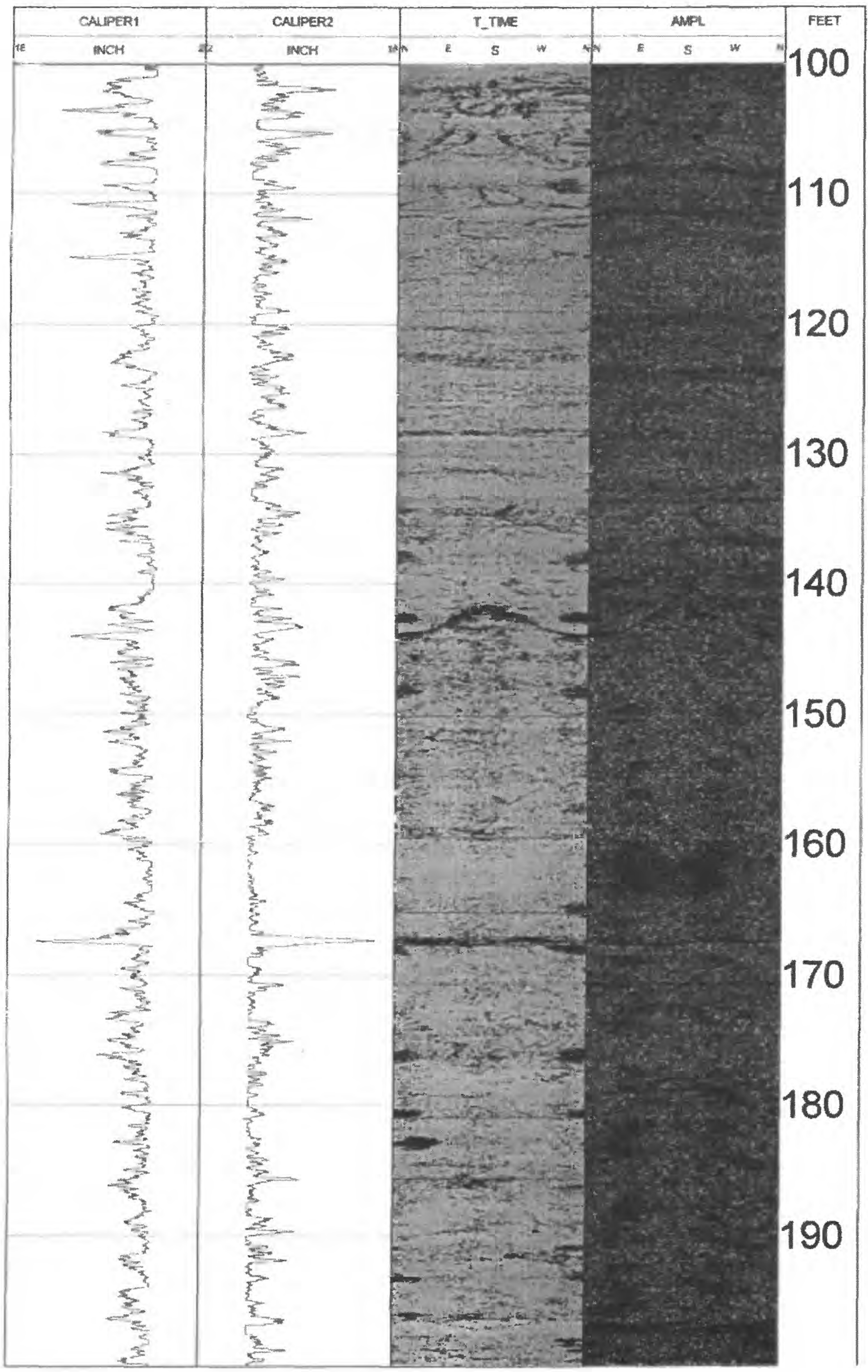


APPENDIX 1. ACOUSTIC TELEVIEWER LOG OF WELL TBR-2, RYE, NEW HAMPSHIRE--Continued

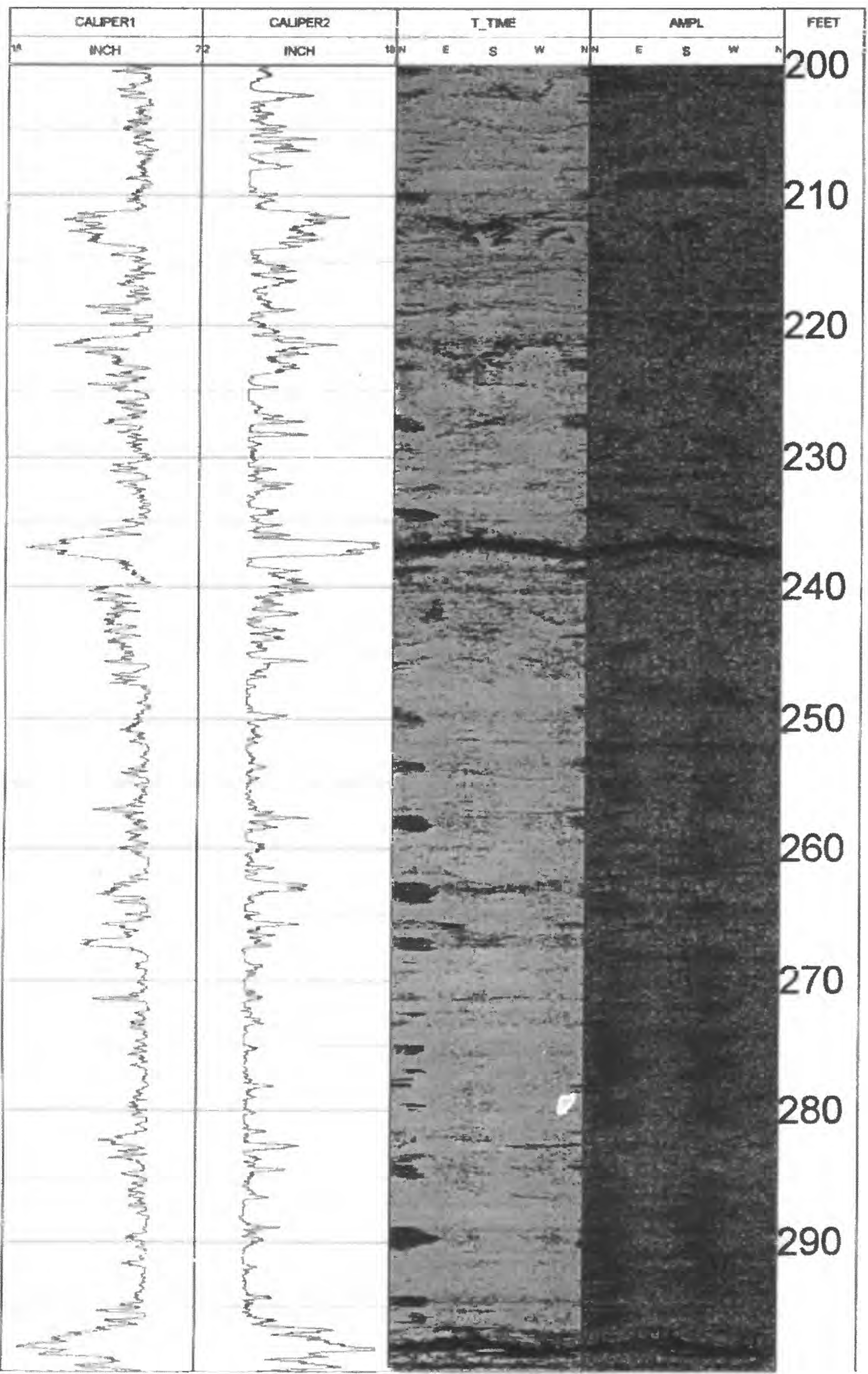


APPENDIX 1. ACOUSTIC TELEVIEWER LOG OF WELL TBR-2, RYE, NEW HAMPSHIRE--Continued

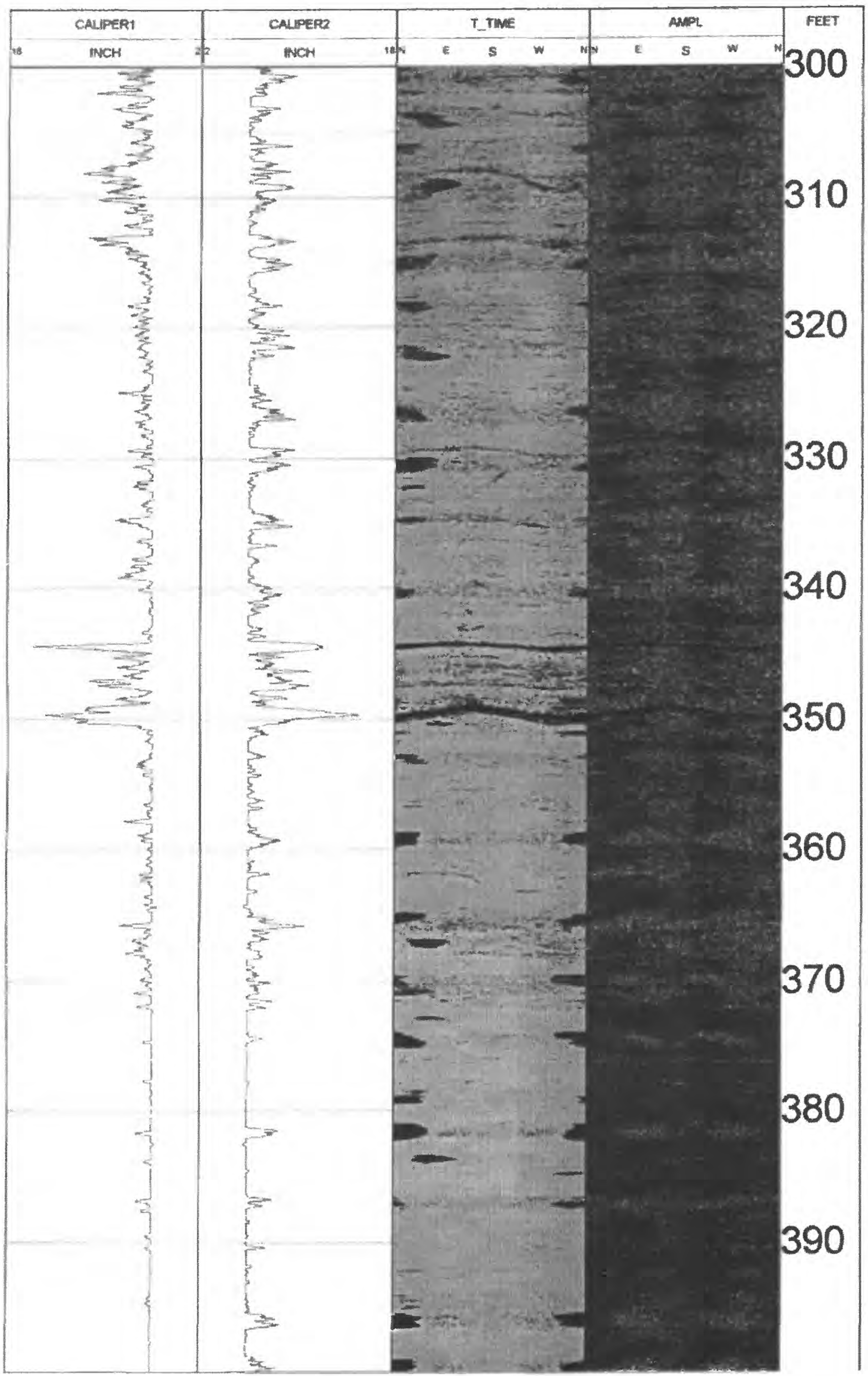


APPENDIX 1. ACOUSTIC TELEVIEWER LOG OF WELL TBR-3, RYE, NEW HAMPSHIRE

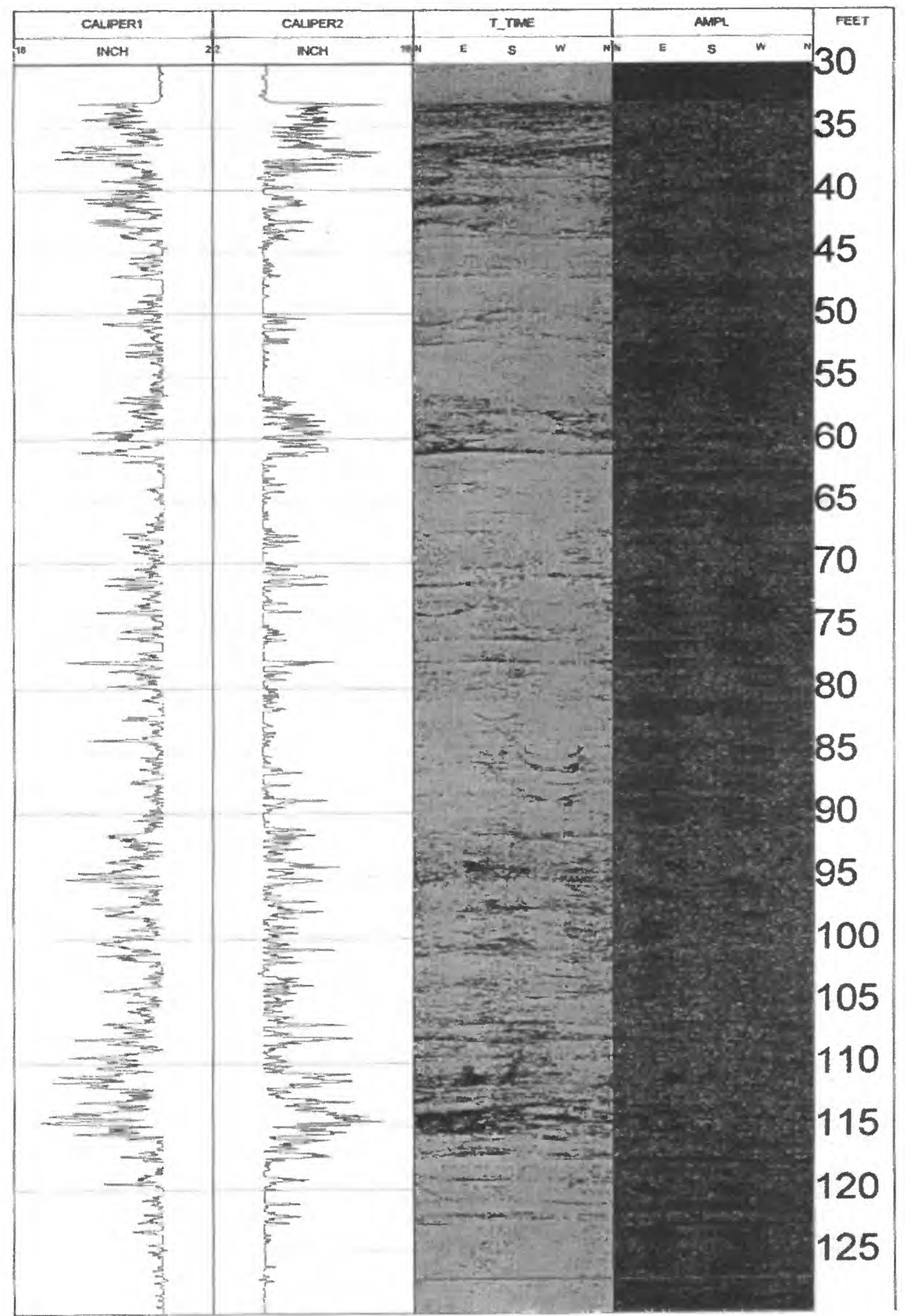


APPENDIX 1. ACOUSTIC TELEVIEWER LOG OF WELL TBR-3, RYE, NEW HAMPSHIRE--Continued

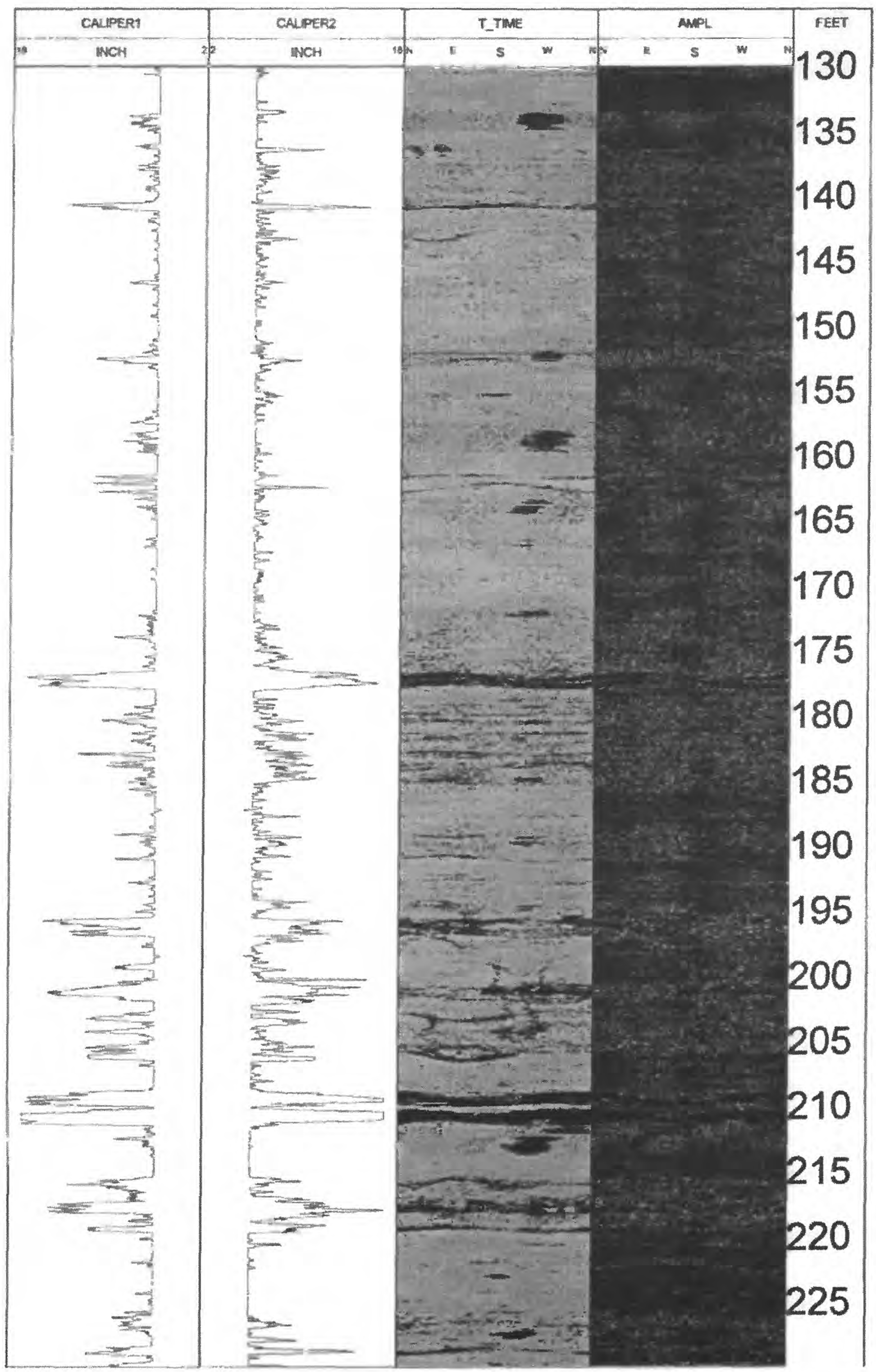


APPENDIX 1. ACOUSTIC TELEVIEWER LOG OF WELL TBR-3, RYE, NEW HAMPSHIRE--Continued

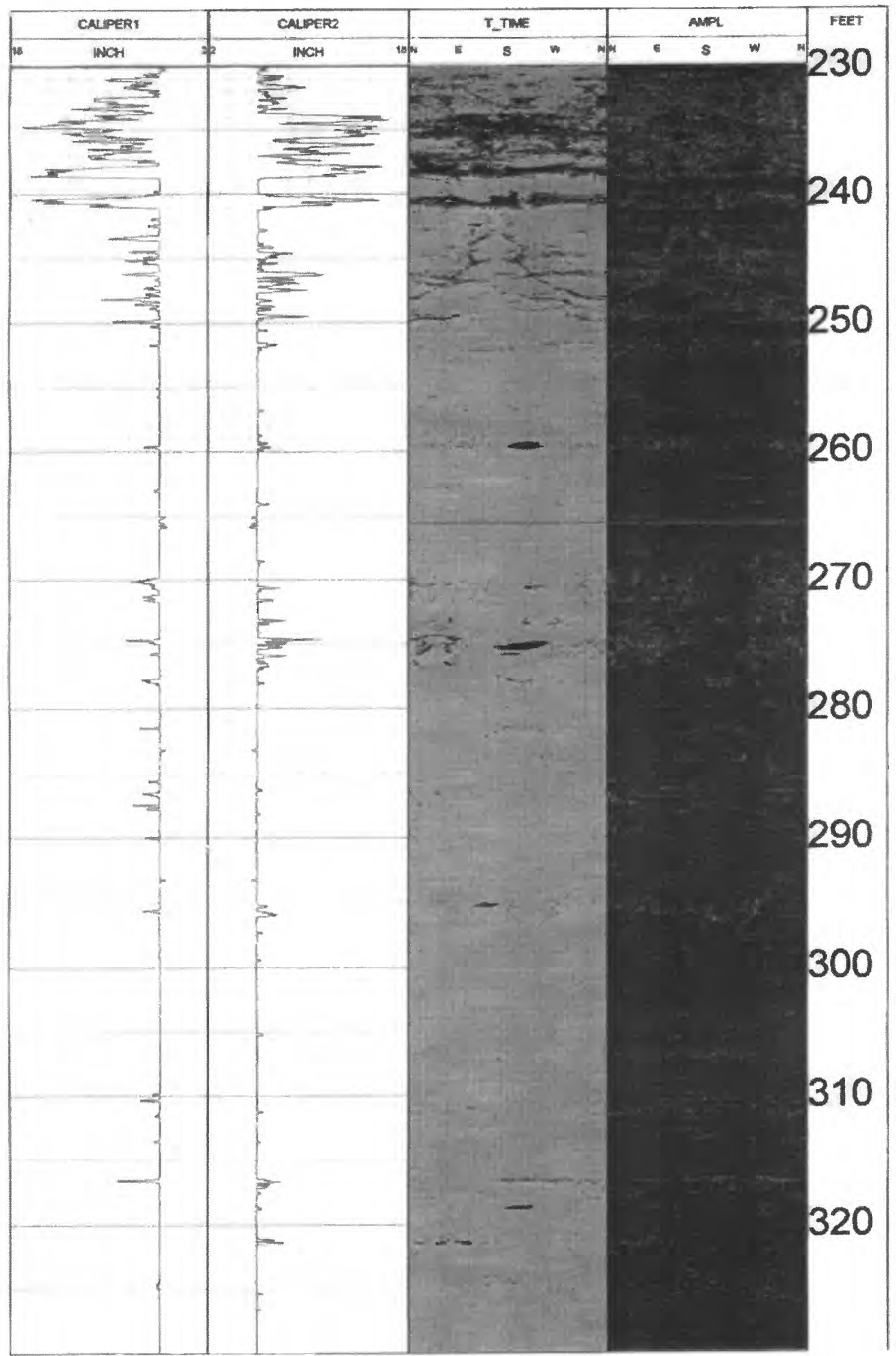


APPENDIX 1. ACOUSTIC TELEVIEWER LOG OF WELL TBR-3, RYE, NEW HAMPSHIRE--Continued

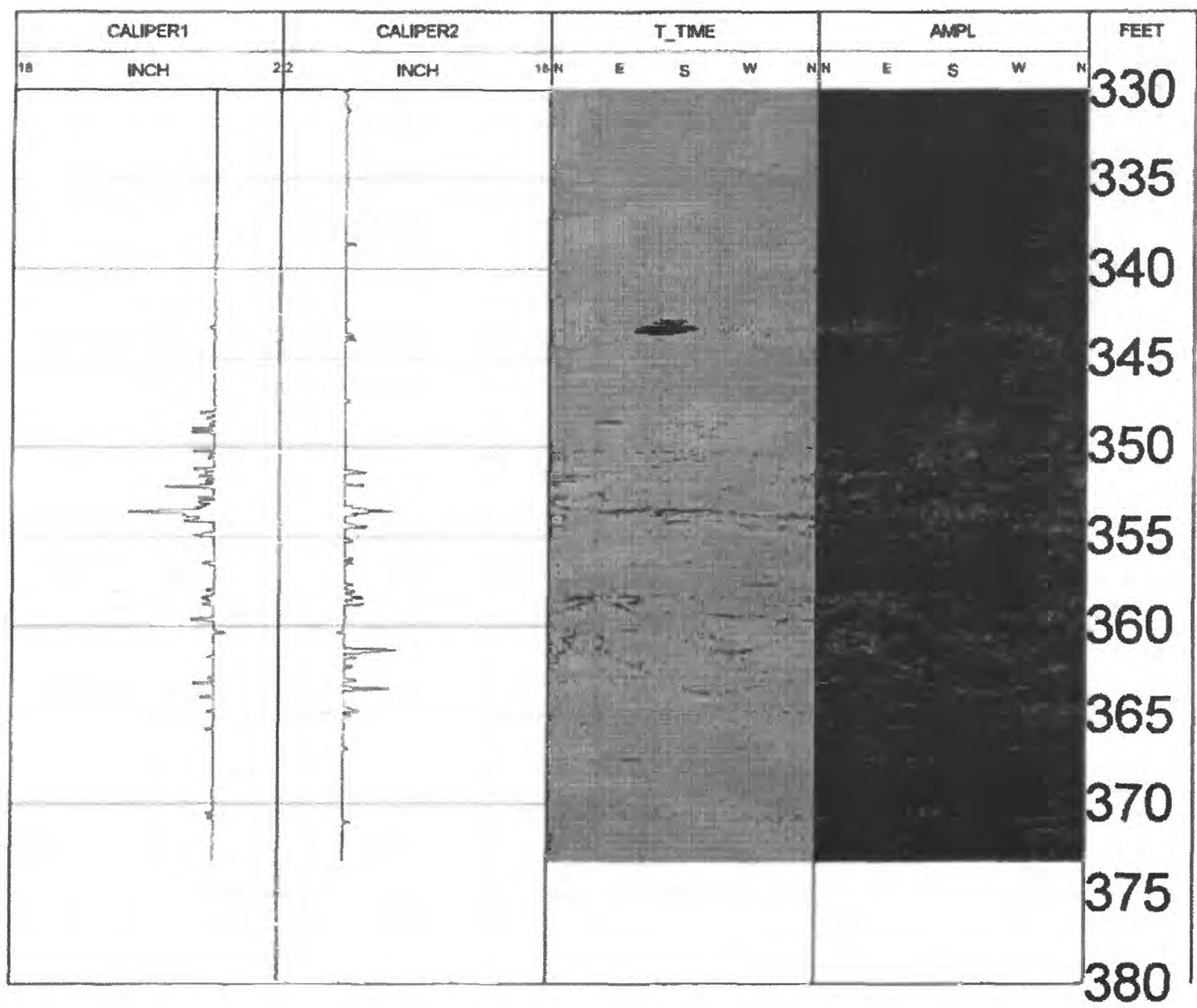

